\title{
"ESTUDO EPIDEMIOLÓGICO DE Rickettsia felis EM ÁREAS ENDÊMICAS E NÃO-ENDÊMICAS PARA FEBRE MACULOSA NO ESTADO DE SÃO PAULO"
}

Tese apresentada ao Programa de Pós-graduação em Epidemiologia Experimental e Aplicada às Zoonoses da Faculdade de Medicina Veterinária e Zootecnia da Universidade de São Paulo para obtenção do título de Doutor em Medicina Veterinária

\section{Departamento:}

Medicina Veterinária Preventiva e Saúde Animal

\section{Área de Concentração:}

Epidemiologia Experimental e Aplicada às Zoonoses

\section{Orientador:}

Profa. Dra. Teresinha Tizu Sato Schumaker 
Autorizo a reprodução parcial ou total desta obra, para fins acadêmicos, desde que citada a fonte.

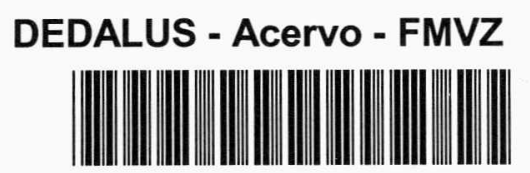

11300028730

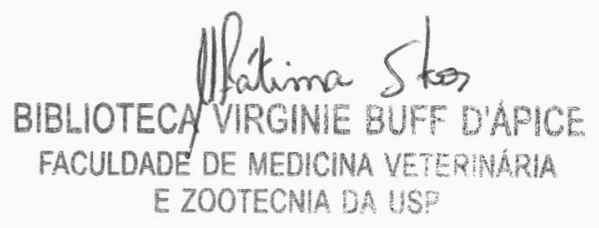

0510412006

\section{DADOS INTERNACIONAIS DE CATALOGAÇÃO-NA-PUBLICAÇÃO}

(Biblioteca Virginie Buff D’Ápice da Faculdade de Medicina Veterinária e Zootecnia da Universidade de São Paulo)

T. 1673

FMVZ
Horta, Maurício Claudio

Estudo epidemiológico de Rickettsia felis em áreas endêmicas e nãoendêmicas para febre maculosa no Estado de São Paulo / Maurício Claudio Horta. - São Paulo : M. C. Horta, 2006.

$106 \mathrm{f}$ : : il.

Tese (doutorado) - Universidade de São Paulo. Faculdade de Medicina Veterinária e Zootecnia. Departamento de Medicina Veterinária Preventiva e Saúde Animal, 2006.

Programa de Pós-graduação: Epidemiologia Experimental e Aplicada às Zoonoses.

Área de concentração: Epidemiologia Experimental e Aplicada às Zoonoses.

Orientador: Profa. Dra. Teresinha Tizu Sato Schumaker.
1. Rickettsia felis.
2. Pulga.
3. Febre maculosa.
4. Gambá. 


\section{UNIVERSIDADE DE SÃO PAULO \\ Faculdade de Medicina Veterinária e Zootecnia \\ Cidade Universitária "Armando de Salles Oliveira" \\ Comissão Bioética \\ CERTIFICADO}

Certificamos que o Projeto intitulado "Estudo epidemiológico de Rickettsia felis, espécie patogênica do grupo da febre maculosa, em áreas endêmicas e não-endêmicas do Estado de São Paulo" Protocolo n 301/2003, utilizando 60 gambás, 60 cães, 60 gatos e 60 cavalos, sob a responsabilidade da Prof ${ }^{a}$ Dr $^{\mathrm{a}}$ Teresinha Tizu Sato Schumaker, está de acordo com os princípios éticos de experimentação animal da Comissão de Bioética da Faculdade de Medicina Veterinária e Zootecnia da Universidade de São Paulo e foi aprovado "ad referendun".

(We certify that the Research "Epidemiologic survey of Rickettsia felis, a pathogenic spotted fever group Rickettsia, in endemic and non-endemic areas of São Paulo State" protocol number 301/2003, utilizing 60 opossums, 60 dogs, 60 cats and 60 horses, under the responsibility of $\operatorname{Prof}^{\mathrm{a}} \mathrm{Dr}^{\mathrm{a}}$ Teresinha Tizu Sato Schumaker, agree with Ethical Principles in Animal Research adopted by Biotic Commission of the Faculty of Veterinary Medicine and Zootechny of University of São Paulo and was approved "ad referendun").

São Paulo, 29 de abril de 2003

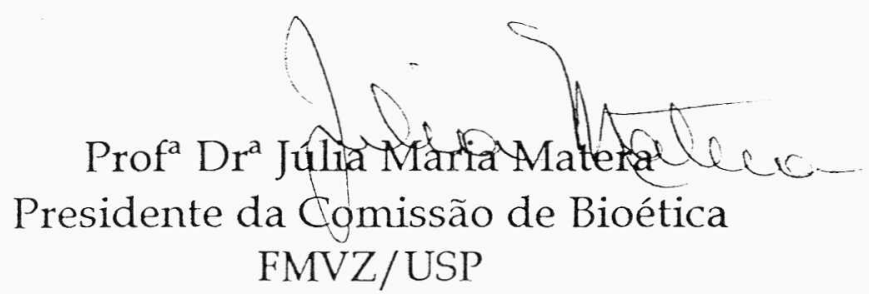




\section{PARECER 495/CEP}

São Paulo, 22 de agosto de 2003

Prezado Senhor,

Atendendo sua solicitação, a Comissão de Ética em Pesquisas com Seres Humanos do $I C B$, em sua trigésima oitava reunião, realizada no dia 19 de agosto p.p., analisou o projeto de sua responsabilidade intitulado:" Estudo Epidemiológico de Rickettsia felis, espécie patogênica do Grupo da Febre Maculosa, em áreas endêmicas e não endêmicas do Estado de São Paulo".

Informo que, após análise e discussão, o referido projeto, foi aprovado por esta Comissão.

Esclareço a V.Sa. que dentro de 12 meses, relatório do referido projeto deverá ser encaminhado à Secretaria deste CEP.

Atenciosamente,

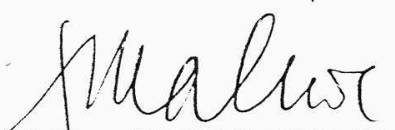

Prof. Dr. GERHARD MALNIC

Coordenador da Comissão de Ética em

Pesquisas dom Seres Humanos - ICB /USP

Ilmo. Sr.

MaURícIO CláUdio hORTA

Depto. de Medicina Veterinária Freventiva e Saúde Animal

Faculuade de Medicina Veieninária e Ruvecuid USr 
INSTITUTO BRASILEIRO DO MEIO AMBIENTE E DOS RECURSOS NATURAIS RENOVÁVEIS

DIRETORIA DE FAUNA E RECURSOS PESQUEIROS (DIFAP)

COORDENAÇÃO GERAL DE FAUNA (CGFAU)

ITAMA LICENÇA PARA CAPTURA/COLETA /TRANSPORTE

\begin{tabular}{|c|c|c|c|c|c|}
\hline \multicolumn{2}{|c|}{$\begin{array}{l}\text { NÚMERO DA LICENÇA } \\
0145 / 2004 \text { - CGFAU/LIC }\end{array}$} & $\begin{array}{c}\text { No DE REGISTRO NO IBAMA } \\
* * * * *\end{array}$ & $\begin{array}{r}\text { PERÍO } \\
11 / 08 / \\
\end{array}$ & $\begin{array}{l}\text { E VALIDADE } \\
11 / 08 / 2005\end{array}$ & $\begin{array}{l}\text { PROCESSO IBAMA } \\
02027.023912 / 2002\end{array}$ \\
\hline \multicolumn{4}{|c|}{ OBJETO: } & \multicolumn{2}{|c|}{ FAVORECIDO: } \\
\hline$x$ & \multicolumn{3}{|c|}{ CAPTURA E/OU COLETA DE ANIMAIS SILVESTRES/MATERIAL ZOOLÓGICO } & \multicolumn{2}{|c|}{-- zOOLÓGICO } \\
\hline$x$ & \multicolumn{3}{|c|}{ TRANSPORTE DE MATERIAL ZOOLÓGICO } & \multicolumn{2}{|c|}{ X INSTITUIÇÃO CIENTÍFICA } \\
\hline -. & \multicolumn{3}{|c|}{ COLETA E TRANSPORTE DE MATERIAL BOTÂNICO (PESQUISA CIENTIFICA) } & \multicolumn{2}{|c|}{$\mathbf{x}$ PESQUISADOR } \\
\hline-- & \multicolumn{3}{|c|}{ TRANSPORTE DE PRODUTOS E SUBPRODUTOS DA FAUNA } & \multicolumn{2}{|c|}{-- $\quad$ EXPOSITOR/CONCURSO } \\
\hline.- & \multicolumn{3}{|c|}{ EXPOSIÇÃO E/OU CONCURSO DE ANIMAIS SILVESTRES } & \multicolumn{2}{|c|}{-- $\quad$ CRIADOURO COMERCIAL } \\
\hline- & \multicolumn{3}{|c|}{ MANUTENÇÃO DE ANIMAIS EM CATTVEIRO } & \multirow{2}{*}{\multicolumn{2}{|c|}{-- CRIADOURO CIENTÍFICO }} \\
\hline-- & \multicolumn{3}{|l|}{ OUTROS: } & & OUTROS: \\
\hline
\end{tabular}

\section{FAVORECIDOS}

NOME(S): Maurício Cláudio Horta e Teresinha Tizu Sato Schumaker.

INSTITUIÇÃO: Universidade de São Paulo, Faculdade de Medicina Veterinária e Zootecnia, Departamento de Medicina Veterinária Preventiva e Saúde Animal.

ENDEREÇO: Universidade de São Paulo, Av. Prof. Dr. Orlando Marques de Paiva, 87, Cidade Universitária, São Paulo, SP, 05508-000

RESPONSÁVEL PELA EXPEDIÇÃO: Teresinha Tizu Sato Schumaker.

TRANSPORTADOR: Os pesquisadores favorecidos.

MEIO DE TRANSPORTE: Terrestre / Aéreo.

PROCEDÊNCIA/LOCAL DA CAPTURA/LOCAL DA PESQUISA: Estado de São Paulo.

DESTINO DO MATERIAL: Universidade de São Paulo, Faculdade de Medicina Veterináría e Zootetnia, Departamento de Medicina Veterinária Preventiva e Saúde Animal.

\begin{tabular}{c|c|c|}
\hline $\begin{array}{c}\text { LISTA DAS ESPECIES } \\
\text { QUANTIDADE / TIPO }\end{array}$ & NOME CIENTÍfICO & NOME COMUMAUNA \\
\hline $\begin{array}{c}\text { Captura, seguida de soltura, para marcação e } \\
\text { coleta de sangue e ectoparasitas } \\
60 \text { (sessenta) espécimes }\end{array}$ & Didelphis sp. \\
\hline
\end{tabular}

\section{OBSERVAÇÕES E CONDICIONANTES:}

1. O responsável pela expedição deverá apresentar relatório de atividades ao término da validade desta licença.

2. O responsável pela expedição deverá encaminhar ao Ibama cópia dos frontispícios das publicações resultantes dos trabalhos decorrentes do uso dos espécimes objeto desta licença.

3. Esta licença não exime o pesquisador de cumprir o disposto na Medida Provisória $N^{\circ} 2186-16 / 01$ que dispõe sobre o acesso ao patrimônio genético. No caso de acesso ao componente do patrimônio genético, ests somente se dará mediante a autorização do Ibama, nos termos da Medida Provisória n 2.186-16/2001 e Decretos no 3.945/2001 e $n^{\circ} 4.946 / 2003$.

\section{LOCAL E DATA DE EMISSÃO}

Brasília (DF), 11 de agosto de 2004.

- ESTA LICENÇA NÃO AUTORIZA:

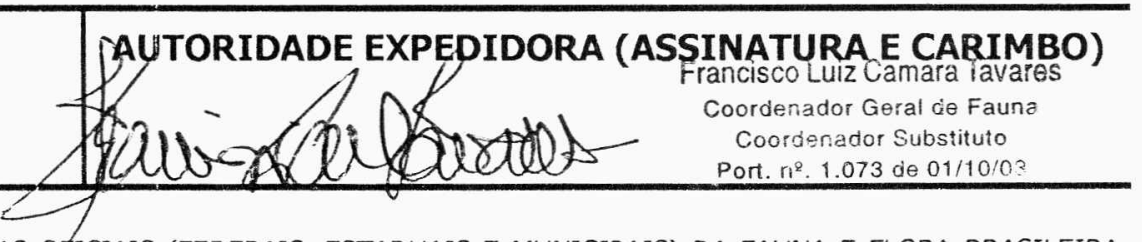

CAPTURA DE ESPÉCIES QUE CONSTEM NAS LISTAS OFICIAIS (FEDERAIS, ESTADUAIS E MUNICIPAIS) DA FAUNA E FLORA BRASILEIRA AMEAÇADAS DE EXTINÇÃO, ESPÉCIES ENDÊMICAS OU RARAS, OU QUE CONSTEM NOS ANEXOS I DA CONVENÇÃO SOBRE O COMÉRCIO INTERNACIONAL DE ESPÉCIES DA FAUNA E DA FLORA AMEAÇADAS DE EXTINÇÃO (CITES), SALVO QUANDO ESPECIFICADO;

CAPTURA, COLETA E OU TRANSPORTE DE ESPÉCIMES DA FAUNA NAS ÁREAS DE INFLUENNCIA DE EMPREENDIMENTOS SUJEITOS AO LICENCIAMENTO AMBIENTAL, CONFORME RESOLUÇAO DO CONAMA DE NO 237 DE 19/12/97, SALVO QUANDO ESPECIFICADO.

CAPTURA DOS ESPÉCIMES DA FAUNA EM ÁREAS DE DOMÍNIO PRIVADO, SEM O CONSENTIMENTO DO PROPRIETÁRIO, ARRENDATÁRIO, POSSEIRO OU MORADOR DA ÁREA;

CAPTURA, COLETA E OU TRANSPORTE DE ESPÉCIMES FAUNA EM UNIDADES DE CONSERVAÇÃO FEDERAIS, ESTADUAIS, DISTRITAIS OU MUNICIPAIS, SALVO QUANDO ACOMPANHADAS DO CONSENTIMENTO DO ÓRGÃO ADMINISTRADOR COMPETENTE;

5. EXPORTAÇÃO DE MATERIAL ZOOLÓGICO OU REMESSA (PARA O EXTERIOR) DE AMOSTRA DE COMPONENTE DO PATRIMÔNIO GENÉTICO.

- SÃO ISENTAS DE COBRANÇA DE TAXA (RECOLHIMENTO DE DR) INSTITUIÇÕES CIENTÍFICAS, PESQUISADORES E ZOOLÓGICOS PÚBLICOS.

- VÁLIDA SOMENTE SEM EMENDAS OU RASURAS 
Nome: HORTA, Maurício Claudio

Título: Estudo epidemiológico de Rickettsia felis em áreas endêmicas e nãoendêmicas para febre maculosa no Estado de São Paulo

Tese apresentada ao Programa de Pós-graduação em Epidemiologia Experimental e Aplicada às Zoonoses da Faculdade de Medicina Veterinária e Zootecnia da Universidade de São Paulo para obtenção do título de Doutor em Medicina Veterinária

Data:

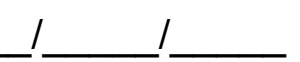

Banca Examinadora

Prof. Dr. Instituição:

Assinatura: Julgamento:

Prof. Dr. Instituição:

Assinatura: Julgamento:

Prof. Dr. Instituição:

Assinatura: Julgamento:

Prof. Dr. Instituição:

Assinatura: Julgamento:

Prof. Dr. Instituição:

Assinatura: Julgamento: 


\section{DEDICATÓRIA}

Dedico este trabalho:

Aos meus pais,

Ivone Claudio Horta;

Rubens Horta (in memorian).

Aos meus irmãos,

Silvia Cristina Horta de Almeida,

Sandra Regina Horta Cardoso,

Sérgio Luis Horta,

Ana Paula Claudio Horta.

Sem eles, nada seria possível... 
$\checkmark$ A Teresinha Tizu Sato Schumaker, pela orientação, paciência, compreensão e amizade depositadas em mim durante todos esses anos de convivência.

$\checkmark$ Ao Marcelo Bahia Labruna, pela co-orientação, amizade, ensinamentos e incentivo durante todos os momentos da pesquisa.

$\checkmark$ À Solange Maria Gennari, pelo reconhecimento, auxílio e confiança.

$\checkmark$ Ao Fernando Ferreira, pela contribuição na discussão do trabalho e análise estatística dos resultados.

$\checkmark$ Ao Fábio Gregori e Paulo Eduardo Brandão pela contribuição no trabalho, principalmente pelas sugestões na ocasião da qualificação.

$\checkmark$ Ao prof. Pedro Marcos Linardi, pelo auxílio, principalmente em relação à identificação das pulgas.

$\checkmark$ Ao prof. Edison Luiz Durigon e seus alunos, Dyana e Fábio, pelo fornecimento das células $\mathrm{C6/36}$, fundamentais para o sucesso deste trabalho.

$\checkmark$ Aos profs. Gilberto José de Morais e Luciano Verdade, pelo apoio durante o trabalho de campo em Piracicaba.

$\checkmark$ Ao prof. Leonardo Richtzenhain, responsável pelo laboratório de biologia molecular, onde parte da pesquisa foi desenvolvida.

$\checkmark$ Ao prof. Rodrigo Martins Soares, pelo apoio técnico e científico.

$\checkmark$ Ao prof. Luiz Jacintho da Silva (UNICAMP), pelo apoio científico. 
$\checkmark$ Ao Celso Eduardo Souza e Elias José Rodrigues Neto (SUCEN), pelo fornecimento de soro positivo de gambá, utilizado nas RIFIs.

$\checkmark$ Aos bons samaritanos que me ajudaram nas colheitas de materiais a campo: Adriano Pinter, Alexandre Ataliba, Maria Cristina Bataglioli, Daniel Aguiar, Marcelo Nardi, Patrícia Bertola, Paula Martin.

$\checkmark$ Às enfermeiras e técnicas de enfermagem que auxiliaram na colheita de sangue das pessoas: Eneide Maria Bonaldo (Pedreira); Marisa Vicente da Silva Lopes (Piracicaba), Isabel Luiza de Faria Cid (Mogi das Cruzes), Fabiana Monteiro Macatrozzo (Pirassununga) e Daniele Cardoso Carrasco (São Paulo).

$\checkmark$ À Hilda Pena, pela ajuda, apoio e documentação fotográfica.

$\checkmark$ À equipe do Laboratório de Sequenciamento de DNA (ICB2), Fabiana Cristina Pereira dos Santos, Camila, Juncansen, Daniele Barbosa de Souza, Fernanda Christtanini Koyama.

$\checkmark$ Aos amigos Adriano Pinter, Daniel Moura de Aguiar, Richard de Campos Pacheco, Ricardo Cabrera, Alexandre Ataliba, lara Silveira; do Laboratório de Doenças Parasitárias II (Carrapatos), cuja convivência harmoniosa foi fundamental não só para a conclusão dos trabalhos práticos, como também para a manutenção da minha saúde física e mental.

$\checkmark$ Ao grupo "Neospora", do Laboratório de Doenças Parasitárias I: Alessandra Ragozzo, Aline Rodrigues, Renata Moreira, Silvio Pereira e Tatiana Ueno.

$\checkmark$ Às minhas amigas: Patrícia Marques Ferreira, pela assessoria em assuntos aleatórios; Daniela Pontes Chiebao, pelo interesse e ajuda nos trabalhos práticos; Renata Paixão, pela paciência e ajuda na fase final do trabalho. 
$\checkmark$ À equipe de apoio na cidade de Pedreira/SP: Maria Rita do Nascimento Rodrigues, Maria Cristina Bataglioli, Lilia Gouveia Teixeira Pires, Nadir Perin.

$\checkmark$ Aos proprietários e moradores das propriedades onde foram realizadas as pesquisas de campo: Eduardo Pupo, Elza Pessoti Sartori, Jorge Andre Ferreira (Pedreira), Domingos Rocco (Mogi das Cruzes).

$\checkmark$ À Prefeitura do Campus da ESALQ/USP, na pessoa do prefeito Marcos Folegatti, que apoiou parte do projeto desenvolvido em Piracicaba.

$\checkmark$ À equipe de apoio na cidade de Piracicaba: Lázaro, Paula S. Martin.

$\checkmark$ À Prefeitura Campus de Pirassununga.

$\checkmark$ À equipe de apoio na cidade de São Paulo: Eudina Barata (SUCEN), Andrea Podolski (Bicho no Parque), Silvio Luis França, Keiko Ichi Silveira (SESC-Interlagos).

$\checkmark$ A Maria Eugênia Summa, Francis Rossi, Vilma Geraldi e Adriana Joppert (DEPAVE/SP), pelo auxílio na manipulação e colheita de sangue dos gambás.

$\checkmark$ A Elza Faquim pela atenção e revisão do volume final na biblioteca.

$\checkmark$ Às pessoas que, voluntariamente, doaram seu sangue e contribuíram para os avanços da pesquisa da febre maculosa brasileira.

$\checkmark$ Aos animais que participaram desse projeto, que, mesmo contra vontade, cederam materiais biológicos para a pesquisa.

$\checkmark$ À FAPESP - Processos 02/10759-0 e 03/04728-7, pelo auxílio financeiro. 
HORTA, M. C. Estudo epidemiológico de Rickettsia felis em áreas endêmicas e não-endêmicas para febre maculosa no Estado de São Paulo. [Epidemiologic study of Rickettsia felis in endemic and non-endemic areas for spotted fever in the State of São Paulo]. 2006. $106 \mathrm{f}$. Tese (Doutorado em Medicina Veterinária) Faculdade de Medicina Veterinária e Zootecnia, Universidade de São Paulo, São Paulo, 2006.

Estudos recentes demonstraram a existência de Rickettsia felis, riquétsia do Grupo da Febre Maculosa, em sangue de pacientes com quadro clínico compatível com a doença e em pulgas infectadas. Este projeto visa determinar a prevalência de $R$. felis em vetores (pulgas e carrapatos) e em potenciais reservatórios (gambás, cães, gatos, eqüinos e humanos), procedentes de áreas endêmicas (Mogi das Cruzes, Pedreira, Piracicaba e São Paulo), e não endêmicas (Pirassununga) para FM no Estado de São Paulo. Foram utilizados métodos moleculares (reação em cadeia pela polimerase e sequenciamento de DNA), diagnóstico sorológico e cultivo celular. Em gambás capturados (Didelphis aurita e Didelphis albiventris) foram colhidas 312 pulgas, pertencentes às Famílias Pulicidae (141), Rhopalopsyllidae (170) e Ctenophthalmidae (1) e 709 carrapatos (Amblyomma spp e Ixodes loricatus). Nos cães foram colhidos 212 pulgas (Ctenocephalides felis felis) e 115 carrapatos (Amblyomma cajennense, Amblyomma aureolatum e Rhipicephalus sanguineus). Nos gatos foram colhidos 66 pulgas (59 C. felis felis e 7 Rhopalopsyllus lutzi lutzi) e 10 carrapatos ( $R$. sanguineus e Amblyomma spp). A colheita de sangue foi realizada em 94 gambás, 55 cães, 25 gatos, 85 eqüinos e 238 humanos. Rickettsia felis foi detectada em $42-45,8 \%$ das pulgas C. felis felis de gambás, cães e gatos; em $4 \%$ das pulgas Polygenis $(N)$ atopus de gambás e em $1,8 \%$ e $0,7 \%$ de carrapatos I. Ioricatus e Amblyomma spp, respectivamente, colhidos de gambás. Rickettsia bellii foi detectada em carrapatos I. loricatus (59,1\%), A. dubitatum $(8,7 \%)$ e Amblyomma spp $(0,9 \%)$ e em uma pulga $P$. (N.) atopus (1\%). Não foi possível a detecção de infecção por Rickettsia spp em sangue dos animais e humanos. Contudo, constatou-se presença anticorpos frente aos antígenos de Rickettsia rickettsii, Rickttesia parkeri, $R$. felis e $R$. bellii nas áreas estudadas. A titulação obtida sugere infecção por $R$. rickettsii em gambás, cães, eqüinos e humanos e por $R$. parkeri em gambás, cães e eqüinos. $R$. felis e $R$. bellii foram isoladas e cultivadas com a utilização de células $C 6 / 36$ e VERO, respectivamente.

Palavras-chave: Rickettsia felis. Febre maculosa. Gambá. Pulga. Carrapatos. 
HORTA, M. C. Epidemiologic study of Rickettsia felis in endemic and nonendemic areas for spotted fever in the State of São Paulo. [Estudo epidemiológico de Rickettsia felis em áreas endêmicas e não-endêmicas para febre maculosa no Estado de São Paulo]. 2006. 106 f. Tese (Doutorado em Medicina Veterinária) - Faculdade de Medicina Veterinária e Zootecnia, Universidade de São Paulo, São Paulo, 2006.

Recent studies have showed the presence of Rickettsia felis, a spotted fever group Rickettsiae, in human blood with clinical signs compatible with spotted fever and in infected fleas. This work aims to determine the prevalence of $R$. felis in potential vectors (fleas and ticks) and reservoirs (opossums, dogs, cats, equines and humans) from endemic (Mogi das Cruzes, Pedreira, Piracicaba e São Paulo), and non-endemic (Pirassununga) areas for spotted fever in the State of São Paulo. Molecular probes (polimerase chain reaction and DNA sequencing), serologic diagnoses and cell culture were used. From trapped opossums (Didelphis aurita and Didelphis albiventris) a total of 312 fleas, belonging to Family Pulicidae (141), Rhopalopsyllidae (170) and Ctenophthalmidae (1) and 709 ticks (Amblyomma spp and Ixodes loricatus) were collected. On dogs a total of 212 fleas (Ctenocephalides felis felis) and 115 ticks (Amblyomma cajennense, Amblyomma aureolatum and Rhipicephalus sanguineus) were collected. On cats, 66 fleas (59 C. felis felis and 7 Rhopalopsyllus lutzi lutzi) and 10 ticks ( $R$. sanguineus and Amblyomma spp) were collected. Blood samples were collected from 94 opossums, 55 dogs, 25 cats, 85 equines and 238 humans. Rickettsia felis was detected in $42-45,8 \%$ of the $C$. felis felis collected on opossums, dogs and cats. This same Rickettsia species was detected in $4 \%$ of Polygenis (N.) atopus fleas, and $1,8 \%$ and $0,7 \%$ of I. Ioricatus and Amblyomma spp ticks, respectively, collected from opossums. Rickettsia bellii was found in ticks I. Ioricatus (59,1\%), A. dubitatum (8,7\%) and Amblyomma spp (0,9\%) and in a flea $P$. (N.) atopus (1\%). No Rickettsia DNA was detected in animal or human blood samples. However antibodies against Rickettsia rickettsii, Rickettsia parkeri, $R$. felis and $R$. bellii were detected in all locations. The titers suggest infection by $R$. rickettsii in opossums, dogs, equines and humans and by $R$. parkeri in opossums, dogs and equines. $R$. felis and $R$. bellii were isolated and cultivated with the C6/36 and VERO cells, respectively.

Key words: Rickettsia felis. Spotted fever. Opossum. Flea. Ticks. 


\section{\# FIGURAS}

Figura 1 - Distribuição dos casos e febre maculosa no Estado de São Paulo: 1985-2005. CVE, 2006. Em destaque: áreas de estudos: (a) Pedreira, (b) Piracicaba, (c) Mogi das Cruzes, (d) São Paulo, (e) Pirassununga 31

Figura 2 - Sítios de Colheita: (a) Pedreira, (b) Piracicaba, (c) Mogi das Cruzes, (d) São Paulo, (e) Pirassununga ................................................. 33

Figura 3 - (a) Didelphis aurita (gambá de orelha preta). Pedreira/SP - 2004; (b) Didelphis albiventris (gambá de orelha branca). Piracicaba/SP - 2003

Figura 4 - Soro de gambá reagente ao antígeno de $R$. felis na reação de imunofluorescência indireta 56

Figura 5 - (a), (b) células C6/36 infectadas com Rickettsia felis cepa PEDREIRA, coradas com fucsina e verde malaquita; (c), (d) células VERO infectadas com $R$. bellii cepa IXODES, coradas com fucsina e verde malaquita 62

\section{\# QUADROS}

Quadro 1 - Número de amostras de sangue colhidas por município estudado . 47

\section{\# TABELAS}

Tabela 1 - "Primers" utilizados para identificação gênica de riquétsias 38

Tabela 2 - Pulgas colhidas sobre gambás em municípios do Estado de São Paulo, 2003-2006 48

Tabela 3 - Pulgas colhidas sobre cães e gatos em municípios do Estado de São Paulo, 2003-2006 48

Tabela 4 - Carrapatos colhidos sobre gambás em municípios do Estado de São Paulo, 2003-2006 
Tabela 5 - Carrapatos colhidos sobre cães em municípios do Estado de São Paulo, 2003-2006 ....................................................................... 50

Tabela 6 - Carrapatos colhidos sobre gatos em municípios do Estado de São Paulo, 2003-2006 50

Tabela 7 - Pulgas positivas na PCR, para o gene gltA, colhidas sobre gambás capturados no Estado de São Paulo .......................................... 51

Tabela 8 - Pulgas positivas na PCR, para o gene gltA, colhidas sobre cães e gatos no Estado de São Paulo

Tabela 9 - Carrapatos positivos na PCR, para o gene gltA, colhidos sobre gambás capturados no Estado de São Paulo

52

Tabela 10 - Amostras de DNA de riquétsias seqüenciadas em carrapatos positivos na $\mathrm{PCR}$, para o gene gltA, colhidos sobre gambás capturados no Estado de São Paulo 53

Tabela 11 - Grau de identidade calculado para cada par de seqüências de nucleotídeos, entre as amostras de pulgas obtidas, através do sequenciamento de DNA (gene gltA, $350 \mathrm{pb}$ ) e seqüências de Rickettsia spp do GenBank 54

Tabela 12 - Grau de identidade calculado para cada par de seqüências de nucleotídeos, entre as amostras de carrapatos obtidas, através do sequenciamento de DNA (gene gltA, $350 \mathrm{pb}$ ) e seqüências de Rickettsia spp do GenBank 54

Tabela 13 - Grau de identidade calculado para cada par de seqüências de nucleotídeos, entre uma amostra pool de carrapatos Amblyomma spp colhida sobre gambá, através do sequenciamento de DNA (gene gltA, 350 pb) e seqüências de Rickettsia spp do GenBank 55

Tabela 14 - Presença de anticorpos anti-Rickettsia spp em gambás do Estado de São Paulo, através da reação de imunofluorescência indireta 56

Tabela 15 - Presença de anticorpos anti-Rickettsia spp em cães do Estado de São Paulo, através da reação de imunofluorescência indireta 57

Tabela 16 - Presença de anticorpos anti-Rickettsia spp em gatos do Estado de São Paulo, através da reação de imunofluorescência indireta 57

Tabela 17 - Presença de anticorpos anti-Rickettsia spp em eqüinos do Estado de São Paulo, através da reação de imunofluorescência indireta 58

Tabela 18 - Presença de anticorpos anti-Rickettsia spp em humanos do Estado de São Paulo, através da reação de imunofluorescência indireta .. 58 
Tabela 19 - Títulos de anticorpos anti-Rickettsia spp através da reação de imunofluorescência indireta (RIFI), em gambás, cães, eqüinos e humanos, de cinco áreas do estado de São Paulo para quatro espécies de Rickettsia 59

Tabela 20 - Grau de identidade calculado para cada par de seqüências de nucleotídeos, entre Rickettsia felis cepa PEDREIRA isolada de pulgas Ctenocephalides felis felis de cães, através do sequenciamento de DNA (gene gltA, 1.070 pb) e seqüências de Rickettsia spp do GenBank. 2006 63

Tabela 21 - Grau de identidade calculado para cada par de seqüências de nucleotídeos, entre Rickettsia felis cepa PEDREIRA isolada de pulgas Ctenocephalides felis felis de cães, através do sequenciamento de DNA (gene $17 \mathrm{kDa}, 376 \mathrm{pb}$ ) e seqüências de Rickettsia spp do GenBank. 2006 64

Tabela 22 - Grau de identidade calculado para cada par de seqüências de nucleotídeos, entre Rickettsia felis cepa PEDREIRA isolada de pulgas Ctenocephalides felis felis de cães, através do sequenciamento de DNA (gene $O m p B, 703 \mathrm{pb}$ ) e seqüências de Rickettsia spp do GenBank. 2006 65

Tabela 23 - Grau de identidade calculado para cada par de seqüências de nucleotídeos, entre Rickettsia bellii cepa IXODES isolada de carrapato Ixodes loricatus de gambá, através do sequenciamento de DNA (gene gltA, 1.109 pb) e seqüências de Rickettsia spp do GenBank. 2006 66

Tabela 24 - Grau de identidade calculado para cada par de seqüências de nucleotídeos, entre Rickettsia bellii cepa IXODES isolada de carrapato Ixodes loricatus de gambá, através do sequenciamento de DNA (gene 17kDa, 376 pb) e seqüências de Rickettsia spp do GenBank. 2006 67 


\begin{tabular}{|c|c|c|}
\hline GT & $=$ & Grupo do Tifo \\
\hline GFM & $=$ & Grupo das Febres Maculosa \\
\hline GA & $=$ & Grupo Ancestral \\
\hline FMB & $=$ & Febre Maculosa Brasileira \\
\hline EUA & $=$ & Estados Unidos da América \\
\hline ESALQ & $=$ & Escola Superior de Agricultura Luiz de Queiroz \\
\hline FMVZ & $=$ & Faculdade de Medicina Veterinária e Zootecnia \\
\hline USP & $=$ & Universidade de São Paulo \\
\hline CVE & $=$ & Centro de Vigilância Epidemiológica \\
\hline SUCEN & $=$ & Superintendência de Controle de Endemias \\
\hline DEPAVE & $=$ & Departamento de Parques e Áreas Verdes \\
\hline B.O.D. & $=$ & Biological Oxygen Demand \\
\hline PCR & $=$ & Polymerase Chain Reaction - Reação em Cadeia pela Polimerase \\
\hline DNA & $=$ & Deoxyribonucleic Acid - Ácido Desoxirribonucléico \\
\hline rRNA & $=$ & Ribonucleic Acid - Ácido Ribonucléico Ribossômico \\
\hline Taq & $=$ & Thermus aquaticus \\
\hline OmpA & $=$ & Outher membrane protein $A$ - proteína externa de membrana A \\
\hline OmpB & $=$ & Outher membrane protein $B$ - proteína externa de membrana B \\
\hline gltA & $=$ & gene citrato sintase \\
\hline RIFI & $=$ & Reação de Imunofluorescência Indireta \\
\hline
\end{tabular}




$\begin{array}{ll}\text { SFB } & =\text { Soro fetal bovino } \\ \text { SBB } & =\text { Soro de bezerro bovino } \\ \text { EDTA } & =\text { ácido etileno-diamino-tetracético } \\ \text { TBE } & =\text { tris-borato-EDTA } \\ \text { TE } & =\text { tampão TRIS HCl-EDTA } \\ \text { TRIS } \quad=\text { tris(hidroximetil)amino metano } & \text { Phosphate Buffered Saline solution }- \text { Solução fosfato tamponada } \\ \text { PBS } \quad=\quad \text { Gobal Position System } \\ \text { GPS } \quad=\quad \text { pares de bases } \\ \text { pb } \quad=\quad \text { colaboradores } \\ \text { et al. }\end{array}$

OBS: Algumas abreviaturas seguem as iniciais de sua grafia no idioma inglês, visto terem seu uso consagrado na literatura técnica. 


$$
\begin{aligned}
& \mathrm{cm}=\text { centímetros } \\
& \mathrm{mm}=\text { milímetros } \\
& { }^{\circ} \mathrm{C} \quad=\text { graus Celcius } \\
& \mathrm{M}=\text { molar } \\
& \mathrm{mM}=\text { mili molar } \\
& \mathrm{U} \quad=\text { unidades } \\
& \text { g = grama } \\
& \mu \mathrm{g} \quad=\text { micrograma } \\
& \mathrm{mL}=\text { mililitro } \\
& \mu \mathrm{L} \quad=\text { microlitro } \\
& \mu \mathrm{m} \quad=\text { micrometro } \\
& \mathrm{xg}=\text { múlttiplos da gravidade terrestre }\left(9,81 \mathrm{~m} / \mathrm{s}^{2}\right) \\
& \mathrm{kDa}=\text { kilodalton } \\
& \mathrm{pH} \quad=\text { potencial hidrogeniônico } \\
& \min =\text { minutos } \\
& \text { seg = segundos } \\
& \%=\text { por cento } \\
& =\quad=\text { igual } \\
& \approx \quad=\text { semelhante } \\
& \cong \quad=\text { aproximadamente } \\
& >\quad=\text { maior } \\
& \geq \quad=\text { maior ou igual } \\
& \text { ( }) \quad=\text { marca registrada } \\
& \mathrm{x}=\text { vezes }
\end{aligned}
$$




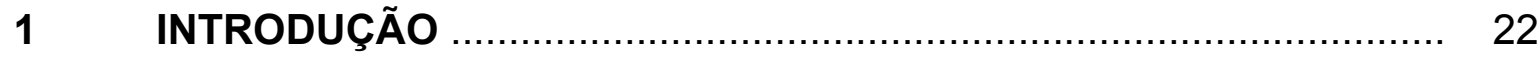

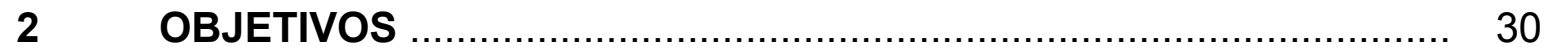

$3 \quad$ MATERIAIS E MÉTODOS …................................................... 31

3.1 LOCAL DE ESTUDO …............................................................ 31

3.1.1 Grupo 1 - Áreas com Casos Confirmados de Febre Maculosa ..... 32

3.1.2 Grupo 2 - Área sem Casos Confirmados de Febre Maculosa ........ 33

3.2 CAPTURA DE GAMBÁS .............................................................. 34

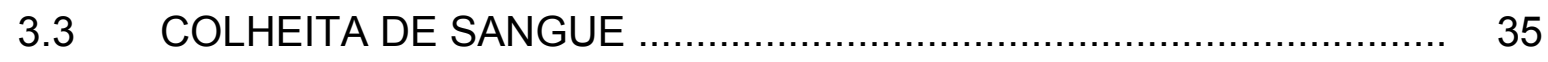

$3.4 \quad$ COLHEITA DE ECTOPARASITOS ................................................. 35

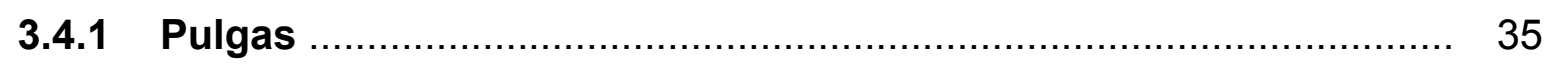

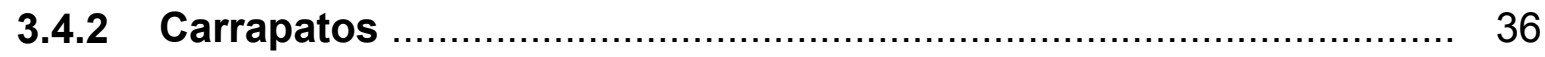

3.5 PESQUISA DE RIQUÉTSIAS EM POTENCIAIS VETORES ............... 37

3.5.1 Extração de DNA …............................................................. 37

3.5.2 Reação em Cadeia pela Polimerase (PCR) ….................................. 37

3.5.3 Purificação e Sequenciamento de DNA …..................................... 39

3.6 PESQUISA DE RIQUÉTSIAS EM POTENCIAIS HOSPEDEIROS

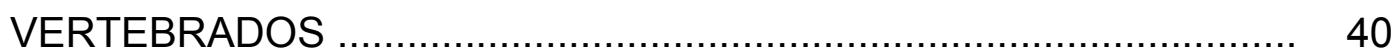

3.6.1 Produção de Lâminas de Antígeno ……................................... 40

3.6.2 Reação de Imunofluorescência Indireta ........................................ 41

3.6.2 Extração de DNA …............................................................... 42

3.6.3 PCR, Purificação e Sequenciamento de DNA …............................ 42 
3.7 CULTIVO CELULAR

3.7.1 Células VERO

3.7.2 Células $\mathrm{C} 6 / 36$

3.7.3 Isolamento de Rickettsia felis

3.8 ANÁLISE ESTATÍSTICA

4.1 CAPTURA E IDENTIFICAÇÃO DE GAMBÁS 46

4.2 COLHEITA DE SANGUE

4.3 COLHEITA DE ECTOPARASITOS

4.3.1 Pulgas

4.3.2 Carrapatos 48

4.4

PESQUISA DE RIQUÉTSIAS EM POTENCIAIS VETORES

4.4.1 Reação em Cadeia pela Polimerase (PCR)

4.4.2 Sequenciamento de DNA

4.5 PESQUISA DE RIQUÉTSIAS EM POTENCIAIS HOSPEDEIROS 55

4.5.1 Imunofluorescência indireta 55

4.5.1.1 Gambás 55

4.5.1.2 Cães 56

4.5.1.3 Gatos

4.5.1.4 Eqüinos

4.5.1.4 Humanos 
SUMÁRIO (CONTINUAÇÃO)

4.5.2 Reação em Cadeia pela Polimerase (PCR)

4.6 CULTIVO CELULAR

4.6.1 Isolamento de Rickettsia felis

4.6.2 Isolamento de Rickettsia bellii

5 DISCUSSÃO

6 CONCLUSÕES

REFERÊNCIAS

APÊNDICES
60

60

60

61

68

77

79

90 


\section{INTRODUÇÃO}

As doenças causadas por riquétsias estão amplamente distribuídas pelo mundo em focos endêmicos e geralmente aparecem em intervalos esporádicos, reemergindo de forma epidêmica na população humana (AZAD; BEARD, 1998). As riquetsioses estão associadas a diversos artrópodes, incluindo piolhos, pulgas, carrapatos e outros ácaros (RAOULT; ROUX, 1997). A interação dessas bactérias, tanto com hospedeiros vertebrados (reservatórios ou suscetíveis) como com seus vetores, constitui um excelente modelo de estudo do complexo hospedeiro-parasita. A interação do agente com artrópodes que se alimentam de sangue representa um importante passo na evolução biológica dos organismos. As relações íntimas das riquétsias com os vetores são caracterizadas pela eficiência de sua multiplicação e estabelecimento no artrópode, transmissão transestadial e transovariana e, ainda, pela sua distribuição geográfica e ecológica. As riquétsias diferem consideravelmente em termos do vetor, distribuição geográfica e virulência (AZAD; BEARD, 1998).

O gênero Rickettsia é composto pelo "Grupo do Tifo" (GT) e pelo "Grupo da Febre Maculosa" (GFM). Um terceiro grupo, denominado "Grupo Ancestral" (GA), foi proposto por Sekeyova, Roux e Raoult (2001), e inclui Rickettsia canadensis e Rickettsia bellii, bactérias de patogenicidade ainda desconhecida. O GT inclui Rickettsia prowazekii, causadora do tifo epidêmico, e Rickettsia typhi, agente do tifo endêmico ou tifo murino (EREMEEVA; DASCH, 2000). O GFM é constituído por mais de 30 espécies, dentre as quais pelo menos 15 causam diferentes doenças ao homem (Rickettsia aeschlimannii, Rickettsia africae, Rickettsia akari, Rickettsia 
australis, Rickettsia conorii, Rickettsia felis, Rickettsia helvetica, Rickettsia honei, Rickettsia japonica, Rickettsia marmionii, Rickettsia mongolotimonae, Rickettsia parkeri, Rickettsia rickettsii, Rickettsia sibirica, Rickettsia slovaca). Com exceção de $R$. akari e R. felis transmitidas por pequenos ácaros e pulgas, respectivamente, todas as outras representantes desse grupo são veiculadas por carrapatos (BROUQUI et al., 2004; RAOULT; ROUX, 1997; RAOULT et al., 2002; SEKEYOVA; ROUX; RAOULT, 2001).

No Brasil, a doença causada por riquétsias do GFM é denominada Febre Maculosa Brasileira (FMB), tendo sido notificada em todos os estados da região Sudeste do país (DIAS; MARTINS, 1939; SEXTON et al., 1993). Os casos comprovados da doença com transmissão por carrapatos do gênero Amblyomma são conhecidos desde a década de 30 . A doença é causada pela bactéria Rickettsia rickettsii; contudo, com o avanço das pesquisas, principalmente no âmbito da biologia molecular, outras riquétsias foram caracterizadas nos últimos anos na região Sudeste, como Rickettsia bellii e Rickettsia sp ( $\approx$ Rickettsia parkeri) em carrapatos Amblyomma dubitatum (antigo Amblyomma cooperi) (LABRUNA et al., 2004a); $R$. bellii em Amblyomma aureolatum (PINTER, 2003); R. parkeri em Amblyomma triste (SILVEIRA et al., 2005); e R. felis, em pulgas Ctenocephalides felis felis (HORTA et al., 2005d; OLIVEIRA et al., 2002,) e em carrapatos Amblyomma spp (CARDOSO et al., 2006; HORTA, 2002; PINTER, 2003; VIANNA, 2002). Na região Norte do país, $R$. bellii e R. amblyommii foram caracterizadas em carrapatos do gênero Amblyomma (LABRUNA et al., 2004b) e R. rhipicephali em carrapatos Haemaphysalis juxtakochi (LABRUNA et al., 2005a). Em humanos, até o presente momento, somente a $R$. rickettsii foi isolada e caracterizada, oriunda de pacientes de diferentes localidades do Estado de São Paulo (GEHRKE et al., 2005; NASCIMENTO et al., 2005). 
Das 2.000 espécies e sub-espécies de pulgas existentes no mundo, apenas algumas atuam como vetores de doenças humanas, tais como a peste bubônica ou peste negra (Yersinia pestis), tifo murino (R. typhi), riquetsiose felis ( $R$. felis) e doença da arranhadura do gato (Bartonella henselae). Vários agentes transmitidos pelas pulgas são mantidos em um ciclo zoonótico envolvendo mamíferos como hospedeiros naturais, tais como roedores, cães e gatos selvagens, gambás, guaxinins e esquilos. Esses vetores são trazidos para o interior das casas por animais domésticos. Contudo, essas doenças tornam-se epidêmicas, nas populações humanas, apenas quando há uma diminuição populacional desses hospedeiros naturais, fazendo com que as pulgas passem a procurar outras fontes de alimento, tornando o homem um hospedeiro acidental (AZAD et al., 1997).

Rickettsia felis já foi descrita em todos os continentes. Inicialmente denominada "agente ELB" (Els Labs, Soquel, CA), foi observada pela primeira vez em tecidos da pulga do gato (Ctenocephalides felis Bouché) através de microscopia eletrônica nos EUA (ADAMS; SCHMIDTMAN; AZAD, 1990). O nome Rickettsia felis (de Felis domesticus, o gato doméstico) foi proposto, em 1996, quando a sua diferença com outras riquétsias do mesmo gênero foi esclarecida (HIGGINS et al., 1996). O agente foi associado a casos clínicos de febre maculosa em pacientes no Texas (EUA), inicialmente suspeitos de terem contraído tifo murino (SCHRIEFER et al., 1994a). Embora a doença em humanos causada por R. felis seja clinicamente semelhante à causada por $R$. rickettsii, suspeita-se que o primeiro agente deva ser menos virulento, dada a ausência de relatos de casos letais. Classicamente, $R$. rickettsii é reconhecida, desde o início do século passado, como responsável pela alta letalidade dos casos clínicos em humanos não tratados (DIAS; MARTINS, 1939; ZAVALA-VELÁZQUEZ et al., 2000). Além dos EUA, casos humanos de febre 
maculosa, causados por $R$. felis, foram notificados no México (ZAVALAVELÁZQUEZ et al., 2000), Brasil, França (RAOULT et al., 2001), Alemanha (RICHTER et al., 2002) e Tailândia (PAROLA et al., 2003).

Paralelamente, o agente foi detectado em pulgas nos EUA (ADAMS; SCHMIDTMAN; AZAD, 1990; HIGGINS et al., 1994), México (ZAVALA-VELAZQUEZ et al., 2002), Brasil (HORTA et al., 2005d; OLIVEIRA et al., 2002), Peru (BLAIR et al., 2004), Uruguai (VENZAL et al., 2005), Espanha (MÁRQUEZ et al., 2002), Reino Unido (KENNY et al., 2003; SHAW et al., 2004), Tailândia (PAROLA et al., 2003), Nova Zelândia (KELLY et al., 2004), Gabão (ROLAIN et al., 2005) e Tunísia (ZNAZEN et al., 2006).

No Brasil, pouco se conhece sobre a epidemiologia da riquetsiose causada pela $R$. felis, sua relação com casos de febre maculosa originadas por outras riquétsias ou sobre sua interação com outras bactérias e vetores. A doença foi diagnosticada no país apenas em 2001, no Estado de Minas Gerais, através da detecção de $R$. felis a partir do sangue de pacientes que apresentavam sinais clínicos compatíveis com febre maculosa (RAOULT et al., 2001). Posteriormente, o agente foi detectado e caracterizado através de técnicas moleculares em pulgas colhidas de cães provenientes de uma área com casos suspeitos de febre maculosa (OLIVEIRA et al., 2002). A presença desta bactéria foi detectada em carrapatos Amblyomma spp, colhidos em áreas endêmicas para $\mathrm{FMB}$, tanto em Minas Gerais como em São Paulo (CARDOSO et al., 2006; HORTA, 2002; PINTER, 2003; VIANNA, 2002). Entretanto, não se sabe exatamente se existe uma efetiva participação dos carrapatos no ciclo da $R$. felis nas regiões estudadas. A interação entre essa bactéria e o carrapato, além da comprovação da capacidade e competência vetorial, precisam ser melhor estudadas. 
O agente $R$. felis é uma bactéria intracelular obrigatória, gram-negativa da ordem Rickettsiales. Cresce em células XTC-2 (derivada do anfíbio Xenopus laevis) e em células VERO (derivada de rim de macaco), embora nesse último tipo celular apresente uma taxa de infecção inferior a 50\% (RAOULT et al., 2001). Radulovic et al. (1995) consideraram R. felis como pertencente ao grupo do tifo, devido a características comuns a esse grupo, como propriedades biológicas, padrões de cultivo celular e similaridade antigênica. No entanto, anos mais tarde, foi descoberto que houve contaminação laboratorial por $R$. typhi e que as características reportadas não eram, na verdade, causadas pela R.felis (RADULOVIC et al., 1996).

Posteriormente, ensaios moleculares visando uma adequada caracterização da bactéria foram realizados. A análise das seqüências de bases de um fragmento amplificado (434 pb) do gene que codifica a proteína 17 kDa (proteína de superfície comum a espécies do gênero Rickettsia) indicou tratar-se de uma bactéria distinta das demais riquétsias GT, inclusive de $R$. typhi, principal espécie encontrada em pulgas até então (AZAD et al., 1992). A análise do gene 16S rRNA, usada para estudos filogenéticos de bactérias, aproximou $R$. felis de duas bactérias do GFM, $R$. akari e R. australis, tendo as três bactérias diferentes espécies de vetores (STOTHARD; FUERST, 1995). Estudo semelhante, com análise do gene codificador da Citrato Sintase, obteve resultados que corroboram os trabalhos anteriores (HIGGINS et al., 1996). No entanto, estudos preliminares não foram capazes de detectar o antígeno de proteína externa de membrana $(\mathrm{OmpA})$, encontrado em todas as espécies de riquétsias pertencentes ao GFM (HIGGINS et al., 1996). Finalmente, em 2001, com base no sequenciamento e análise de DNA do gene OmpA, descrito pela primeira vez nessa bactéria, a inclusão da $R$. felis no GFM foi admitida (BOUYER et al., 2001). 
Ctenocephalides felis é a espécie de pulga de maior prevalência encontrada em gambás, cães e gatos do continente Americano. Na análise realizada através de PCR de exemplares colhidos de gambás no Texas (EUA), 3,8\% desses apresentaram-se positivos para $R$. felis e $0,8 \%$ para $R$. typhi, fato que sugere um importante papel do gambá na manutenção do ciclo epidemiológico dessas riquétsias. Na natureza, ainda não foram encontradas essas duas bactérias cohabitando a mesma pulga (SCHRIEFER et al., 1994a,b); entretanto, foi possível detectar a presença de ambos agentes em pulgas previamente infectadas com $R$. felis com subseqüente infecção experimental por $R$. typhi, indicando laboratorialmente a possibilidade de co-existência no mesmo vetor. Nessa condição, a taxa de infecção das pulgas por $R$. felis decaiu de $86 \%$ - 94\% para $13-26 \%$ (NODEN et al., 1998).

Nos EUA, em estudo de pulgas colhidas de gambás (Didelphis virginiana), cães e gatos procedentes de várias regiões geográficas, no período de 1986 a 1996, verificou-se a presença de $R$. felis em mais de $50 \%$ das amostras estudadas. No entanto, essa taxa chegou a 93\% em alguns dos locais examinados, demonstrando a vasta distribuição da bactéria em habitats sub-urbanos, onde gambás adentram em habitações humanas e compartilham pulgas com cães e gatos (HIGGINS et al., 1994). A infecção de $R$. felis é mantida por transmissão vertical (transovariana) por sucessivas gerações da pulga, sem a necessidade de um reservatório vertebrado, o que justifica a alta incidência dos agentes nesses vetores (WEDINCAMP; FOIL, 2002). Além disso, infecções por $R$. typhi e $R$. felis não são letais para seus vetores naturais, diferentemente do que acontece com outras riquétsias, como por exemplo R. prowazekii (AZAD et al., 1997) e R. rickettsii (NIEBYLSKI; PEACOCK; SCHWAN, 1999) para piolhos e carrapatos, respectivamente. 
No Brasil, os eqüinos assumem o papel de sentinela da febre maculosa (HORTA et al., 2004; LEMOS et al., 1996a; SANGIONI et al., 2005). Em áreas endêmicas para FMB nos Estados de Minas Gerias e São Paulo, estes animais se apresentam com altos títulos de anticorpos frente a $R$. rickettsii, possivelmente correlacionados ao alto parasitismo destes animais pelo carrapato vetor $A$. cajennense (HORTA et al., 2004; SANGIONI et al., 2005; VIANNA, 2002). Os cães, gatos e gambás apresentam papel importante como hospedeiros da pulga. Os gambás, em particular, são incriminados como potencial reservatório silvestre de riquétsias. Até hoje, no país, o único isolado de Rickettsia $\mathrm{sp}$ de animal silvestre ocorreu am gambá Didelphis marsupialis (MOREIRA et al., 1935). Em soros colhidos de gatos febris, notificados por veterinários no nordeste dos EUA, observou-se uma soropositividade frente à $R$. felis de $8 \%$, indicando uma possível ligação destes animais na transmissão do agente (HIGGINS et al., 1996). Ainda não foram realizados estudos sobre a participação de cães e gatos como fontes de infecção para R. felis.

A soropositividade de animais para tifo murino está relacionada com a doença detectada em humanos. A sorologia, realizada utilizando-se antígenos de R. typhi, realizada em gambás e gatos demonstrou uma positividade de $40 \%$ e $90 \%$, respectivamente. Em áreas controles, onde a doença não foi detectada, nenhum animal se apresentou positivo (SORVILLO et al., 1993). Não existe, até o momento, trabalho relacionando a sorologia frente a $R$. felis em áreas endêmicas ou não para febre maculosa.

Todos os testes sorológicos, incluindo a maioria daqueles realizados pelos laboratórios de referência para diagnóstico da doença no Brasil, utilizam antígenos cedidos por pesquisadores americanos e europeus (R. rickettsii e R.typhi). Para o 
diagnostico da febre maculosa, estes métodos sorológicos são válidos, uma vez que todas as bactérias do GFM apresentam reações cruzadas entre si. No entanto, os títulos se apresentam mais elevados quando testados contra seu antígeno específico (reação homóloga) (PHILIP et al., 1978).

A transmissão de $R$. felis aos humanos precisa ser melhor estudada. Não se sabe se a infecção se dá pelo contato com secreções salivares ou através da picada do artrópode, tal como ocorre com várias espécies de riquétsias veiculadas por carrapatos, ou através de restos celulares e/ou fezes de vetores contaminados, verificada na transmissão de $R$. typhi por pulgas ou de $R$. prowazekii por piolhos (AZAD; BEARD, 1998). Macerados de fezes de pulgas infectadas se apresentaram positivas para $R$. felis quando testadas pela PCR. Contudo, isso pode indicar que o DNA encontrado estivesse apenas transitando pelo intestino da pulga, não esclarecendo sobre o estabelecimento de uma infecção na mesma. A transmissão horizontal de $R$. felis, via alimentação de larvas de pulgas com fezes de vetor infectado, foi estudada, porém, não apresentou resultados positivos. (WEDINCAMP et al., 2002).

Em resumo, embora a FMB tenha como principal agente a $R$. rickettsii há várias décadas, a riquetsiose causada por $R$. felis foi identificada somente há alguns anos. Os achados de R. felis em pulgas e carrapatos, provenientes de áreas endêmicas no Estado de São Paulo, são intrigantes e indicam a possível participação de mais uma espécie de riquétsia na etiologia da doença. Por esta razão, tornam-se necessárias investigações sobre a história natural destes agentes que poderão fornecer subsídios para o entendimento da epidemiologia da febre maculosa e auxiliar na escolha das estratégias visando prevenção e controle da doença. 


\section{OBJETIVOS}

Este estudo visou buscar o entendimento do ciclo epidemiológico de Rickettsia felis em áreas endêmicas e não-endêmicas para febre maculosa no Estado de São Paulo, através de:

1. Colheita e identificação de pulgas e carrapatos, em fase de parasitismo, de cães, gatos e gambás.

2. Determinação da prevalência de infecção por riquétsias em pulgas, carrapatos e no sangue de seus hospedeiros (cães, gatos e gambás), através da técnica de reação em cadeia pela polimerase (PCR).

3. Caracterização molecular das riquétsias encontradas nos ectoparasitos e no sangue de seus hospedeiros, através do sequenciamento e análise do DNA amplificado.

4. Determinação da prevalência de anticorpos anti-R. rickettsii, anti-R. parkeri, anti$R$. felis e anti- $R$. bellii em soros de gambás, cães, gatos, eqüinos e humanos; através da reação de imunofluorescência indireta.

5. Isolamento de R. felis, através do cultivo celular, a partir de pulgas colhidas de cães residentes nas áreas investigadas. 


\subsection{LOCAL DE ESTUDO}

Este estudo foi realizado em propriedades localizadas em municípios situados em áreas endêmicas e não-endêmicas para febre maculosa brasileira (FMB), no Estado de São Paulo. Os municípios foram escolhidos e agrupados a partir da análise dos dados referentes aos casos humanos de febre maculosa nos últimos 21 anos (CVE, 2006). O número de municípios foi escolhido conforme a capacidade operacional do projeto (Figura 1).

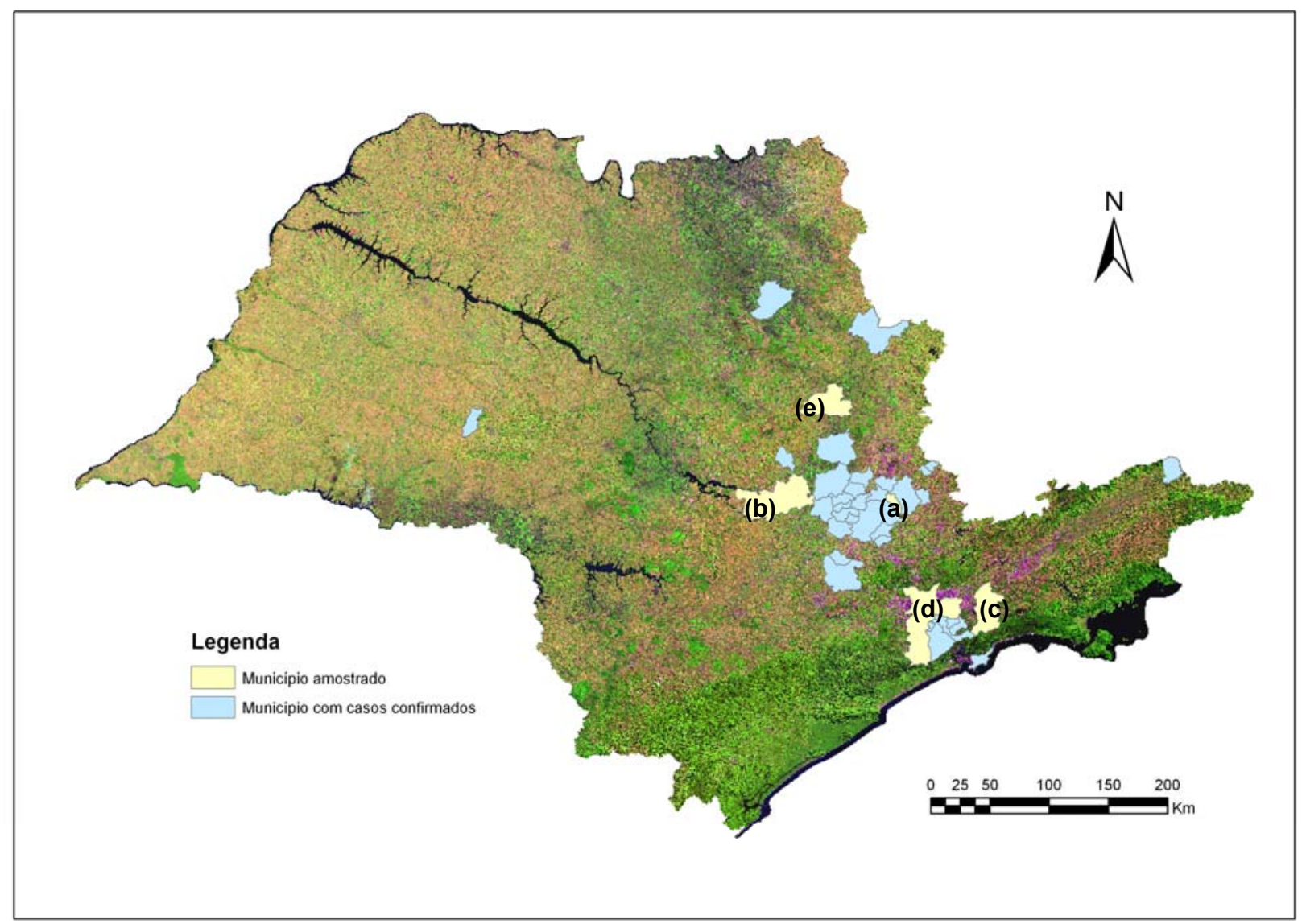

Figura 1 - Distribuição dos casos e febre maculosa no Estado de São Paulo: 19852005. CVE, 2006. Em destaque: áreas de estudos: (a) Pedreira, (b) Piracicaba, (c) Mogi das Cruzes, (d) São Paulo, (e) Pirassununga 


\subsubsection{Grupo 1 - Áreas com Casos Confirmados de Febre Maculosa}

O município de Pedreira é considerado área endêmica para a doença desde 1985, quando surgiram as primeiras suspeitas diagnósticas na região. Estudos realizados no município comprovam a ocorrência de, pelo menos, quatro espécies de riquétsias na região: $R$. bellii, $R$. rickettsii, $R$. felis e Rickettsia sp ( $\approx$ Rickettsia parkeri) (HORTA et al., 2004; HORTA et al., 2005d, LABRUNA et al., 2004a; NASCIMENTO et al., 2005). Foram escolhidos quatro sítios de coleta, todos representando locais prováveis de infecção para humano: 1) Fazenda Santa Tereza, 2) Fazendas Jaguari/ Monte Nilo, 3) Fazendas Quitandinha/Ingatuba e 4) Zoobosque (região central).

No município de Mogi das Cruzes, endêmico para FMB, foram relatados quatro casos humanos fatais no ano de 1998 (FONTES et al., 2000). Até o presente momento, $R$. rickettsii, $R$. bellii e $R$. felis foram detectadas na região (HORTA et al., 2005d; PINTER; LABRUNA, 2005). O sítio de coleta está localizado em locais prováveis de infecção no distrito de Taiaçupeba, zona sul do município.

Nos últimos quatro anos, no município de Piracicaba, ocorreram 14 casos confirmados da doença. Algumas áreas prováveis de infecção estão situadas dentro dos limites do Campus da Escola Superior Luis de Queiroz - ESALQ/USP, localizada na área urbana da cidade (CVE, 2006).

No município de São Paulo, no primeiro terço do século passado, houve relatos da doença, que desapareceram depois do aumento da urbanização da cidade. Nos últimos quatro anos, foram notificados cinco casos confirmados pelo Centro de Vigilância Epidemiológica (CVE, 2006). São quatro os sítios de coleta do 
município: 1) Campus da USP (zona oeste), 2) Parque Ibirapuera (zona Sul), 3) SESC Interlagos (Zona sul) e 4) outras áreas do município.

\subsubsection{Grupo 2 - Área sem Casos Confirmados de Febre Maculosa}

No município de Pirassununga, não há relatos da doença, constituindo assim área controle do presente estudo. O sítio de coleta é o campus da USP de Pirassununga, que apresenta condições geográficas semelhantes às áreas pertencentes ao Grupo 1 (SANGIONI et al., 2005).
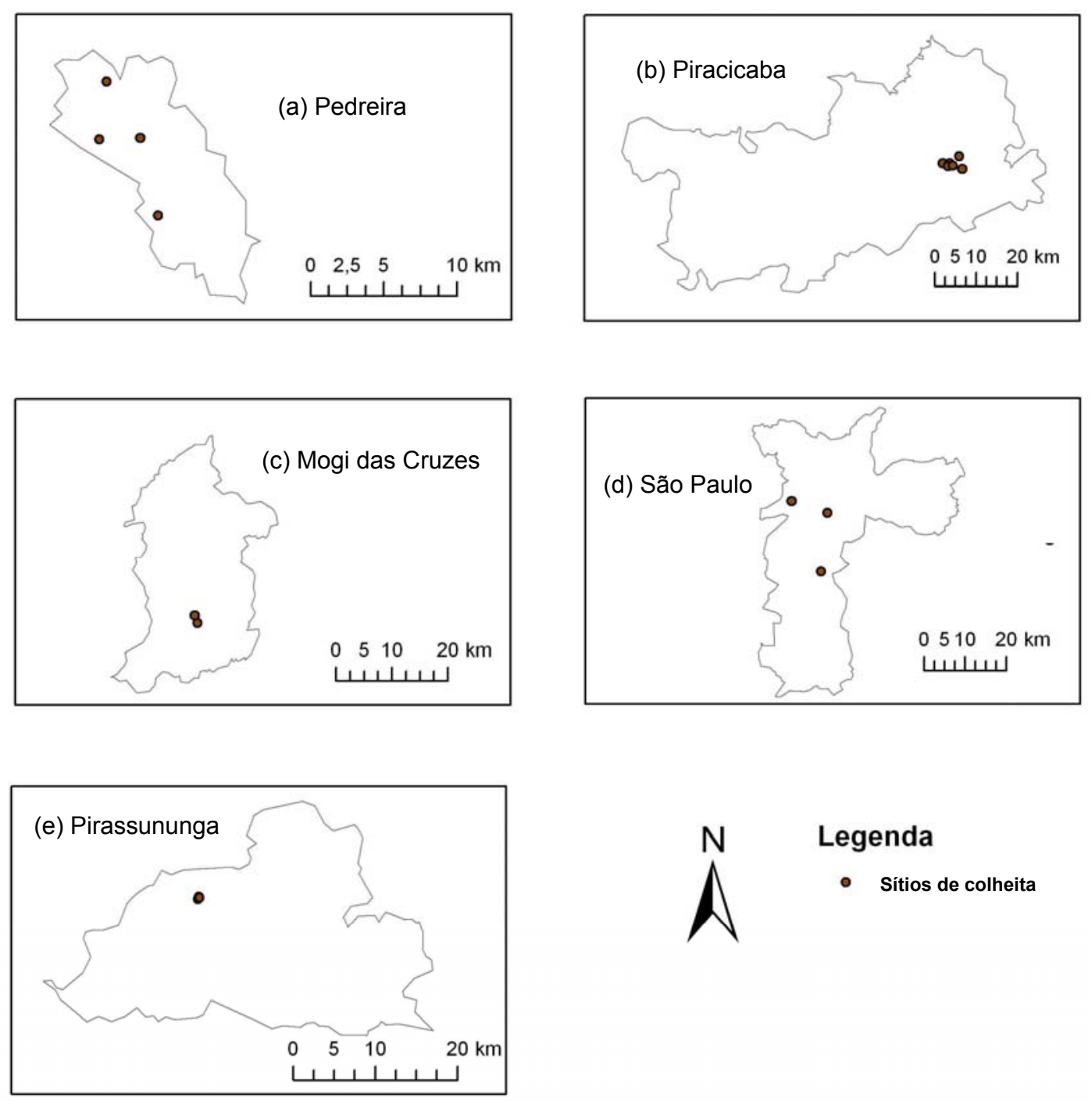

Figura 2 - Sítios de Colheita: (a) Pedreira, (b) Piracicaba, (c) Mogi das Cruzes, (d) São Paulo, (e) Pirassununga 


\subsection{CAPTURA DE GAMBÁS}

Nas localidades estudadas, foram realizadas capturas de gambás de vida livre. Devido a variações climáticas, época do ano, densidade populacional, dentre outros fatores, foi necessária a realização de várias viagens a campo em um mesmo local para atingir sucesso nas capturas. Com isso, o esforço de captura dos gambás variou entre 15 a 25 dias de trabalho, em cada localidade, envolvendo os seguintes números de viagens: 3 para Mogi das Cruzes, 4 para Pedreira, 4 para Pirassununga e 5 para Piracicaba. Objetivou-se atingir a captura mínima 12 gambás/localidade, por constituir uma expectativa numérica baseada em estudos epidemiológicos envolvendo capturas de gambás (CÁCERES; MONTEIRO-FILHO, 2001). A exceção foi o município de São Paulo, onde, além das capturas, o Departamento de Parques e Áreas Verdes (DEPAVE/Prefeitura Municipal), forneceu material biológico de 14 gambás.

Foram utilizadas 30 armadilhas de arame galvanizado, do tipo "live-trap", nas

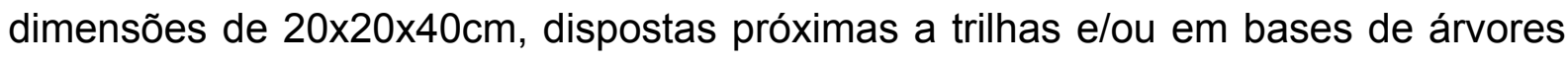
das matas. As armadilhas eram montadas no período vespertino e vistoriadas na manhã seguinte. As iscas utilizadas para atrair os animais foram alimentos embutidos (bacon, mortadela, salsicha) e frutas (banana, laranja, goiaba). As armadilhas eram lavadas após a captura dos animais, de modo a eliminar os odores naturais deixado por alguns mamíferos (LINARDI; GUIMARÃES, 2000).

Após a captura dos gambás, procedeu-se a sedação dos mesmos com quetamina $($ Vetaset $($, Quetamina $50 \AA$, Vetanarcol () ). Em seguida, realizou-se a colheita de sangue por via intracardíaca, intracaudal ou intramamária (fêmeas), conforme a viabilidade destes. Uma vez colhido o sangue, cada animal foi 
minuciosamente examinado para a colheita dos ectoparasitos. Os gambás foram marcados através de perfuração auricular $(2 \mathrm{~mm})$, para que pudessem ser identificados no caso de serem novamente capturados. Após os procedimentos, os animais foram liberados no mesmo local onde foram encontrados.

\subsection{COLHEITA DE SANGUE}

Em cada uma das áreas, além dos gambás, foram colhidas amostras de sangue de cães, gatos e eqüinos. Amostras de sangue de humanos que residiam nas propriedades em estudo e/ou que relataram histórico de infestação por carrapatos ou pulgas também foram colhidas com auxílio de enfermeiras devidamente credenciadas.

As colheitas foram realizadas por punção venosa, com auxílio de uma agulha e tubos de vidro estéreis. As amostras obtidas foram centrifugadas para obtenção de soro e separação do coágulo e, posteriormente, foram refrigeradas a $-20^{\circ} \mathrm{C}$.

\subsection{COLHEITA DE ECTOPARASITOS}

Pulgas e carrapatos foram colhidos a partir de cães, gatos e gambás capturados em cada um dos locais de estudo.

\subsubsection{Pulgas}

As pulgas colhidas de cães, gatos e gambás foram acondicionados em tubos plásticos, vedados e armazenados em embalagens térmicas (temperatura $\cong 24^{\circ} \mathrm{C}$ ). 
Em cada tubo plástico foi colocada uma quantidade de pêlos do hospedeiro para devido acondicionamento das mesmas, diminuindo assim a mortalidade durante transporte. No laboratório, as pulgas foram lavadas em álcool-iodado e identificadas de acordo com Linardi e Guimarães (2000).

\subsubsection{Carrapatos}

Os carrapatos colhidos a partir de cães, gatos e gambás foram colocados em frascos plásticos secos, vedados com tampas com pequenos furos e acondicionados em embalagens térmicas. Dentro dessas embalagens, colocou-se um pouco de capim para manutenção da umidade. No laboratório, os exemplares foram mantidos por pelo menos 72 horas em incubadora a $25^{\circ} \mathrm{C}$ e, a seguir, identificados (ARAGÃO; FONSECA, 1961).

Os estádios imaturos (larvas e ninfas) ingurgitados foram colocados na estufa B.O.D. $\left(25^{\circ} \mathrm{C}\right)$ para realização da ecdise. Alguns exemplares necessitaram de repasto em animais de laboratório, como coelhos (Oryctolagus cuniculus), ratos (Rattus norvergicus) e/ou cobaias (Cavia porcellus), para o desenvolvimento até a fase adulta, tornando possível sua classificação específica. Contudo, assim como ocorre na natureza, uma porcentagem dos carrapatos imaturos morreu antes de se tornarem adultos. Nesse caso, foram identificados de forma genérica. 


\subsection{PESQUISA DE RIQUÉTSIAS EM POTENCIAIS VETORES}

A reação em cadeia pela polimerase (PCR) a partir de DNA genômico extraído, objetivou o diagnóstico direto de riquétsias em carrapatos e pulgas colhidos sobre os animais.

\subsubsection{Extração de DNA}

A extração de DNA das riquétsias das pulgas e carrapatos foi realizada conforme o protocolo padronizado por Horta (2002), que consiste na maceração dos artrópodes em tubos, com auxílio de micropistilos. As pulgas e os adultos de carrapatos foram processados individualmente; e os estádios imaturos dos carrapatos (larvas e ninfas) foram processados individualmente ou em "pools" conforme a sua disponibilidade. No caso das pulgas e carrapatos imaturos utilizouse o indivíduo inteiro em carrapatos adultos somente as patas seccionadas. Cada amostra foi acrescida de $50 \mu \mathrm{l}$ de TE (10 mM Tris $\mathrm{HCl}$; $1 \mathrm{mM}$ EDTA, $\mathrm{pH} 8,0$ ), submetido à fervura $\left(100^{\circ} \mathrm{C}, 20 \mathrm{~min}\right) \mathrm{e}$, posteriormente, conservado a $-20^{\circ} \mathrm{C}$.

\subsubsection{Reação em Cadeia pela Polimerase (PCR)}

O preparo das soluções utilizadas nas reações, assim como o número de ciclos, tempos e temperaturas, foram adotados conforme cada tipo de fragmento do gene a ser pesquisado (EREMEEVA; YU; RAOULT, 1994; SCHRIEFER et al., 1994a; WEBB et al., 1990). Como controle positivo, foi utilizado DNA extraído de 
riquétsias de carrapatos experimentalmente infectados com $R$. parkeri, conservados a $-70^{\circ} \mathrm{C}$ (SANGIONI et al., 2005).

Para diagnóstico de detecção de Rickettsia spp, foram utilizados pares de oligunocleotídeos iniciadores ("primers") que amplificam fragmentos do gene glt $A$ (CS2-62/CS2-462 e CS3-922/CS3-1068) e do gene 17kDa (17K1/17K2 e 17K3/17K4). Para a realização do sequenciamento de DNA, o par de "primers" CS4239/CS4-1069 também foi utilizado (AZAD et al., 1990; LABRUNA et al., 2004a).

Para o diagnóstico diferencial de Rickettsia spp, pertencentes ao GFM, foram utilizados pares de "primers" que amplificam fragmentos dos genes que codificam proteínas externas de membrana das riquétsias, OmpA (A1-190.70/A3-190.701) (EREMEEVA; YU; RAOULT, 1994; RAOULT et al., 2001) e OmpB (B3-190.59/B4190.807) (RAOULT et al., 2001; ROUX; RAOULT, 2000).

As seqüências de nucleotídeos dos "primers", assim como a espécie de origem e o tamanho do produto amplificado estão relacionados na tabela 1.

Tabela 1 - "Primers" utilizados para identificação gênica de riquétsias

\begin{tabular}{|c|c|c|c|c|}
\hline $\begin{array}{l}\text { Pares de } \\
\text { "Primer" }\end{array}$ & $\begin{array}{l}\text { Espécie } \\
\text { de origem }\end{array}$ & Gene & $\begin{array}{l}\text { Seqüência de nucleotídeo } \\
\left(5^{\prime}-3^{\prime}\right)\end{array}$ & $\begin{array}{l}\text { Tamanho do } \\
\text { produto amplificado }\end{array}$ \\
\hline $\begin{array}{l}\text { CS2-62 } \\
\text { CS2-462 }\end{array}$ & R. rickettsii & gltA & $\begin{array}{c}\text { GCAAGTATCGGTGAGGATGTAAT } \\
\text { GCTTCCTTAAAATTCAATAAATCAGGAT }\end{array}$ & $401 \mathrm{pb}^{*}$ \\
\hline $\begin{array}{l}\text { CS3-922 } \\
\text { CS3-1068 }\end{array}$ & R. rickettsii & gltA & $\begin{array}{l}\text { GAGAGAAAATTATATATCCAAATGTTGAT } \\
\text { AGGGCTTTCGTGCATTTCTT }\end{array}$ & $147 \mathrm{pb}$ \\
\hline $\begin{array}{l}\text { CS4-239 } \\
\text { CS4-1069 }\end{array}$ & R. rickettsii & gltA & $\begin{array}{l}\text { GCTCTTCTCATCCTATGGCTATTAT } \\
\text { CAGGGTCTTCGTGCATTTCTT }\end{array}$ & $834 \mathrm{pb}$ \\
\hline $\begin{array}{l}17 \mathrm{~K} 1 \\
17 \mathrm{~K} 2\end{array}$ & R. rickettsii & $17 \mathrm{kDa}$ & $\begin{array}{l}\text { GCTCTTGCAACTTCTATGTT } \\
\text { CATTGTTCGTCAGGTTGGCG }\end{array}$ & $434 \mathrm{pb}$ \\
\hline $\begin{array}{l}17 \mathrm{~K} 3 \\
17 \mathrm{~K} 4\end{array}$ & R. rickettsii & $17 \mathrm{kDa}$ & $\begin{array}{l}\text { GCTTTACAAAATTCTAAAAACCATATA } \\
\text { TGTCTATCAATTCACAACTTGCC }\end{array}$ & $549 \mathrm{pb}$ \\
\hline $\begin{array}{l}\text { A1-190.70p } \\
\text { A3-190.701 }\end{array}$ & R. rickettsii & OmpA & $\begin{array}{l}\text { ATGGCGAATATTTCTCCAAAA } \\
\text { GTTCCGTTAATGGCAGCATCT }\end{array}$ & $631 \mathrm{pb}$ \\
\hline $\begin{array}{l}\text { B3-190.59 } \\
\text { B4-190.807 }\end{array}$ & R. rickettsii & OmpB & $\begin{array}{l}\text { CCGCAGGGTTGGTAACTGC } \\
\text { CCTTTTAGATTACCGCCTAA }\end{array}$ & $862 \mathrm{pb}$ \\
\hline
\end{tabular}


Para a visualização do fragmento de DNA amplificado, as amostras foram submetidas à eletroforese em gel de agarose a 1,5\%, em cuba horizontal contendo tampão de corrida TBE, sob $100 \vee(\cong$ 1hora), coradas por brometo de etídeo e observadas em luz de ultravioleta (SAMBROOK et al., 1989).

\subsubsection{Purificação e Sequenciamento de DNA}

Após a confirmação da positividade da amostra na PCR, o material amplificado foi purificado. Quando no gel foi observado apenas um fragmento positivo, sem ruídos da técnica, realizava-se a purificação a partir da amostra amplificada, com o protocolo etanol/propanol, que consiste na adição de $133 \mu \mathrm{l}$ de etanol $70 \%$ aos $40 \mu \mathrm{l}$ da amostra amplificada, seguido de centrifugação (12.000g, 25 min. $24^{\circ} \mathrm{C}$ ). $\mathrm{O}$ etanol foi cuidadosamente retirado do microtubo, acrescentando-se em seguida $133 \mu \mathrm{l}$ de isopronanol, procedendo-se uma nova centrifugação (12.000g, $25 \mathrm{~min} .24^{\circ} \mathrm{C}$ ). Após a retirada do isopropanol, o microtubo foi incubado à $90^{\circ} \mathrm{C}$ por 5 minutos. O pellet foi então o ressuspendido com adição de $50 \mu$ de TE (10 mM Tris $\mathrm{HCl} ; 1 \mathrm{mM}$ EDTA, pH 8,0).

A reação de sequenciamento foi feita usando o "Kit Big Dye 3.1", de acordo com as instruções do fabricante (4 $\mu$ l DNA purificado - concentração máxima de 100 nG, $1 \mu$ água mili $Q, 0,75 \mu l$ Big Dye, $1 \mu$ primers específicos "senso e anti-senso" $(5 p m o l e s / \mu l)$ e 3,25 $\mu \mathrm{l}$ "Save Money"). Foi utilizado o sequenciador de DNA modelo ABI Prism 3100 Genetic Analyser (Applied Biosystems/Perkin Elmer), segundo seu manual de instruções (“Automated DNA Sequencing”, 1998).

As seqüências dos fragmentos de DNA de Rickettsia spp, obtidas a partir de pulgas e carrapatos de gambás, cães e gatos, foram analisadas e comparadas às 
seqüências existentes no GenBank. As identidades das seqüências alinhadas pelo método Clustal/W foram calculadas com o programa BioEdit v. 7. 0. 5. (HALL, 1999).

\subsection{PESQUISA DE RIQUÉTSIAS EM POTENCIAIS HOSPEDEIROS VERTEBRADOS}

\subsubsection{Produção de Lâminas de Antígeno}

As lâminas contendo antígeno específico de R. rickettsii, R. parkeri, R. felis e R. bellii foram produzidas no laboratório de Doenças Parasitárias da Faculdade de Medicina Veterinária e Zootecnia da Universidade de São Paulo - FMVZ/USP.

Dentro do fluxo laminar, as lâminas foram previamente incubadas em acetona por 10 minutos. Após a secagem das mesmas, realizou-se limpeza com álcool etílico absoluto. Depois de nova secagem, colocou-se em cada poço da lâmina, com ajuda de uma haste flexível, solução de poli-L-lisina (Sigma-Aldrich Co). As lâminas foram deixaras à temperatura ambiente para uma nova secagem, prontas para receberem os antígenos.

O antígeno foi feito a partir de Rickettsia spp infectada em cultivo celular, no momento em que a infecção verificada pela coloração de Gimenez (1964), atingiu taxas de 90 a $100 \%$. A partir de uma garrafa de cultivo celular com volume de 150 $\mathrm{cm}^{3}$, foi possível a produção de aproximadamente 60 lâminas com 12 poços cada. Procedeu-se então a raspagem das células juntamente com o meio, com auxílio de um raspador plástico descartável "cell scraper" (Corning Incorpotared) O conteúdo foi colocado em tubo tipo falcon $50 \mathrm{ml}$, e submetido à centrifugação $(3.000 \mathrm{~g}, 5 \mathrm{~min}$., $4^{\circ} \mathrm{C}$ ). O meio foi descartado, e o precipitado ressuspendido em $8 \mathrm{ml}$ de PBS (solução 
fosfato tamponada, $\mathrm{pH} 7,2$ ) contendo $10 \%$ "Soro de Bezerro Bovino" + 0,01\% azida sódica (para desativar as riquétsias). Após uma nova centrifugação $(3.000 \mathrm{~g}, 5$ minutos, $4^{\circ} \mathrm{C}$ ), o sobrenadante foi descartado e uma nova ressuspensão realizada com $8 \mathrm{ml}$ do PBS. Com auxílio de um micro-pipetador multicanal, colocou-se $10 \mu \mathrm{l}$ dessa suspensão em cada poço da lâmina, visando atingir aproximadamente 10.000 células/poço. As lâminas permaneceram dentro do fluxo até a secagem total. Depois, foram submersas em acetona por 10 minutos para fixação do material, secadas e armazenadas a $-70^{\circ} \mathrm{C}$.

\subsubsection{Reação de Imunofluorescência Indireta}

A reação de imunofluorescência indireta (RIFI) foi utilizada para detecção dos títulos de anticorpos anti-R. rickettsii, anti-R. parkeri, anti-R. felis e anti- $R$. bellii nos soros obtidos.

Uma alíquota de soro era diluída em PBS e a seguir depositada sobre a lâmina contendo o antígeno de riquétsia. Após incubação em estufa $\left(37^{\circ} \mathrm{C}, 30\right.$ minutos) a lâmina foi lavada com PBS, seguido de água destilada, ficando em repouso até sua secagem total. À cada lâmina, foi adicionado o conjugado específico (isotiocianato) em diferentes diluições para cada espécie (gambás 1/300; cães 1/400; gatos 1/1.000; eqüinos 1/100 e humanos 1/200). Após nova incubação $\left(37^{\circ} \mathrm{C}, 30\right.$ minutos) e lavagem, a secagem foi feita em câmara escura. A leitura da lâmina era realizada em um microscópio de imunofluorescência. Foram considerados positivos os soros com títulos $\geq 64$. Em seguida, os soros positivos foram diluídos em duas vezes, repetidamente, até se chegar ao último título

verificado. Para cada lâmina, foram utilizados controles padrões, positivos e 
negativos, de acordo com cada espécie animal (HORTA et al., 2004). Os controles positivos e negativos de gambás foram gentilmente cedidos por Celso Eduardo de Souza (SUCEN/SP). Os protocolos utilizados seguiram as recomendações de Walker et al. (1992).

\subsubsection{Extração de DNA}

Procedeu-se extração de DNA a partir do coágulo e/ou sangue total dos diferentes hospedeiros utilizando-se de "kits" comerciais de extração DNeasy® Tissue Kit (Qiagen) e Wizard® Genomic DNA Purification Kit (Promega, USA).

\subsubsection{PCR, Purificação e Sequenciamento de DNA}

A amplificação, revelação, purificação e análise do DNA de riquétsias detectadas a partir do sangue dos mamíferos, foram realizadas de acordo com os procedimentos utilizados para os vetores (itens 3.5 .2 e 3.5.3).

\subsection{CULTIVO CELULAR}

O cultivo celular visa o isolamento, crescimento, replicação e manutenção das riquétsias, objetivando a formação de um banco de amostras, obtenção de controle positivo, produção de anticorpos e a caracterização molecular da cepa. As células permanecem armazenadas a $-80^{\circ} \mathrm{C}$, e são oportunamente descongeladas conforme a necessidade. 


\subsubsection{Células VERO}

A principal linhagem utilizada para cultivo de Rickettsia spp é a de células VERO, provenientes de rim de macaco verde da África. Dentro do fluxo laminar, o repique é realizado a partir da monocamada estabelecida dentro de uma garrafa de cultivo $\left(25 \mathrm{~cm}^{3}\right)$. A monocamada é removida com auxílio de tripsina $(5 \mathrm{ml}$ para cada $3 \mathrm{ml}$ meio). Adiciona-se meio de cultivo "Minimum Essential Medium" (MEM/Invitrogen), acrescido de $5 \%$ de "Soro de Bezerro Bovino" (SBB/HyColne). Homogeneíza-se e, então, o conteúdo é distribuído entre duas outras garrafas. As garrafas com as células VERO são incubadas à temperatura de $37^{\circ} \mathrm{C}$, para formação da monocamada.

\subsubsection{Células C6/36}

Uma linhagem de células de mosquito Aedes albopictus, C6/36 (IGARASHI, 1978), foi mantida no laboratório. O repique é feito semanalmente, com homogeneização da garrafa com meio de cultivo "Leibovitz 15" acrescido de 10\% de SBB. As garrafas com as células C6/36 são incubadas à temperatura de $28^{\circ} \mathrm{C}$, para formação e manutenção da monocamada.

\subsubsection{Isolamento de Rickettsia felis}

Visando o isolamento de R. felis, parte das pulgas colhidas de cães dos municípios de Pedreira foi destinada ao cultivo celular. 
Uma vez estabelecia a linhagem celular (VERO e/ou C6/36), as células foram transferidas das garrafas de cultivo para tubos cilíndricos com fundos chatos, denominados "shell vial", numa concentração aproximada de 200.000 células por tubo (KELLY; RAOULT; MASON, 1991).

As pulgas foram submersas em álcool-iodado por 10 minutos, para eliminar a contaminação externa dos artrópodes. Em seguida, foram submetidas a uma série de lavagens consecutivas com PBS. Procedeu-se a maceração das mesmas com auxílio de um micro-pistilo estéril e 1,0 ml do meio específico para a célula utilizada, com $1 \%$ de antibiótico [penicilina (100 U.I./ml); estreptomicina $(0,1 \mathrm{mg} / \mathrm{ml})]$. Uma alíquota de cada amostra foi separada para realização da PCR e sequenciamento de DNA (itens 3.5.1 e 3.5.2), para confirmação da infecção por $R$. felis. Outra parte foi adicionada ao "shell vial" previamente preenchido pela linhagem celular escolhida (dois dias de incubação).

Em seguida, após a centrifugação $\left(700 \mathrm{~g}, 1\right.$ hora, $\left.22^{\circ} \mathrm{C}\right)$ os tubos foram colocados na estufa à temperatura de $28^{\circ} \mathrm{C}$. Após $48-72$ horas, o meio dos tubos infectados foi trocado, desta vez, por outro sem antibiótico. A troca de meio foi realizada até a detecção de riquétsias através da coloração de fucsina/verde malaquita (GIMENEZ, 1964) nas células do meio a ser desprezado. Neste momento, a monocamada foi coletada e transferida para uma garrafa de cultivo de $25 \mathrm{~cm}^{3}$, também contendo uma monocamada com a mesma linhagem celular, e novamente incubada a $28^{\circ} \mathrm{C}$ (RAOULT et al., 2001). A taxa de infecção celular foi observada a cada 4 dias e uma vez atingindo $\cong 90 \%$, a monocamada foi transferida para uma garrafa de $75 \mathrm{~cm}^{3}$, previamente inoculada com a mesma linhagem celular. Novamente, quando a infecção celular atingiu $\cong 100 \%$, novos repiques foram feitos 
em células não infectadas. Para confirmação e caracterização da cepa isolada, foi realizada PCR e sequenciamento de DNA (itens 3.5.2 e 3.5.3).

\subsection{ANÁLISE ESTATÍSTICA}

A freqüência de pulgas positivas para $R$. felis e de animais reagentes à RIFI frente aos antígeno de Rickettsia rickettsii, R. parkeri, R. felis e R. bellii, de acordo com os dois grupos de municípios estudados, foram comparados utilizando-se o Teste Exato de Fisher, com nível de significância de 5\% $(p<0,05)$. As análises foram realizadas com auxílio do programa SPSS para Windows, versão 9.0 (SPSS, 1999). 


\section{RESULTADOS}

\subsection{CAPTURA E IDENTIFICAÇÃO DE GAMBÁS}

Foram capturados 94 gambás, pertencentes a duas espécies, 65 Didelphis aurita (gambá de orelha-preta, Figura 3a) e 29 Didelphis albiventris (gambá de orelha-branca, Figura 3b), representando $69,1 \%$ e $30,9 \%$ dos animais, respectivamente

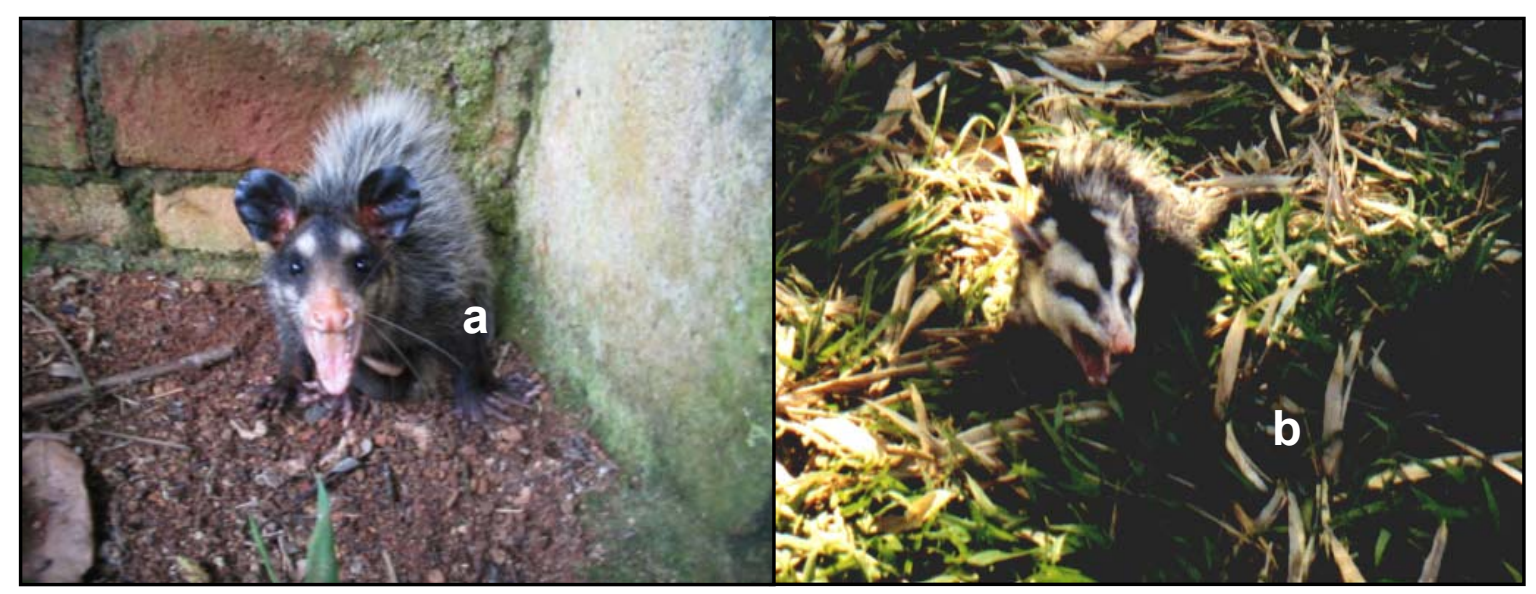

Figura 3 - (a) Didelphis aurita (gambá de orelha preta). Pedreira/SP - 2004; (b) Didelphis albiventris (gambá de orelha branca). Piracicaba/SP - 2003

Durante os trabalhos, outros animais foram capturados acidentalmente, dentre eles 3 marsupiais (Lutreolina crassicaudata, Monodelphis sp, Gracilinanus $\mathrm{sp}), 2$ roedores de médio porte não identificados, 2 roedores de médio porte (Phyllomys sp), 4 roedores de pequeno porte (Akodon sp) e 3 répteis (Tupinambis $\mathrm{sp}$ ), que foram soltos em seguida. Recapturas de gambás ocorreram em Mogi das Cruzes e Pirassununga, e, embora não tenham entrado na contagem total, seus ectoparasitos foram colhidos e analisados. 


\subsection{COLHEITA DE SANGUE}

No quadro 1 , constam os números de amostras de sangue colhidas segundo hospedeiros residentes e/ou freqüentadores dos sítios de capturas.

\begin{tabular}{|c|c|c|c|c|c|c|}
\hline \multirow{2}{*}{ Sangue } & \multicolumn{4}{|c|}{ Grupo 1} & \multirow{2}{*}{$\begin{array}{l}\text { Grupo } 2 \\
\text { Pirassununga }\end{array}$} & \multirow{2}{*}{ Total } \\
\hline & Pedreira & Mogi das Cruzes & Piracicaba & São Paulo & & \\
\hline Humanos & 52 & 21 & 69 & 68 & 28 & 238 \\
\hline Eqüinos & 20 & 5 & 21 & 20 & 19 & 85 \\
\hline Cães & 19 & 13 & 7 & 11 & 5 & 55 \\
\hline Gatos & 3 & 3 & 7 & 6 & 6 & 25 \\
\hline Gambás & 14 & 16 & 17 & 35 & 12 & 94 \\
\hline Total & 108 & 58 & 121 & 140 & 70 & 496 \\
\hline
\end{tabular}

Quadro 1 - Número de amostras de sangue colhidas por município estudado

\subsection{COLHEITA DE ECTOPARASITOS}

\subsubsection{Pulgas}

Foram colhidas 312 pulgas parasitando gambás. A razão sexual de C. felis felis encontrada parasitando gambás foi de 1 macho para 3,2 fêmeas; e a razão sexual das pulgas da Família Rhopalopsyllidae foi de 1 macho para cada 1 fêmea. Foram identificadas as seguintes espécies: Adoratopsylla (Adoratopsylla) antiquorum antiquorum (Família Ctenophthalmidae); Ctenocephalides felis felis (Família Pulicidae); Polygenis (Neopolygenis) atopus, Polygenies (Polygenis) roberti roberti, Polygenis (Polygenis) tripus, Polygenis (Polygenis) rimatus, Rhopalopsyllus lugubris lugubris e Rhopalopsyllus lutzi lutzi (Família Rhopalopsyllidae). O número de pulgas colhidas por localidade está listado na tabela 2. 
Tabela 2 - Pulgas colhidas sobre gambás em municípios do Estado de São Paulo, 2003-2006

\begin{tabular}{|c|c|c|c|c|c|c|}
\hline Espécie & Pedreira & Mogi das Cruzes & Piracicaba & São Paulo & Pirassununga & Total \\
\hline A. ant ${ }^{1}$ & 0 & 1 & 0 & 0 & 0 & 1 \\
\hline C.fel ${ }^{2}$ & 37 & 36 & 11 & 60 & 0 & 144 \\
\hline P.ato ${ }^{3}$ & 1 & 61 & 0 & 0 & 37 & 99 \\
\hline P.rob ${ }^{4}$ & 0 & 7 & 0 & 0 & 1 & 8 \\
\hline P.tri ${ }^{5}$ & 0 & 2 & 1 & 0 & 1 & 4 \\
\hline P.rim ${ }^{6}$ & 0 & 1 & 0 & 0 & 0 & 1 \\
\hline$R . \operatorname{lug}^{7}$ & 3 & 0 & 0 & 0 & 0 & 3 \\
\hline R.lut $^{8}$ & 16 & 0 & 12 & 0 & 24 & 52 \\
\hline Total & 57 & 108 & 24 & 60 & 63 & 312 \\
\hline
\end{tabular}

${ }^{1}$ Adoratopsylla (Adoratopsylla) antiquorum antiquorum, ${ }^{2}$ Ctenocephalides felis felis, ${ }^{3}$ Polygenis (Neopolygenis) atopus, ${ }^{4}$ Polygenies (Polygenis) roberti roberti, ${ }^{5}$ Polygenis (Polygenis) tripus, ${ }^{6}$ Polygenis (Polygenis) rimatus, ${ }^{7}$ Rhopalopsyllus lugubris lugubris, ${ }^{8}$ Rhopalopsyllus lutzi lutzi.

Foram colhidas 278 pulgas parasitando cães e gatos. Em relação às pulgas colhidas dos cães, todos os exemplares encontrados pertenciam à espécie C. felis felis (1 machos/ 2,5 fêmeas); enquanto em gatos observou-se a presença de duas espécies: $C$. felis felis (1 macho / 1,8 fêmeas) e $R$. lutzi lutzi ( 1 macho / 1 fêmea) em gatos (Tabela 3).

Tabela 3 - Pulgas colhidas sobre cães e gatos em municípios do Estado de São Paulo, 2003-2006

\begin{tabular}{cccccccc}
\hline \multicolumn{2}{c}{ Espécie } & Pedreira & Mogi das Cruzes & Piracicaba & São Paulo & Pirassununga & Total \\
\hline Cão & $C . f e l^{I}$ & 74 & 25 & 46 & 30 & 37 & $\mathbf{2 1 2}$ \\
Gato & $C . f e l^{l}$ & 6 & 6 & 6 & 17 & 24 & $\mathbf{5 9}$ \\
Gato & R.lut ${ }^{2}$ & 1 & 0 & 1 & 0 & 5 & $\mathbf{7}$ \\
\hline \multicolumn{2}{c}{ Total } & $\mathbf{8 1}$ & $\mathbf{3 1}$ & $\mathbf{5 3}$ & $\mathbf{4 7}$ & $\mathbf{6 6}$ & $\mathbf{2 7 8}$ \\
\hline
\end{tabular}

${ }^{1}$ Ctenocephalides felis felis, ${ }^{2}$ Rhopalopsyllus lutzi lutzi

\subsubsection{Carrapatos}

Foram colhidos 709 carrapatos em gambás, pertencentes aos gêneros Amblyomma e Ixodes, relacionados na tabela 4. Dentre os carrapatos adultos 
colhidos dos gambás, foram identificados Ixodes loricatus $(98,2 \%)$ e Amblyomma cajennense $(1,8 \%)$.

A criação de carrapatos em laboratório, colhidos em fase imatura e mantidos até adultos possibilitou o diagnóstico específico de 79 exemplares de Amblyomma cajennense (a partir de 27 larvas e 52 ninfas de Amblyomma sp) e de 23 Amblyomma dubitatum (a partir de 18 larvas e 5 ninfas de Amblyomma sp).

Tabela 4 - Carrapatos colhidos sobre gambás em municípios do Estado de São Paulo, 2003-2006

\begin{tabular}{llcccccc}
\hline \multicolumn{2}{c}{ Estádio/Espécie/Local } & Pedreira & $\begin{array}{c}\text { Mogi } \\
\text { Cruzes }\end{array}$ & Piracicaba & $\begin{array}{c}\text { São } \\
\text { Paulo }\end{array}$ & Pirassununga & Total \\
\hline $\begin{array}{l}\text { Larva } \\
(\mathrm{n}=222)\end{array}$ & $\begin{array}{l}\text { Amblyomma } \text { sp } \\
\text { A. cajennense }\end{array}$ & 1 & 21 & 136 & 0 & 19 & $\mathbf{1 7 7}$ \\
& A. dubitatum & 0 & 0 & 27 & 0 & 0 & $\mathbf{2 7}$ \\
Ninfa & Amblyomma sp & 35 & 3 & 254 & 0 & 26 & $\mathbf{1 8}$ \\
$(\mathrm{n}=375)$ & A. cajennense & 1 & 0 & 51 & 0 & 0 & $\mathbf{5 2}$ \\
& A. dubitatum & 0 & 3 & 2 & 0 & 0 & $\mathbf{5}$ \\
$\begin{array}{l}\text { Adulto } \\
(\mathrm{n}=112)\end{array}$ & Ixodes loricatus & 0 & 73 & 0 & 6 & 31 & $\mathbf{1 1 0}$ \\
\hline Total & & 0 & 0 & 2 & 0 & 0 & $\mathbf{2}$ \\
\hline
\end{tabular}

Dos cães, foram colhidos 115 carrapatos com predominância da espécie Rhipicephalus sanguineus sobre as do gênero Amblyomma (Tabela 5). Dos dez exemplares colhidos dos gatos, um foi identificado como Rhipicephalus sanguineus e os demais como carrapatos do gênero Amblyomma (Tabela 6). 
Tabela 5 - Carrapatos colhidos sobre cães em municípios do Estado de São Paulo, 2003-2006

\begin{tabular}{|c|c|c|c|c|c|c|c|}
\hline \multicolumn{2}{|c|}{ Estádio/Espécie/Local } & \multirow{2}{*}{$\begin{array}{c}\text { Pedreira } \\
3 \\
3\end{array}$} & \multirow{2}{*}{$\begin{array}{c}\text { Mogi } \\
\text { Cruzes } \\
0\end{array}$} & \multirow{2}{*}{$\begin{array}{c}\text { Piracicaba } \\
0\end{array}$} & \multirow{2}{*}{$\begin{array}{c}\text { São } \\
\text { Paulo }\end{array}$} & \multirow{2}{*}{$\begin{array}{c}\text { Pirassununga } \\
0 \\
0\end{array}$} & \multirow{2}{*}{$\begin{array}{c}\text { Total } \\
3\end{array}$} \\
\hline $\begin{array}{l}\text { Larva } \\
(n=3)\end{array}$ & A. cajennense & & & & & & \\
\hline $\begin{array}{l}\text { Ninfa } \\
(n=27)\end{array}$ & $\begin{array}{l}\text { A. cajennense } \\
\text { Amblyomma sp }\end{array}$ & $\begin{array}{c}26 \\
1\end{array}$ & $\begin{array}{l}0 \\
0\end{array}$ & $\begin{array}{l}0 \\
0\end{array}$ & $\begin{array}{l}0 \\
0\end{array}$ & $\begin{array}{l}0 \\
0\end{array}$ & $\begin{array}{c}26 \\
1\end{array}$ \\
\hline $\begin{array}{l}\text { Adulto } \\
(\mathrm{n}=\mathbf{8 5})\end{array}$ & $\begin{array}{l}\text { A. cajennense } \\
\text { A. aureolatum } \\
\text { Rhipicephalus } \\
\text { sanguineus }\end{array}$ & $\begin{array}{c}3 \\
0 \\
61\end{array}$ & $\begin{array}{c}0 \\
15 \\
0\end{array}$ & $\begin{array}{l}1 \\
0 \\
4\end{array}$ & $\begin{array}{l}0 \\
1 \\
0\end{array}$ & $\begin{array}{l}0 \\
0 \\
0\end{array}$ & $\begin{array}{c}4 \\
16 \\
65\end{array}$ \\
\hline Total & & 94 & 15 & 5 & 1 & $\overline{\mathbf{0}}$ & 115 \\
\hline
\end{tabular}

Tabela 6 - Carrapatos colhidos sobre gatos em municípios do Estado de São Paulo, 2003-2006

\begin{tabular}{lccccccc}
\hline Estádio/Espécie/Local & Pedreira & $\begin{array}{c}\text { Mogi } \\
\text { Cruzes }\end{array}$ & Piracicaba & $\begin{array}{c}\text { São } \\
\text { Paulo }\end{array}$ & Pirassununga & Total \\
\hline $\begin{array}{l}\text { Larva } \\
(\mathbf{n}=\mathbf{3})\end{array}$ & A. cajennense & 3 & 0 & 0 & 0 & 0 & 3 \\
& & & & & & \\
$\begin{array}{l}\text { Ninfa } \\
(\mathbf{n}=\mathbf{6})\end{array}$ & $\begin{array}{l}\text { Amblyomma sp } \\
\begin{array}{l}\text { Rhipicephalus } \\
\text { sanguineus }\end{array}\end{array}$ & 0 & 0 & 5 & 0 & 0 & 5 \\
$\begin{array}{l}\text { Adulto } \\
(\mathbf{n}=\mathbf{1})\end{array}$ & A. aureolatum & 0 & 1 & 0 & 0 & 0 & 1 \\
\hline Total & & $\mathbf{4}$ & $\mathbf{1}$ & $\mathbf{5}$ & $\mathbf{0}$ & $\mathbf{0}$ & $\mathbf{1 0}$ \\
\hline
\end{tabular}

\subsection{PESQUISA DE RIQUÉTSIAS EM POTENCIAIS VETORES}

\subsubsection{Reação em Cadeia pela Polimerase (PCR)}

As pulgas colhidas sobre potenciais hospedeiros de riquétsias foram analisadas individualmente e apresentaram positividade para o gene gltA: 71 $(22,7 \%)$ colhidas sobre gambás (Tabela 7$) ; 89$ (42,0\%) sobre cães e 25 (37,9\%) sobre gatos (Tabelas 8). À análise estatística, houve associação entre a positividade 
de $R$. felis em pulgas de gambás e cães em áreas endêmicas (grupo 1) frente às pulgas destes hospedeiros da área não-endêmica (grupo 2) $(p<0,05)$.

Tabela 7 - Pulgas positivas na PCR, para o gene gltA, colhidas sobre gambás capturados no Estado de São Paulo

\begin{tabular}{lcccccc}
\hline Espécie & Pedreira & Mogi das Cruzes & Piracicaba & São Paulo & Pirassununga & Total \\
\hline \multirow{2}{*}{ C.fel } & 37 & 36 & 11 & 60 & 0 & $\mathbf{1 4 4}$ \\
& $(19)$ & $(12)$ & $(8)$ & $(27)$ & $(0)$ & $\mathbf{( 6 6 )}$ \\
P.ato $^{2}$ & 1 & 61 & 0 & 0 & 37 & $\mathbf{9 9}$ \\
& $(0)$ & $(2)$ & $(0)$ & $(0)$ & $(3)$ & $\mathbf{( 5 )}$ \\
\hline \multirow{2}{*}{ Total $^{*}$} & $\mathbf{3 8}$ & $\mathbf{9 7}$ & $\mathbf{1 1}$ & $\mathbf{6 0}$ & $\mathbf{3 7}$ & $\mathbf{2 4 3}$ \\
& $\mathbf{( 1 9 )}$ & $\mathbf{( 1 4 )}$ & $\mathbf{( 8 )}$ & $\mathbf{( 2 7 )}$ & $\mathbf{( 3 )}$ & $\mathbf{( 7 1 )}$ \\
\hline
\end{tabular}

* $\mathrm{n}(\mathrm{p}): \mathrm{n}$ = número de indivíduos examinados; $\mathrm{p}=$ número de indivíduos positivos;

${ }^{1}$ Ctenocephalides felis felis, ${ }^{2}$ Polygenis (Neopolygenis) atopus

Tabela 8 - Pulgas positivas na PCR, para o gene gltA, colhidas sobre cães e gatos no Estado de São Paulo

\begin{tabular}{|c|c|c|c|c|c|c|}
\hline Espécie & Pedreira & Mogi das Cruzes & Piracicaba & São Paulo & Pirassununga & Total \\
\hline C.fel ${ }^{I}$ & $\begin{array}{c}74 \\
(39)\end{array}$ & $\begin{array}{c}25 \\
(10)\end{array}$ & $\begin{array}{c}46 \\
(21)\end{array}$ & $\begin{array}{c}30 \\
(14)\end{array}$ & $\begin{array}{l}37 \\
(5)\end{array}$ & $\begin{array}{l}212 \\
(89)\end{array}$ \\
\hline Gato $\quad$ C.fel ${ }^{l}$ & $\begin{array}{c}6 \\
(5)\end{array}$ & $\begin{array}{c}6 \\
(3)\end{array}$ & $\begin{array}{c}6 \\
(3)\end{array}$ & $\begin{array}{l}17 \\
(5)\end{array}$ & $\begin{array}{l}24 \\
(9)\end{array}$ & $\begin{array}{c}59 \\
(25)\end{array}$ \\
\hline Total & $\begin{array}{c}81 \\
(44)\end{array}$ & $\begin{array}{c}31 \\
(13)\end{array}$ & $\begin{array}{c}53 \\
(24) \\
\end{array}$ & $\begin{array}{c}47 \\
(19)\end{array}$ & $\begin{array}{c}66 \\
(14)\end{array}$ & $\begin{array}{r}278 \\
(114) \\
\end{array}$ \\
\hline
\end{tabular}

${ }^{*} \mathrm{n}(\mathrm{p}): \mathrm{n}=$ número de indivíduos examinados; $\mathrm{p}=$ número de indivíduos positivos;

${ }^{1}$ Ctenocephalides felis felis

Foram processados pela PCR, 709 carrapatos colhidos sobre gambás dos quais 81 apresentaram positividade para o gene gltA (Tabela 9). Sobre os cães e gatos, 115 e 10 carrapatos, respectivamente, mostraram-se negativos à PCR. 
Tabela 9 - Carrapatos positivos na PCR, para o gene gltA, colhidos sobre gambás capturados no Estado de São Paulo

\begin{tabular}{|c|c|c|c|c|c|c|}
\hline Estádio/Espécie/Local & Pedreira & Mogi Cruzes & Piracicaba & São Paulo & Pirassununga & Total \\
\hline \multirow{2}{*}{ Amblyomma sp } & $36(1)$ & $24(1)$ & $390(6)$ & $0(0)$ & $45(3)$ & 495 (11) \\
\hline & $2,8 \%$ & $4,2 \%$ & $1,5 \%$ & $0 \%$ & $6,7 \%$ & $2,2 \%$ \\
\hline \multirow{2}{*}{ A. cajennense } & $1(0)$ & $0(0)$ & $80(1)$ & $0(0)$ & $0(0)$ & 81 (1) \\
\hline & $0 \%$ & $0 \%$ & $1,25 \%$ & $0 \%$ & $0 \%$ & $1,2 \%$ \\
\hline \multirow{2}{*}{ A. dubitatum } & $0(0)$ & $12(1)$ & $9(1)$ & $0(0)$ & $2(0)$ & $23(2)$ \\
\hline & $0 \%$ & $8,3 \%$ & $11,1 \%$ & $0 \%$ & $0 \%$ & $8,7 \%$ \\
\hline \multirow{2}{*}{ Ixodes loricatus } & $0(0)$ & $73(38)$ & $0(0)$ & $6(6)$ & $31(23)$ & $110(67)$ \\
\hline & $0 \%$ & $52,0 \%$ & $0 \%$ & $100 \%$ & $74,2 \%$ & $60,9 \%$ \\
\hline \multirow{2}{*}{ Total } & 37 & 109 & 479 & 6 & 78 & $709(81)$ \\
\hline & (1) & (40) & (8) & (6) & (26) & $11,4 \%$ \\
\hline
\end{tabular}

\subsubsection{Sequenciamento de DNA}

Pulgas colhidas de gambás, 66 C. felis felis (45,8\% desta espécie) e quatro Polygenis (Neopolygenis) atopus (4,0\% desta espécie), positivas na PCR (gene gltA), foram submetidas ao sequenciamento de DNA, gerando seqüências iguais entre si. Os fragmentos analisados apresentaram $100 \%$ de identidade com a seqüência de nucleotídeos de $R$. felis, cepa da Califórnia/EUA (AF210692) e 98,6\% de identidade à cepa de $R$. felis oriunda da Tailândia (AF516333.1), ambas disponibilizadas no GenBank. Uma pulga $P$. (N.) atopus (1,0\%), também de gambá, apresentou fragmento de DNA riquetsial com seqüência de nucleotídeos mostrando 100\% de identidade à Rickettsia bellii.

Em relação às pulgas C. felis felis colhidas de cães e gatos, 89 (42,0\%) e 25 $(42,4 \%)$, respectivamente, foram seqüenciadas, apresentando a mesma identidade com $R$. felis, das pulgas de gambás. 
As seqüências obtidas, a partir de carrapatos de gambás, foram analisadas e comparadas com seqüências do Genbank, apresentaram 99,7\% de identidade à Rickettsia bellii (U59716.1, AY362703.1) (65 I. loricatus, 2 A. dubitatum, 3 pools de larvas Amblyomma sp, 2 pools de ninfas de Amblyomma sp); $100 \%$ de identidade a R. felis (CP000053.1, AF210692.1,) (2 larvas e 2 ninfas de Amblyomma sp e 2 adultos de I. loricatus); 100,0\% de identidade à Rickettsia amblyommii (AY375163.1) (1 pool de ninfas de Amblyomma sp). Outras duas amostras obtiveram identidade à Rickettsia sp (2 pools de ninfas de Amblyomma sp) (Tabela 10).

Tabela 10 - Amostras de DNA de riquétsias seqüenciadas em carrapatos positivos na $\mathrm{PCR}$, para o gene gltA, colhidos sobre gambás capturados no Estado de São Paulo

\begin{tabular}{|c|c|c|c|c|}
\hline \multicolumn{2}{|c|}{ Amostras } & Carrapato & Seqüências & Município \\
\hline 1 pool & 4 ninfas & Amblyomma $\mathrm{sp}$ & 1 Rickettsia bellii & Pedreira \\
\hline 38 adultos & 38 adultos & Ixodes loricatus & 38 Rickettsia bellii & Mogi das Cruzes \\
\hline 1 ninfa* & 1 adulto & A. dubitatum & 1 Rickettsia bellii & Mogi das Cruzes \\
\hline 1 larva & 1 larva & Amblyomma $\mathrm{sp}$ & 1 Rickettsia felis & Mogi das Cruzes \\
\hline 1 pool & 11 larvas & Amblyomma $\mathrm{sp}$ & 1 Rickettsia bellii & Piracicaba \\
\hline 1 pool & 10 larvas & Amblyomma $\mathrm{sp}$ & 1 Rickettsia bellii & Piracicaba \\
\hline 1 pool & 5 larvas & Amblyomma $\mathrm{sp}$ & 1 Rickettsia bellii & Piracicaba \\
\hline 1 pool & 5 ninfas & Amblyomma $\mathrm{sp}$ & 1 Rickettsia $\mathrm{sp}$ & Piracicaba \\
\hline 1 pool & 5 ninfas & Amblyomma $\mathrm{sp}$ & 1 Rickettsia amblyommii & Piracicaba \\
\hline 1 pool & 5 ninfas & Amblyomma $\mathrm{sp}$ & 1 Rickettsia bellii & Piracicaba \\
\hline 1 ninfa* & 1 adulto & A. dubitatum & 1 Rickettsia bellii & Piracicaba \\
\hline 1 ninfa* & 1 adulto & A. cajennense & 1 Rickettsia $\mathrm{sp}$ & Piracicaba \\
\hline 6 adultos & 6 adultos & Ixodes loricatus & 6 Rickettsia bellii & São Paulo \\
\hline 21 adultos & 21 adultos & Ixodes loricatus & 21 Rickettsia bellii & Pirassununga \\
\hline 2 adultos & 2 adultos & Ixodes loricatus & 2 Rickettsia felis & Pirassununga \\
\hline 1 larvas & 1 larvas & Amblyomma sp & 1 Rickettsia felis & Pirassununga \\
\hline 2 ninfas & 2 ninfas & Amblyomma $\mathrm{sp}$ & 2 Rickettsia felis & Pirassununga \\
\hline
\end{tabular}

${ }^{*}$ ninfas que realizaram ecdise para adulto 
Tabela 11 - Grau de identidade calculado para cada par de seqüências de nucleotídeos, entre as amostras de pulgas obtidas, através do sequenciamento de DNA (gene gltA, 350 pb) e seqüências de Rickettsia spp do GenBank

\begin{tabular}{|c|c|c|c|c|c|c|c|c|c|c|c|c|c|c|c|c|}
\hline & $\begin{array}{c}R \\
a k a\end{array}$ & $\begin{array}{c}R \\
a m b\end{array}$ & $\begin{array}{c}R \\
\text { aus }\end{array}$ & $\begin{array}{c}R \\
\text { bel }\end{array}$ & $\begin{array}{c}R \\
\text { can }\end{array}$ & $\begin{array}{c}R \\
\text { con }\end{array}$ & $\begin{array}{c}R \\
f e l\end{array}$ & $\begin{array}{c}R \\
\text { hon }\end{array}$ & $\begin{array}{c}R \\
\text { jap }\end{array}$ & $\begin{array}{c}R \\
\text { par }\end{array}$ & $\begin{array}{c}R \\
\text { pro }\end{array}$ & $\begin{array}{c}R \\
r h i\end{array}$ & $\begin{array}{l}R \\
r i c\end{array}$ & $\begin{array}{c}R \\
\text { typ }\end{array}$ & $\begin{array}{c}R \mathrm{Rel} \\
\mathrm{A} 1\end{array}$ & $\begin{array}{c}R \text { bel } \\
\text { A2 }\end{array}$ \\
\hline R akari $^{1}$ & 1,000 & 0,908 & 0,968 & 0,840 & 0,845 & 0,928 & 0,948 & 0,925 & 0,917 & 0,925 & 0,882 & 0,925 & 0,92 & 0,882 & 0,948 & 0,837 \\
\hline$R$ amblyommi ${ }^{2}$ & - & 1,000 & 0,911 & 0,860 & 0,871 & 0,980 & 0,914 & 0,977 & 0,971 & 0,977 & 0,911 & 0,971 & 0,971 & 0,917 & 0,914 & 0,857 \\
\hline$R$ australis ${ }^{3}$ & - & - & 1,000 & 0,842 & 0,842 & 0,931 & 0,951 & 0,928 & 0,920 & 0,928 & 0,885 & 0,928 & 0,922 & 0,891 & 0,951 & 0,840 \\
\hline$R$ bellit $i^{4}$ & - & - & - & 1,000 & 0,845 & 0,862 & 0,845 & 0,862 & 0,860 & 0,865 & 0,842 & 0,854 & 0,854 & 0,857 & 0,845 & 0,997 \\
\hline$R$ canadensis $^{5}$ & - & - & - & - & 1,000 & 0,880 & 0,871 & 0,877 & 0,877 & 0,877 & 0,857 & 0,871 & 0,877 & 0,865 & 0,871 & 0,842 \\
\hline$R$ conorii $^{6}$ & - & - & - & - & - & 1,000 & 0,934 & 0,997 & 0,988 & 0,997 & 0,928 & 0,991 & 0,991 & 0,934 & 0,934 & 0,860 \\
\hline$R$ felis $^{7}$ & - & - & - & - & - & - & 1,000 & 0,931 & 0,922 & 0,931 & 0,888 & 0,931 & 0,925 & 0,888 & 1,000 & 0,842 \\
\hline$R$ honei $^{8}$ & - & - & - & - & - & - & - & 1,000 & 0,985 & 0,994 & 0,925 & 0,988 & 0,988 & 0,931 & 0,931 & 0,860 \\
\hline$R$ japonica $^{9}$ & - & - & - & - & - & - & - & - & 1,000 & 0,985 & 0,922 & 0,980 & 0,980 & 0,928 & 0,922 & 0,857 \\
\hline$R$ parkeri $i^{10}$ & - & - & - & - & - & - & - & - & - & 1,000 & 0,925 & 0,988 & 0,988 & 0,931 & 0,931 & 0,862 \\
\hline$R$ prowazekii ${ }^{11}$ & - & - & - & - & - & - & - & - & - & - & 1,000 & 0,925 & 0,92 & 0,951 & 0,888 & 0,840 \\
\hline$R$ rhipicephali ${ }^{12}$ & - & - & - & - & - & - & - & - & - & - & - & 1,000 & 0,982 & 0,931 & 0,931 & 0,851 \\
\hline R rickettsii ${ }^{13}$ & - & - & - & - & - & - & - & - & - & - & - & - & 1,000 & 0,925 & 0,925 & 0,851 \\
\hline R. typhi ${ }^{14}$ & - & - & - & - & - & - & - & - & - & - & - & - & - & 1,000 & 0,888 & 0,854 \\
\hline R. felis A1 & - & - & - & - & - & - & - & - & - & - & - & - & - & - & 1,000 & 0,842 \\
\hline$R$ bellii $A 2$ & - & - & - & - & - & - & - & - & - & - & - & - & - & - & - & 1,000 \\
\hline
\end{tabular}

GenBank: ${ }^{1}$ U59717.1, ${ }^{2}$ AY375163.1, ${ }^{3}$ U59718.1, ${ }^{4} U 59716.1,{ }^{5} U 59713.1,{ }^{6} U 59730.1$, ${ }^{7} \mathrm{AF} 210692.1,{ }^{8} \mathrm{AF} 018074,{ }^{9} \mathrm{U} 59724.1, \quad{ }^{10} \mathrm{U} 59732.1, \quad{ }^{11} \mathrm{U} 59715.1,{ }^{12} \mathrm{U} 59721.1$, ${ }^{13}$ U59729.1, ${ }^{14}$ U59714.1

Tabela 12 - Grau de identidade calculado para cada par de seqüências de nucleotídeos, entre as amostras de carrapatos obtidas, através do sequenciamento de DNA (gene gltA, 350 pb) e seqüências de Rickettsia spp do GenBank

\begin{tabular}{|c|c|c|c|c|c|c|c|c|c|c|c|c|c|c|c|c|}
\hline & $\begin{array}{c}R \\
a k a\end{array}$ & $\begin{array}{c}R \\
a m b\end{array}$ & $\begin{array}{c}R \\
\text { aus }\end{array}$ & $\begin{array}{c}R \\
\text { bel }\end{array}$ & $\begin{array}{c}R \\
\text { can }\end{array}$ & $\begin{array}{c}R \\
\text { con }\end{array}$ & $\begin{array}{c}R \\
f e l\end{array}$ & $\begin{array}{c}R \\
\text { hon }\end{array}$ & $\begin{array}{c}R \\
\text { par }\end{array}$ & $\begin{array}{c}R \\
\text { pro }\end{array}$ & $\begin{array}{c}R \\
r h i\end{array}$ & $\begin{array}{c}R \\
r i c\end{array}$ & $\begin{array}{c}R \\
\text { typ }\end{array}$ & $\begin{array}{c}R \mathrm{fel} \\
\mathrm{A} 3\end{array}$ & $\begin{array}{c}R s p \\
\text { A4 }\end{array}$ & $\begin{array}{c}R \text { bel } \\
\text { A2 }\end{array}$ \\
\hline R akari ${ }^{1}$ & 1,000 & 0,908 & 0,968 & 0,840 & 0,845 & 0,928 & 0,948 & 0,925 & 0,925 & 0,882 & 0,925 & 0,920 & 0,882 & 0,948 & 0,908 & 0,837 \\
\hline$R$ amblyommi $i^{2}$ & - & 1,000 & 0,911 & 0,860 & 0,871 & 0,980 & 0,914 & 0,977 & 0,977 & 0,911 & 0,971 & 0,971 & 0,917 & 0,914 & 1,000 & 0,857 \\
\hline$R$ australis ${ }^{3}$ & - & - & 1,000 & 0,842 & 0,842 & 0,931 & 0,951 & 0,928 & 0,928 & 0,885 & 0,928 & 0,922 & 0,891 & 0,951 & 0,911 & 0,840 \\
\hline$R$ bellii ${ }^{4}$ & - & - & - & 1,000 & 0,845 & 0,862 & 0,845 & 0,862 & 0,865 & 0,842 & 0,854 & 0,854 & 0,857 & 0,845 & 0,86 & 0,997 \\
\hline$R$ canadensis $^{5}$ & - & - & - & - & 1,000 & 0,880 & 0,871 & 0,877 & 0,877 & 0,857 & 0,871 & 0,877 & 0,865 & 0,871 & 0,871 & 0,842 \\
\hline$R$ conorii $^{6}$ & - & - & - & - & - & 1,000 & 0,934 & 0,997 & 0,997 & 0,928 & 0,991 & 0,991 & 0,934 & 0,934 & 0,98 & 0,860 \\
\hline$R$ felis $^{7}$ & - & - & - & - & - & - & 1,000 & 0,931 & 0,931 & 0,888 & 0,931 & 0,925 & 0,888 & 1,000 & 0,914 & 0,842 \\
\hline R honei ${ }^{8}$ & - & - & - & - & - & - & - & 1,000 & 0,994 & 0,925 & 0,988 & 0,988 & 0,931 & 0,931 & 0,977 & 0,860 \\
\hline$R$ parkeri ${ }^{9}$ & - & - & - & - & - & - & - & - & 1,000 & 0,925 & 0,988 & 0,988 & 0,931 & 0,931 & 0,977 & 0,862 \\
\hline$R$ prowazekii ${ }^{10}$ & - & - & - & - & - & - & - & - & - & 1,000 & 0,925 & 0,920 & 0,951 & 0,888 & 0,911 & 0,840 \\
\hline R rhipicephali ${ }^{11}$ & - & - & - & - & - & - & - & - & - & - & 1,000 & 0,982 & 0,931 & 0,931 & 0,971 & 0,851 \\
\hline R rickettsii ${ }^{12}$ & - & - & - & - & - & - & - & - & - & - & - & 1,000 & 0,925 & 0,925 & 0,971 & 0,851 \\
\hline R. typhi $i^{3}$ & - & - & - & - & - & - & - & - & - & - & - & - & 1,000 & 0,888 & 0,917 & 0,854 \\
\hline R. felis A3 & - & - & - & - & - & - & - & - & - & - & - & - & - & 1,000 & 0,914 & 0,842 \\
\hline$R \mathrm{sp} \mathrm{A4}$ & - & - & - & - & - & - & - & - & - & - & - & - & - & - & 1,000 & 0,857 \\
\hline$R$ bellii $\mathrm{A} 5^{14}$ & - & - & - & - & - & - & - & - & - & - & - & - & - & - & - & 1,000 \\
\hline
\end{tabular}

GenBank: ${ }^{1} \mathrm{U} 59717.1,{ }^{2} \mathrm{AY} 375163.1,{ }^{3} \mathrm{U} 59718.1,{ }^{4} \mathrm{U} 59716.1,{ }^{5} \mathrm{U} 59713.1,{ }^{6} \mathrm{U} 59730.1$, ${ }^{7} \mathrm{AF} 210692.1, \quad{ }^{8} \mathrm{AF} 018074, \quad{ }^{9} \mathrm{U} 59732.1, \quad{ }^{10} \mathrm{U} 59715.1, \quad{ }^{11} \mathrm{U} 59721.1, \quad{ }^{12} \mathrm{U} 59729.1$, ${ }^{13} \mathrm{U} 59714.1,{ }^{14} \mathrm{DQ} 146481.1$ 
Tabela 13 - Grau de identidade calculado para cada par de seqüências de nucleotídeos, entre uma amostra pool de carrapatos Amblyomma spp colhida sobre gambá, através do sequenciamento de DNA (gene gltA, 350 pb) e seqüências de Rickettsia spp do GenBank

\begin{tabular}{|c|c|c|c|c|c|c|c|c|c|c|c|c|c|c|c|c|}
\hline & $\begin{array}{c}R \\
a k a\end{array}$ & $\begin{array}{c}R \\
a m b\end{array}$ & $\begin{array}{c}R \\
\text { aus }\end{array}$ & $\begin{array}{c}R \\
b e l\end{array}$ & $\begin{array}{c}R \\
\text { can }\end{array}$ & $\begin{array}{c}R \\
\text { con }\end{array}$ & $\begin{array}{c}R \\
f e l\end{array}$ & $\begin{array}{c}R \\
\text { hon }\end{array}$ & $\begin{array}{c}R \\
\text { jap }\end{array}$ & $\begin{array}{c}R \\
p a r\end{array}$ & $\begin{array}{c}R \\
\text { pro }\end{array}$ & $\begin{array}{c}R \\
r h i\end{array}$ & $\begin{array}{c}R \\
\text { ric }\end{array}$ & $\begin{array}{c}R \\
\text { sib }\end{array}$ & $\begin{array}{c}R \\
\text { typ }\end{array}$ & $\begin{array}{c}R \mathrm{sp} \\
\mathrm{A6}\end{array}$ \\
\hline$R$ akari ${ }^{1}$ & 1,000 & 0,908 & 0,968 & 0,840 & 0,845 & 0,928 & 0,948 & 0,925 & 0,917 & 0,925 & 0,882 & 0,925 & 0,920 & 0,925 & 0,882 & 0,908 \\
\hline$R$ amblyommi ${ }^{2}$ & - & 1,000 & 0,911 & 0,860 & 0,871 & 0,980 & 0,914 & 0,977 & 0,971 & 0,977 & 0,911 & 0,971 & 0,971 & 0,977 & 0,917 & 0,960 \\
\hline$R$ australis ${ }^{3}$ & - & - & 1,000 & 0,842 & 0,842 & 0,931 & 0,951 & 0,928 & 0,92 & 0,928 & 0,885 & 0,928 & 0,922 & 0,928 & 0,891 & 0,911 \\
\hline R bellii ${ }^{4}$ & - & - & - & 1,000 & 0,845 & 0,862 & 0,845 & 0,862 & 0,860 & 0,865 & 0,842 & 0,854 & 0,854 & 0,865 & 0,857 & 0,877 \\
\hline$R$ canadensis ${ }^{5}$ & - & - & - & - & 1,000 & 0,880 & 0,871 & 0,877 & 0,877 & 0,877 & 0,857 & 0,871 & 0,877 & 0,877 & 0,865 & 0,871 \\
\hline$R$ conorii $^{6}$ & - & - & - & - & - & 1,000 & 0,934 & 0,997 & 0,988 & 0,997 & 0,928 & 0,991 & 0,991 & 0,997 & 0,934 & 0,980 \\
\hline$R$ felis $^{7}$ & - & - & - & - & - & - & 1,000 & 0,931 & 0,922 & 0,931 & 0,888 & 0,931 & 0,925 & 0,931 & 0,888 & 0,914 \\
\hline$R$ honel ${ }^{8}$ & - & - & - & - & - & - & - & 1,000 & 0,985 & 0,994 & 0,925 & 0,988 & 0,988 & 0,994 & 0,931 & 0,980 \\
\hline$R$ japonica $^{9}$ & - & - & - & - & - & - & - & - & 1,000 & 0,985 & 0,922 & 0,980 & 0,980 & 0,985 & 0,928 & 0,968 \\
\hline$R$ parkeri ${ }^{10}$ & - & - & - & - & - & - & - & - & - & 1,000 & 0,925 & 0,988 & 0,988 & 1,000 & 0,931 & 0,977 \\
\hline$R$ prowazekii'11 & - & - & - & - & - & - & - & - & - & - & 1,000 & 0,925 & 0,920 & 0,925 & 0,951 & 0,914 \\
\hline$R$ rhipicephali ${ }^{12}$ & - & - & - & - & - & - & - & - & - & - & - & 1,000 & 0,982 & 0,988 & 0,931 & 0,971 \\
\hline R rickettsii ${ }^{13}$ & - & - & - & - & - & - & - & - & - & - & - & - & 1,000 & 0,988 & 0,925 & 0,971 \\
\hline$R$ sibirica $^{14}$ & - & - & - & - & - & - & - & - & - & - & - & - & - & 1,000 & 0,931 & 0,977 \\
\hline R. typhi $i^{15}$ & - & - & - & - & - & - & - & - & - & - & - & - & - & - & 1,000 & 0,922 \\
\hline$R \mathrm{sp} \mathrm{A} 6$ & - & - & - & - & - & - & - & - & - & - & - & - & - & - & - & 1,000 \\
\hline
\end{tabular}

\subsection{PESQUISA DE RIQUÉTSIAS EM POTENCIAIS HOSPEDEIROS}

\subsubsection{Imunofluorescência Indireta}

\subsubsection{Gambás}

Detectou-se a presença de anticorpos anti-R. rickettsii em 56 (59,6\%), anti- $R$. parkeri em 55 (58,5\%), anti-R. felis em 33 (35,1\%) e anti-R. bellii em 15 (15,9\%) gambás (Tabela 11).

Não houve associação entre a freqüência de gambás reagentes aos antígenos, das áreas endêmicas e não endêmicas ( $p>0,05)$. 
Tabela 14 - Presença de anticorpos anti-Rickettsia spp em gambás do Estado de São Paulo, através da reação de imunofluorescência indireta

\begin{tabular}{lllll}
\hline Gambás & Rickettsia rickettsii & Rickettsia parkeri & Rickettsia felis & Rickettsia bellii \\
\hline Pedreira & $11 / 14(78,6 \%)$ & $10 / 14(71,4 \%)$ & $9 / 14(64,3 \%)$ & $2 / 14(14,3 \%)$ \\
Mogi das Cruzes & $10 / 16(62,5 \%)$ & $8 / 16(50,0 \%)$ & $3 / 16(18,7 \%)$ & $0 / 16(0,0 \%)$ \\
Piracicaba & $11 / 17(64,7 \%)$ & $12 / 17(70,6 \%)$ & $11 / 17(64,7 \%)$ & $6 / 17(35,3 \%)$ \\
São Paulo & $18 / 35(51,4 \%)$ & $19 / 35(54,3 \%)$ & $6 / 35(17,1 \%)$ & $6 / 35(17,1 \%)$ \\
Pirassununga & $6 / 12(50,0 \%)$ & $6 / 12(50,0 \%)$ & $4 / 12(33,3 \%)$ & $1 / 12(8,3 \%)$ \\
\hline Total & $\mathbf{5 6 / 9 4}(\mathbf{5 9 , 6 )}$ & $\mathbf{5 5 / 9 4}(\mathbf{5 8 , 5 \% )}$ & $\mathbf{3 3 / 9 4}(\mathbf{3 5}, \mathbf{1 \% )}$ & $\mathbf{1 5 / 9 4}(\mathbf{1 5 , 9} \%)$
\end{tabular}

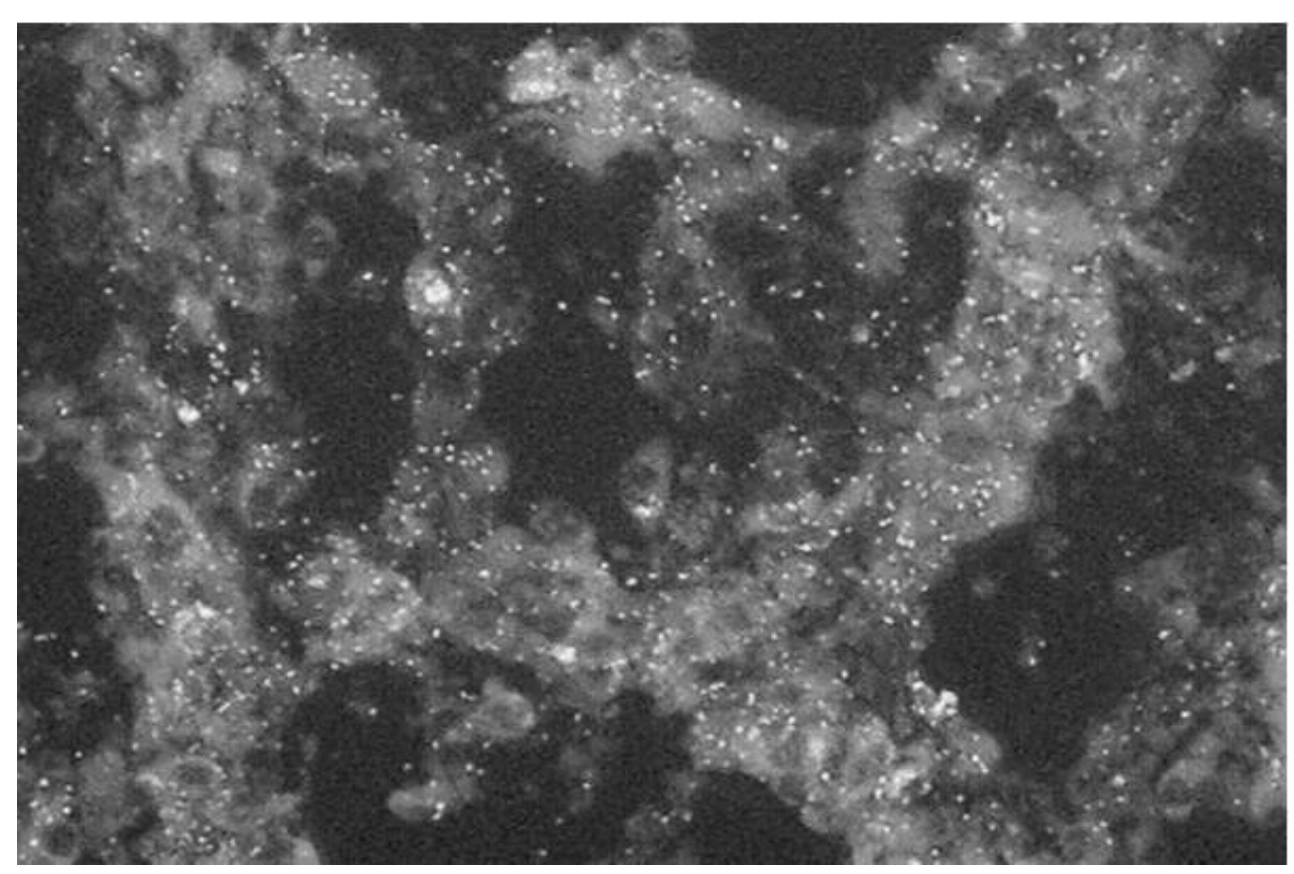

Figura 4 - Soro de gambá reagente ao antígeno de $R$. felis na reação de imunofluorescência indireta

\subsubsection{Cães}

Detectou-se a presença de anticorpos anti-R. rickettsii e anti-R. parkeri em 27 (49,1\%), anti-R. felis em $26(47,3 \%)$ e anti-R. bellii em $13(23,6 \%)$ cães (Tabela 12$)$. Não houve associação entre a freqüência de cães reagentes aos antígenos, das áreas endêmicas (grupo 1) e não endêmicas (grupo 2) ( $p>0,05)$. 
Tabela 15 - Presença de anticorpos anti-Rickettsia spp em cães do Estado de São Paulo, através da reação de imunofluorescência indireta

\begin{tabular}{lllll}
\hline Cães & Rickettsia rickettsii & Rickettsia parkeri & Rickettsia felis & Rickettsia bellii \\
\hline Pedreira & $11 / 19(57,9 \%)$ & $12 / 19(63,1 \%)$ & $13 / 19(68,4 \%)$ & $7 / 19(36,8 \%)$ \\
Mogi das Cruzes & $9 / 13(69,2 \%)$ & $9 / 13(69,2 \%)$ & $8 / 13(61,5 \%)$ & $5 / 13(38,5 \%)$ \\
Piracicaba & $3 / 7(42,8 \%)$ & $3 / 7(42,8 \%)$ & $2 / 7(28,6 \%)$ & $1 / 7(14,3 \%)$ \\
São Paulo & $3 / 11(27,3 \%)$ & $3 / 11(27,3 \%)$ & $3 / 11(27,3 \%)$ & $0 / 11(0,0 \%)$ \\
Pirassununga & $1 / 5(20,0 \%)$ & $0 / 5(0,0 \%)$ & $0 / 5(0,0 \%)$ & $0 / 5(0,0 \%)$ \\
\hline Total & $\mathbf{2 7 / 5 5 ( 4 9 , 1 \% )}$ & $\mathbf{2 7 / 5 5 ( 4 9 , 1 \% )}$ & $\mathbf{2 6 / 5 5 ( 4 7 , 3 \% )}$ & $\mathbf{1 3 / 5 5 ( 2 3 , 6 \% )}$
\end{tabular}

\subsubsection{Gatos}

Detectou-se a presença de anticorpos anti-R. rickettsii, anti-R. parkeri em 19 (76,0\%); anti -R. felis em $16(64,0 \%)$ e anti-R. bellii em 11 (44,0\%) gatos (Tabela 13). Não houve associação entre a freqüência de gatos reagentes aos antígenos, das áreas endêmicas (grupo 1) e não endêmicas (grupo 2) ( $p>0,05)$.

Tabela 16 - Presença de anticorpos anti-Rickettsia spp em gatos do Estado de São Paulo, através da reação de imunofluorescência indireta

\begin{tabular}{lllll}
\hline Gatos & Rickettsia rickettsii & Rickettsia parkeri & Rickettsia felis & Rickettsia bellii \\
\hline Pedreira & $3 / 3(100,0 \%)$ & $3 / 3(100,0 \%)$ & $3 / 3(100,0 \%)$ & $2 / 3(66.7 \%)$ \\
Mogi das Cruzes & $3 / 3(100,0 \%)$ & $3 / 3(100,0 \%)$ & $3 / 3(100,0 \%)$ & $2 / 3(66,7)$ \\
Piracicaba & $7 / 7(100,0)$ & $6 / 7(85,7 \%)$ & $6 / 7(85,7 \%)$ & $4 / 7(57,1 \%)$ \\
São Paulo & $3 / 6(50,0 \%)$ & $3 / 6(50,0 \%)$ & $2 / 6(33,3 \%)$ & $0 / 6(0,0 \%)$ \\
Pirassununga & $3 / 6(50,0 \%)$ & $4 / 6(66,7 \%)$ & $2 / 6(33,3 \%)$ & $3 / 6(50,0 \%)$ \\
\hline Total & $\mathbf{1 9 / 2 5}(\mathbf{7 6 , 0} \%)$ & $\mathbf{1 9 / 2 5} \mathbf{( 7 6 , 0 \% )}$ & $\mathbf{1 6 / 2 5 ( 6 4 , 0 \% )}$ & $\mathbf{1 1 / 2 5 ( 4 4 , 0 \% )}$ \\
\hline
\end{tabular}

\subsubsection{Eqüinos}

Detectou-se a presença de anticorpos anti- $R$. rickettsii e anti-R. parkeri em 48 (56,5\%), anti-R. felis em $47(55,3 \%)$ e anti-R. bellii em 62 (72,9\%) eqüinos (Tabela 14). À análise estatística, houve associação entre a freqüência de eqüinos reagentes aos diferentes antígenos, das áreas endêmicas (grupo 1) e não endêmicas (grupo 2) $(p<0,05)$. 
Tabela 17 - Presença de anticorpos anti-Rickettsia spp em eqüinos do Estado de São Paulo, através da reação de imunofluorescência indireta

\begin{tabular}{lllll}
\hline Eqüinos & Rickettsia rickettsii & Rickettsia parkeri & Rickettsia felis & Rickettsia bellii \\
\hline Pedreira & $18 / 20(90,0 \%)$ & $18 / 20(90,0 \%)$ & $19 / 20(95,0 \%)$ & $19 / 20(95,0 \%)$ \\
Mogi das Cruzes & $2 / 5(40,0 \%)$ & $2 / 5(40,0 \%)$ & $2 / 5(40,0 \%)$ & $3 / 5(60,0 \%)$ \\
Piracicaba & $17 / 21(80,9 \%)$ & $17 / 21(80,9 \%)$ & $17 / 21(80,9 \%)$ & $19 / 21(90,5 \%)$ \\
São Paulo & $7 / 20(35,0 \%)$ & $7 / 20(35,0 \%)$ & $5 / 20(35,0 \%)$ & $11 / 20(55,0 \%)$ \\
Pirassununga & $4 / 19(21,0 \%)$ & $4 / 19(21,0 \%)$ & $4 / 19(21,0 \%)$ & $10 / 19(52,6 \%)$ \\
\hline Total & $\mathbf{4 8 / 8 5 ( 5 6 , 5 \% )}$ & $\mathbf{4 8 / 8 5 ( 5 6 , 5 \% )}$ & $\mathbf{4 7 / 8 5 ( 5 5 , 3 \% )}$ & $\mathbf{6 2 / 8 5}(\mathbf{7 2 , 9 \% )}$ \\
\hline
\end{tabular}

\subsubsection{Humanos}

Detectou-se a presença de anticorpos anti-R. rickettsii em 34 (14,3\%), anti- $R$. parkeri em $32(13,4 \%)$, anti-R. felis em $28(11,8 \%)$ e anti-R. bellii em $23(9,7 \%)$ humanos (Tabela 15). Não houve associação entre a freqüência de humanos reagentes aos antígenos, das áreas endêmicas e não endêmicas ( $p>0,05)$.

Tabela 18 - Presença de anticorpos anti-Rickettsia spp em humanos do Estado de São Paulo, através da reação de imunofluorescência indireta

\begin{tabular}{lllll}
\hline Humanos & Rickettsia rickettsii & Rickettsia parkeri & Rickettsia felis & Rickettsia bellii \\
\hline Pedreira & $8 / 52(15,4 \%)$ & $8 / 52(15,4 \%)$ & $8 / 52(15,4 \%)$ & $5 / 52(9,6 \%)$ \\
Mogi das Cruzes & $4 / 21(19,0 \%)$ & $4 / 21(19,0 \%)$ & $4 / 21(19,0 \%)$ & $4 / 21(19,0 \%)$ \\
Piracicaba & $7 / 69(10,1 \%)$ & $5 / 69(7,2 \%)$ & $5 / 69(7,2 \%)$ & $6 / 69(8,7 \%)$ \\
São Paulo & $10 / 68(14,7 \%)$ & $10 / 68(14,7 \%)$ & $6 / 68(8,8 \%)$ & $5 / 68(7,3 \%)$ \\
Pirassununga & $5 / 28(17,8 \%)$ & $5 / 28(17,8 \%)$ & $5 / 28(17,8 \%)$ & $3 / 28(10,7 \%)$ \\
\hline Total & $\mathbf{3 4 / 2 3 8 ( 1 4 , 3 \% )}$ & $\mathbf{3 2 / 2 3 8 ( 1 3 , 4 \% )}$ & $\mathbf{2 8 / 2 3 8 ( 1 1 , 8 \% )}$ & $\mathbf{2 3 / 2 3 8 ~ ( 9 , 7 \% )}$ \\
\hline
\end{tabular}

4.5.1.5 Análise dos títulos de anticorpos

As titulações obtidas nos soros dos hospedeiros e gambás, cães, gatos, eqüinos e humanos frente aos antígenos testados, estão relacionados nos apêndices de $A$ a $E$. 
Os anticorpos de um hospedeiro foram considerados homólogos a uma dada espécie de Rickettsia quando o título apresentado para esta foi pelo menos quatro vezes maior que o título mais alto obtido para as demais espécies, conforme interpretações previamente padronizadas (HORTA et al., 2004). Sob este critério, determinou-se como antígeno provável responsável pela infecção natural nos hospedeiros examinados: $R$. rickettsii (em 10 gambás, 4 cães, 1 eqüino e 2 humanos) e $R$. parkeri (3 gambás, 1 cão e 1 eqüino). A tabela 16 reúne os dados dos hospedeiros que apresentaram títulos nestas condições. Os dados sobre os títulos obtidos para cada um dos hospedeiros encontram-se nos apêndices F a J.

Tabela 19 - Títulos de anticorpos anti-Rickettsia spp através da reação de imunofluorescência indireta (RIFI), em gambás, cães, eqüinos e humanos, de cinco áreas do estado de São Paulo para quatro espécies de Rickettsia

\begin{tabular}{|c|c|c|c|c|c|c|}
\hline \multirow[t]{2}{*}{ Soro* } & \multirow[t]{2}{*}{ Município } & \multicolumn{4}{|c|}{ Títulos RIFI para os seguintes antígenos } & \multirow{2}{*}{$\begin{array}{l}\text { Antígeno } \\
\text { Provável* }\end{array}$} \\
\hline & & R. rickettsii & R. parkeri & R. felis & R. bellii & \\
\hline Gambá29 & Piracicaba & 512 & 128 & 64 & NR & R. rickettsii \\
\hline Gambá30 & Piracicaba & 32.768 & 4.096 & 2.048 & 4.096 & R. rickettsii \\
\hline Gambá33 & Piracicaba & 4.096 & 512 & 512 & 1.024 & R. rickettsii \\
\hline Gambá36 & São Paulo & 1.024 & 256 & 256 & NR & R. rickettsii \\
\hline Gambá49 & Pedreira & 2.048 & 256 & 128 & NR & R. rickettsii \\
\hline Gambá55 & Piracicaba & 512 & 128 & 128 & 128 & R. rickettsii \\
\hline Gambá56 & Mogi das Cruzes & 2.048 & 256 & 512 & NR & R. rickettsii \\
\hline Gambá70 & Mogi das Cruzes & 256 & 64 & NR & NR & R. rickettsii \\
\hline Gambá93 & Pedreira & 2.048 & 512 & 64 & NR & R. rickettsii \\
\hline Gambá96 & Pedreira & 512 & 64 & 128 & NR & R. rickettsii \\
\hline Gambá46 & Pirassununga & 256 & 1.024 & 256 & NR & R. parkeri \\
\hline Gambá68 & Pedreira & 64 & 256 & 64 & NR & R. parkeri \\
\hline Gambá71 & Mogi das Cruzes & 64 & 256 & NR & NR & R. parkeri \\
\hline Cão27 & Pedreira & 4096 & 1024 & 1024 & 128 & R. rickettsii \\
\hline Cão29 & Pedreira & 2048 & 512 & 256 & 64 & R. rickettsii \\
\hline Cão33 & Mogi das Cruzes & 256 & 64 & 64 & NR & R. rickettsii \\
\hline Cão36 & Mogi das Cruzes & 2048 & 512 & NR & NR & R. rickettsii \\
\hline Cão51 & Piracicaba & 64 & 256 & NR & NR & R. parkeri \\
\hline Eqüino & Piracicaba & 1024 & 256 & 128 & 256 & R. rickettsii \\
\hline Eqüino & Piracicaba & 1024 & 4096 & 512 & 512 & R. parkeri \\
\hline Humano75 & Pedreira & 256 & 64 & 64 & NR & R. rickettsii \\
\hline Humano29 & Piracicaba & 512 & 128 & 64 & 128 & R. rickettsii \\
\hline
\end{tabular}




\subsubsection{Reação em Cadeia pela Polimerase (PCR)}

As amostras de sangue colhidas de gambás (94), cães (55), gatos (25), eqüinos (85) e humanos (238) foram testadas na PCR para o gene gltA, utilizandose os pares de "primers" CS3-922/CS3-1068. Não houve amplificação do DNA genômico em nenhuma das amostras.

\subsection{CULTIVO CELULAR}

\subsubsection{Isolamento de Rickettsia felis}

Alíquotas de dez pools constituídos de cinco pulgas cada um, provenientes de Pedreira/SP, foram utilizadas para realização do isolamento de $R$. felis. Cinco alíquotas foram inoculadas em "shell vials" contendo células C6/36 e outras cinco em "shell vials" contendo células VERO e, a seguir, incubadas a $28^{\circ} \mathrm{C}$.

No terceiro dia pós-infecção, realizou-se a troca de meio com antibiótico por um meio sem. No quinto dia, o meio de cultivo foi retirado e corado com fucsina e verde malaquita (GIMENEZ, 1964), quando se visualizou a presença de estruturas semelhantes a Rickettsia infectando os dois tipos celulares, numa porcentagem de infecção de aproximadamente $1 \%$. Em outra alíquota do meio, submetida à PCR e sequenciamento de DNA, confirmou-se a presença de $R$. felis.

A seguir, as monocamadas contidas nos "shell vials" foram transferidas para garrafas de $25 \mathrm{~cm}^{3}$. Trocas a cada 4-5 dias foram necessárias para manutenção e acompanhamento da evolução da taxa de infecção das células. 
A infecção na linhagem de células VERO foi gradativamente diminuindo, até sua total eliminação ao final de 30 dias. No $40^{\circ}$ dia, a linhagem de células $C 6 / 36$, mantida até então a $28^{\circ} \mathrm{C}$, foi incubada a $25^{\circ} \mathrm{C}$. Após 20 dias de incubação nessa nova temperatura, verificou-se um aumento da taxa de infecção, chegando a $90 \%$ de células infectadas. Nesse momento, as células infectadas foram transferidas para uma garrafa de $75 \mathrm{~cm}^{3}$ e após aproximadamente 20 dias atingiram $\cong 100 \%$ de infecção.

Este procedimento possibilitou sucessivas infecções para manutenção da cepa isolada. Os isolados foram preservados a $-80^{\circ} \mathrm{C}$. A cepa isolada de Rickettsia felis, denominada cepa PEDREIRA, foi confirmada depois de realização de PCR e sequenciamento de DNA (HORTA et al., 2006).

Os fragmentos de DNA analisados do gene gltA da cepa PEDREIRA apresentaram $100 \%$ de identidade $(1.080 / 1.080 \mathrm{pb})$ com $R$. felis cepa URRWXCal2 (Califórnia/EUA - AF210692 e CP000053.1) (OGATA et al., 2005), 97,8\% (1.045/1.068) à R. felis cepa RF2125 (Tailândia - AF516333.1) (PAROLA et al., 2003) e 97,4\% (1.052/1.080) à Rickettsia felis-like (Croácia - DQ081187.1) (DUH et al., 2005). A identidade obtida entre a cepa PEDREIRA e outras riquétsias disponibilizadas no GenBank podem ser visualizadas nas tabelas 20, 21 e 22.

\subsubsection{Isolamento de Rickettsia bellii}

Um carrapato adulto Ixodes loricatus, fêmea, proveniente de Mogi das Cruzes/SP, foi utilizado para realização do isolamento de $R$. bellii. Seis alíquotas foram inoculadas em "shell vials" contendo células C6/36 e outras seis foram inoculadas em "shell vials" contendo células VERO. Após o procedimento, o material 
foi incubado a $28^{\circ} \mathrm{C}$. O meio de meio de cultivo foi retirado semanalmente, e corado com fucsina e verde malaquita (GIMENEZ, 1964). A presença de estruturas semelhantes a Rickettsia foi visualizada nas duas linhagens celulares. Nas garrafas infectadas com células VERO, as riquétsias apresentaram sua forma característica (bastonetes filamentosos compridos) 90 pós-infecção. A cepa de Rickettsia bellii foi confirmada depois de realização de extração, PCR e sequenciamento de DNA do material isolado, e foi denominada Rickettsia bellii cepa IXODES (HORTA et al., 2005e). A identidade obtida entre esta cepa e outras riquétsias disponibilizadas no GenBank (genes gltA e 17kDa) podem ser visualizadas nas tabelas 23 e 24 .

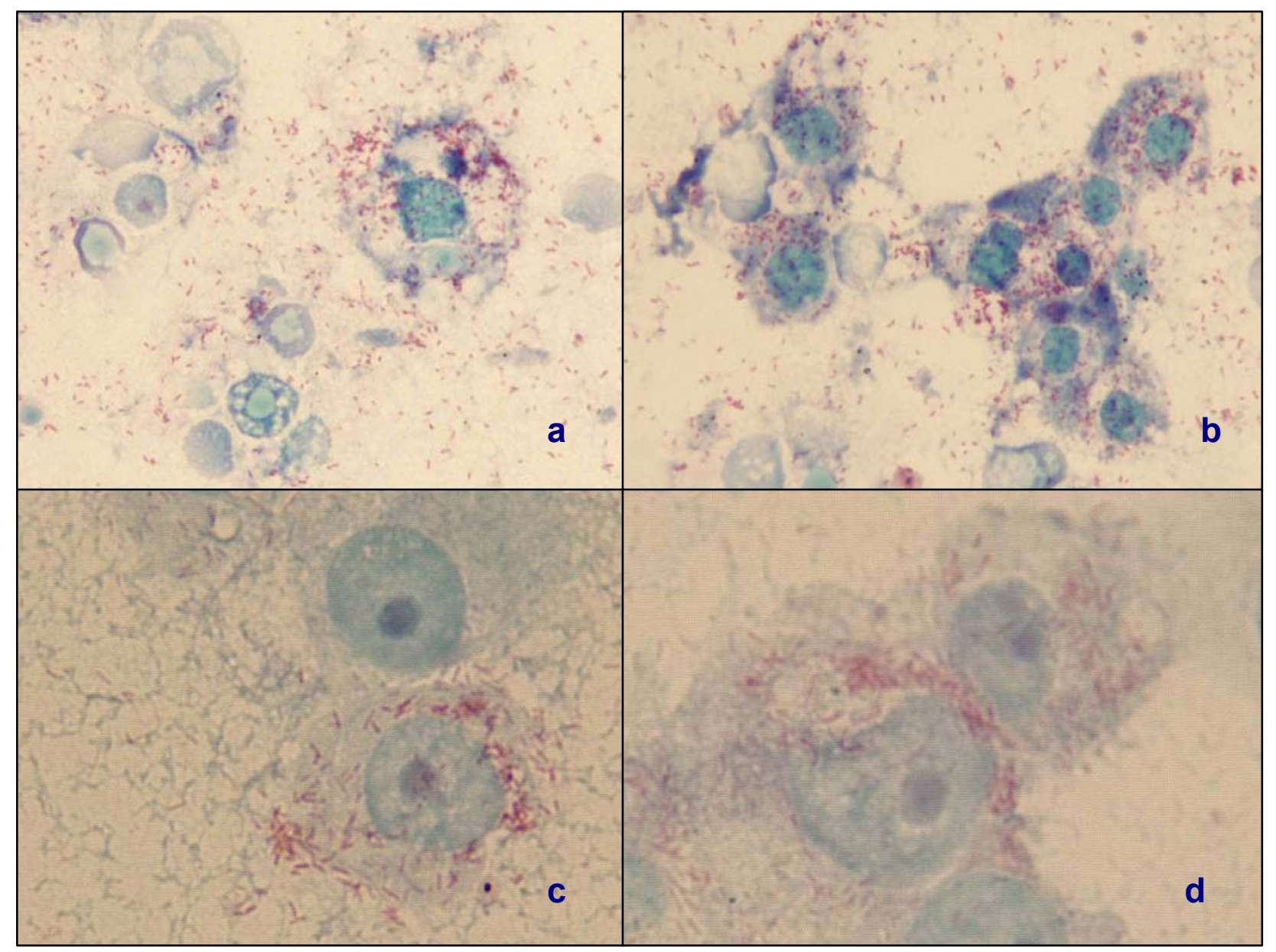

Figura 5 - (a), (b) células C6/36 infectadas com Rickettsia felis cepa PEDREIRA, coradas com fucsina e verde malaquita; (c), (d) células VERO infectadas com $R$. bellii cepa IXODES, coradas com fucsina e verde malaquita 
Tabela 20 - Grau de identidade calculado para cada par de seqüências de nucleotídeos, entre Rickettsia felis cepa PEDREIRA isolada de pulgas Ctenocephalides felis felis de cães, através do sequenciamento de DNA (gene glttA, 1.070pb) e seqüências de Rickettsia spp do GenBank. 2006

\begin{tabular}{|c|c|c|c|c|c|c|c|c|c|c|c|c|c|c|c|c|c|c|c|c|c|}
\hline & $\begin{array}{c}R \\
\text { aes }\end{array}$ & $\begin{array}{l}R \\
\text { afr }\end{array}$ & $\begin{array}{c}R \\
\text { aka }\end{array}$ & $\begin{array}{c}R \\
a m b\end{array}$ & $\begin{array}{c}R \\
\text { aus }\end{array}$ & $\begin{array}{c}R \\
b e l\end{array}$ & $\begin{array}{c}R \\
\text { can }\end{array}$ & $\begin{array}{c}R \\
\text { con }\end{array}$ & $\begin{array}{c}R \\
f e l^{9}\end{array}$ & $\begin{array}{c}R \\
\mathrm{fel}^{10}\end{array}$ & $\begin{array}{c}R \\
f e l^{11}\end{array}$ & $\begin{array}{c}R \\
f e l^{12}\end{array}$ & $\begin{array}{c}R \\
\text { hon }\end{array}$ & $\begin{array}{c}R \\
\text { jap }\end{array}$ & $\begin{array}{c}R \\
\text { par }\end{array}$ & $\begin{array}{c}R \\
\text { pro }\end{array}$ & $\begin{array}{c}R \\
r h i\end{array}$ & $\begin{array}{l}R \\
\text { ric }\end{array}$ & $\begin{array}{l}R \\
s i b\end{array}$ & $\begin{array}{c}R \\
\text { typ }\end{array}$ & $\begin{array}{c}R \\
f e l P\end{array}$ \\
\hline R. aeschlimannii ${ }^{1}$ & 1,000 & 0,987 & 0,937 & 0,985 & 0,946 & 0,866 & 0,911 & 0,988 & 0,94 & 0,943 & 0,937 & 0,940 & 0,988 & 0,985 & 0,991 & 0,928 & 0,989 & 0,982 & 0,992 & 0,926 & 0,940 \\
\hline R. africae $e^{2}$ & - & 1,000 & 0,938 & 0,983 & 0,946 & 0,864 & 0,910 & 0,991 & 0,939 & 0,938 & 0,935 & 0,936 & 0,992 & 0,988 & 0,994 & 0,929 & 0,985 & 0,985 & 0,995 & 0,925 & 0,939 \\
\hline R. akari $^{3}$ & - & - & 1,000 & 0,935 & 0,970 & 0,854 & 0,891 & 0,939 & 0,946 & 0,942 & 0,940 & 0,940 & 0,938 & 0,934 & 0,938 & 0,909 & 0,939 & 0,933 & 0,939 & 0,910 & 0,946 \\
\hline R. amblyommi ${ }^{4}$ & - & - & - & 1,000 & 0,943 & 0,862 & 0,913 & 0,985 & 0,938 & 0,939 & 0,934 & 0,933 & 0,985 & 0,983 & 0,985 & 0,925 & 0,984 & 0,978 & 0,986 & 0,925 & 0,938 \\
\hline R. australis ${ }^{5}$ & - & - & - & - & 1,000 & 0,856 & 0,894 & 0,945 & 0,952 & 0,946 & 0,943 & 0,945 & 0,946 & 0,942 & 0,946 & 0,910 & 0,946 & 0,939 & 0,947 & 0,910 & 0,952 \\
\hline R. bellii ${ }^{6}$ & - & - & - & - & - & 1,000 & 0,854 & 0,864 & 0,857 & 0,864 & 0,865 & 0,864 & 0,863 & 0,862 & 0,867 & 0,852 & 0,862 & 0,861 & 0,866 & 0,857 & 0,857 \\
\hline R. canadensis $^{7}$ & - & - & - & - & - & - & 1,000 & 0,913 & 0,907 & 0,905 & 0,898 & 0,902 & 0,912 & 0,911 & 0,913 & 0,891 & 0,910 & 0,908 & 0,913 & 0,896 & 0,907 \\
\hline R. conorii $^{8}$ & - & - & - & - & - & - & - & 1,000 & 0,940 & 0,939 & 0,936 & 0,935 & 0,994 & 0,989 & 0,995 & 0,929 & 0,987 & 0,989 & 0,996 & 0,929 & 0,940 \\
\hline R. felis calif $\mathrm{USA}^{9}$ & - & - & - & - & - & - & - & - & 1,000 & 0,978 & 0,973 & 0,973 & 0,940 & 0,937 & 0,940 & 0,904 & 0,942 & 0,934 & 0,941 & 0,901 & 1,000 \\
\hline R. felis $2125 \mathrm{TAI}^{10}$ & - & - & - & - & - & - & - & - & - & 1,000 & 0,976 & 0,978 & 0,940 & 0,936 & 0,940 & 0,905 & 0,941 & 0,934 & 0,940 & 0,902 & 0,978 \\
\hline R. felis Hs $\mathrm{CRO}^{11}$ & - & - & - & - & - & - & - & - & - & - & 1,000 & 0,973 & 0,936 & 0,933 & 0,937 & 0,905 & 0,939 & 0,932 & 0,938 & 0,902 & 0,973 \\
\hline R. felis $31 \mathrm{TAI}^{12}$ & - & - & - & - & - & - & - & - & - & - & - & 1,000 & 0,935 & 0,932 & 0,936 & 0,905 & 0,938 & 0,933 & 0,937 & 0,903 & 0,973 \\
\hline R. honei $i^{13}$ & - & - & - & - & - & - & - & - & - & - & - & - & 1,000 & 0,989 & 0,995 & 0,927 & 0,987 & 0,987 & 0,996 & 0,925 & 0,940 \\
\hline R. japonica ${ }^{14}$ & - & - & - & - & - & - & - & - & - & - & - & - & - & 1,000 & 0,990 & 0,926 & 0,985 & 0,983 & 0,991 & 0,926 & 0,937 \\
\hline R. parkeri $^{15}$ & - & - & - & - & - & - & - & - & - & - & - & - & - & - & 1,000 & 0,929 & 0,988 & 0,988 & 0,999 & 0,927 & 0,940 \\
\hline R. prowazekii ${ }^{16}$ & - & - & - & - & - & - & - & - & - & - & - & - & - & - & - & 1,000 & 0,927 & 0,922 & 0,929 & 0,966 & 0,904 \\
\hline R. rhipicephali ${ }^{17}$ & - & - & - & - & - & - & - & - & - & - & - & - & - & - & - & - & 1,000 & 0,981 & 0,989 & 0,925 & 0,942 \\
\hline R. rickettsii ${ }^{18}$ & - & - & - & - & - & - & - & - & - & - & - & - & - & - & - & - & - & 1,000 & 0,989 & 0,922 & 0,934 \\
\hline R. sibirica ${ }^{19}$ & - & - & - & - & - & - & - & - & - & - & - & - & - & - & - & - & - & - & 1,000 & 0,927 & 0,941 \\
\hline R. typhi $i^{20}$ & - & - & - & - & - & - & - & - & - & - & - & - & - & - & - & - & - & - & - & 1,000 & 0,901 \\
\hline R. felis PEDREIRA & - & - & - & - & - & - & - & - & - & - & - & - & - & - & - & - & - & - & - & - & 1,000 \\
\hline
\end{tabular}


Tabela 21 - Grau de identidade calculado para cada par de seqüências de nucleotídeos, entre Rickettsia felis cepa PEDREIRA isolada de pulgas Ctenocephalides felis felis de cães, através do sequenciamento de DNA (gene 17kDa, 376 pb) e seqüências de Rickettsia spp do GenBank. 2006

\begin{tabular}{|c|c|c|c|c|c|c|c|c|c|c|c|c|c|c|c|c|c|c|c|c|c|}
\hline & $\begin{array}{c}R \\
\text { aka }\end{array}$ & $\begin{array}{c}R \\
a m b\end{array}$ & $\begin{array}{c}R \\
\text { aus }\end{array}$ & $\begin{array}{c}R \\
b e l\end{array}$ & $\begin{array}{c}R \\
\text { can }\end{array}$ & $\begin{array}{c}R \\
\text { con }\end{array}$ & $\begin{array}{c}R \\
\mathrm{fel}^{7}\end{array}$ & $\begin{array}{c}R \\
\mathrm{fe}^{8}\end{array}$ & $\begin{array}{c}R \\
\mathrm{fe}^{9}\end{array}$ & $\begin{array}{c}R \\
\mathrm{fel}^{10}\end{array}$ & $\begin{array}{c}R \\
\mathrm{fel}^{11}\end{array}$ & $\begin{array}{c}R \\
f e l^{12} \\
\end{array}$ & $\begin{array}{c}R \\
\mathrm{fel}^{13}\end{array}$ & $\begin{array}{c}R \\
\text { hon }\end{array}$ & $\begin{array}{c}R \\
\text { par }\end{array}$ & $\begin{array}{c}R \\
\text { pro }\end{array}$ & $\begin{array}{c}R \\
r h i\end{array}$ & $\begin{array}{l}R \\
\text { ric } \\
\end{array}$ & $\begin{array}{c}R \\
\text { sib } \\
\end{array}$ & $\begin{array}{c}R \\
\text { typ }\end{array}$ & $\begin{array}{c}R \\
f e / P\end{array}$ \\
\hline R. akari ${ }^{1}$ & 1,000 & 0,944 & 0,970 & 0,781 & 0,845 & 0,949 & 0,936 & 0,936 & 0,936 & 0,936 & 0,936 & 0,928 & 0,952 & 0,954 & 0,952 & 0,875 & 0,952 & 0,952 & 0,949 & 0,880 & 0,936 \\
\hline R. amblyommii ${ }^{2}$ & - & 1,000 & 0,962 & 0,784 & 0,845 & 0,978 & 0,936 & 0,936 & 0,936 & 0,936 & 0,936 & 0,928 & 0,952 & 0,984 & 0,981 & 0,877 & 0,976 & 0,981 & 0,978 & 0,880 & 0,936 \\
\hline R. australis ${ }^{3}$ & - & - & 1,000 & 0,787 & 0,859 & 0,962 & 0,952 & 0,952 & 0,952 & 0,952 & 0,952 & 0,949 & 0,968 & 0,968 & 0,965 & 0,882 & 0,965 & 0,965 & 0,962 & 0,888 & 0,952 \\
\hline R. bellii ${ }^{4}$ & - & - & - & 1,000 & 0,816 & 0,800 & 0,781 & 0,781 & 0,781 & 0,781 & 0,781 & 0,776 & 0,797 & 0,795 & 0,797 & 0,776 & 0,797 & 0,797 & 0,795 & 0,779 & 0,781 \\
\hline R. canadensis $^{5}$ & - & - & - & - & 1,000 & 0,851 & 0,864 & 0,864 & 0,864 & 0,864 & 0,864 & 0,848 & 0,859 & 0,856 & 0,853 & 0,808 & 0,859 & 0,853 & 0,856 & 0,797 & 0,864 \\
\hline$R$. conorii ${ }^{6}$ & - & - & - & - & - & 1,000 & 0,936 & 0,936 & 0,936 & 0,936 & 0,936 & 0,928 & 0,957 & 0,994 & 0,997 & 0,877 & 0,981 & 0,997 & 0,994 & 0,880 & 0,936 \\
\hline R. felis calif $\mathrm{EUA}^{7}$ & - & - & - & - & - & - & 1,000 & 1,000 & 1,000 & 1,000 & 1,000 & 0,976 & 0,962 & 0,941 & 0,938 & 0,880 & 0,938 & 0,938 & 0,941 & 0,880 & 1,000 \\
\hline R. felis $\mathrm{EUA}^{8}$ & - & - & - & - & - & - & - & 1,000 & 1,000 & 1,000 & 1,000 & 0,976 & 0,962 & 0,941 & 0,938 & 0,880 & 0,938 & 0,938 & 0,941 & 0,880 & 1,000 \\
\hline R. felis scc50 EUA 9 & - & - & - & - & - & - & - & - & 1,000 & 1,000 & 1,000 & 0,976 & 0,962 & 0,941 & 0,938 & 0,880 & 0,938 & 0,938 & 0,941 & 0,880 & 1,000 \\
\hline R. felis Hf187 JAP ${ }^{10}$ & - & - & - & - & - & - & - & - & - & 1,000 & 1,000 & 0,976 & 0,962 & 0,941 & 0,938 & 0,880 & 0,938 & 0,938 & 0,941 & 0,880 & 1,000 \\
\hline R. felis TwKm03 $\mathrm{T}^{11}$ & - & - & - & - & - & - & - & - & - & - & 1,000 & 0,976 & 0,962 & 0,941 & 0,938 & 0,880 & 0,938 & 0,938 & 0,941 & 0,880 & 1,000 \\
\hline R. felis cf15 $\mathrm{EUA}^{12}$ & - & - & - & - & - & - & - & - & - & - & - & 1,000 & 0,954 & 0,933 & 0,930 & 0,877 & 0,930 & 0,93 & 0,928 & 0,877 & 0,976 \\
\hline R. felis c 1 e $5 \mathrm{EUA}^{13}$ & - & - & - & - & - & - & - & - & - & - & - & - & 1,000 & 0,957 & 0,954 & 0,888 & 0,954 & 0,954 & 0,952 & 0,893 & 0,962 \\
\hline R. honei ${ }^{14}$ & - & - & - & - & - & - & - & - & - & - & - & - & - & 1,000 & 0,997 & 0,882 & 0,986 & 0,997 & 0,994 & 0,885 & 0,941 \\
\hline R. parkeri $^{15}$ & - & - & - & - & - & - & - & - & - & - & - & - & - & - & 1,000 & 0,880 & 0,984 & 1,000 & 0,997 & 0,882 & 0,938 \\
\hline R. prowazekii ${ }^{16}$ & - & - & - & - & - & - & - & - & - & - & - & - & - & - & - & 1,000 & 0,888 & 0,88 & 0,877 & 0,952 & 0,880 \\
\hline R. rhipicephali ${ }^{17}$ & - & - & - & - & - & - & - & - & - & - & - & - & - & - & - & - & 1,000 & 0,984 & 0,981 & 0,885 & 0,938 \\
\hline R. rickettsii ${ }^{18}$ & - & - & - & - & - & - & - & - & - & - & - & - & - & - & - & - & - & 1,000 & 0,997 & 0,882 & 0,938 \\
\hline R. sibirica ${ }^{19}$ & - & - & - & - & - & - & - & - & - & - & - & - & - & - & - & - & - & - & 1,000 & 0,88 & 0,941 \\
\hline R. typhi $i^{20}$ & - & - & - & - & - & - & - & - & - & - & - & - & - & - & - & - & - & - & - & 1,000 & 0,88 \\
\hline
\end{tabular}

R. felis PEDREIRA

GenBank: ${ }^{1} \mathrm{AF} 445383.1,{ }^{2} \mathrm{U} 11013.1,{ }^{3} \mathrm{M} 74042.1,{ }^{4} \mathrm{AF} 445380.1,{ }^{5} \mathrm{AF} 445381.1,{ }^{6} \mathrm{M} 28480.1,{ }^{7} \mathrm{AF} 210693.1,{ }^{8} \mathrm{AF} 195118.1,{ }^{9} \mathrm{DQ} 102709.1$ ${ }^{10} \mathrm{AB} 114813.1,{ }^{11} \mathrm{~A} Y 445822.1,{ }^{12} \mathrm{~A} Y 953285.1,{ }^{13} \mathrm{~A} Y 953286.1,{ }^{14} \mathrm{AF} 060704.1,{ }^{15} \mathrm{U} 17008.1,{ }^{16} \mathrm{~A} Y 570301.1,{ }^{17} \mathrm{U} 11020.1,{ }^{18} \mathrm{~A} Y 281069.1$, ${ }^{19} \mathrm{AF} 445384.1,{ }^{20} \mathrm{M} 28481.1$ 
Tabela 22 - Grau de identidade calculado para cada par de seqüências de nucleotídeos, entre Rickettsia felis cepa PEDREIRA isolada de pulgas Ctenocephalides felis felis de cães, através do sequenciamento de DNA (gene OmpB, 703 pb) e seqüências de Rickettsia spp do GenBank. 2006

\begin{tabular}{|c|c|c|c|c|c|c|c|c|c|c|c|c|c|c|c|c|c|c|}
\hline & $\begin{array}{c}R \\
\text { aes }\end{array}$ & $\begin{array}{l}R \\
\text { afr }\end{array}$ & $\begin{array}{c}R \\
\text { aka }\end{array}$ & $\begin{array}{c}R \\
a m b\end{array}$ & $\begin{array}{c}R \\
\text { aus }\end{array}$ & $\begin{array}{c}R \\
\text { con } \\
\end{array}$ & $\begin{array}{c}R \\
\mathrm{fel}^{7}\end{array}$ & $\begin{array}{c}R \\
f e l^{8}\end{array}$ & $\begin{array}{c}R \\
f e l^{9}\end{array}$ & $\begin{array}{c}R \\
f e l^{10}\end{array}$ & $\begin{array}{c}R \\
\text { hon }\end{array}$ & $\begin{array}{c}R \\
\text { jap }\end{array}$ & $\begin{array}{c}R \\
m o n\end{array}$ & $\begin{array}{c}R \\
\text { par }\end{array}$ & $\begin{array}{c}R \\
r h i\end{array}$ & $\begin{array}{l}R \\
\text { ric } \\
\end{array}$ & $\begin{array}{l}R \\
\text { sib } \\
\end{array}$ & $\begin{array}{c}R \\
f e / P\end{array}$ \\
\hline R. aeschlimannii ${ }^{1}$ & 1,000 & 0,923 & 0,872 & 0,949 & 0,895 & 0,913 & 0,925 & 0,923 & 0,922 & 0,926 & 0,913 & 0,931 & 0,944 & 0,918 & 0,971 & 0,938 & 0,925 & 0,925 \\
\hline R. africae $e^{2}$ & - & 1,000 & 0,851 & 0,915 & 0,871 & 0,967 & 0,893 & 0,893 & 0,89 & 0,895 & 0,935 & 0,922 & 0,902 & 0,987 & 0,913 & 0,951 & 0,992 & 0,893 \\
\hline R. akari $^{3}$ & - & - & 1,000 & 0,867 & 0,924 & 0,844 & 0,898 & 0,897 & 0,897 & 0,900 & 0,850 & 0,864 & 0,871 & 0,847 & 0,870 & 0,858 & 0,852 & 0,898 \\
\hline R. amblyommi ${ }^{4}$ & - & - & - & 1,000 & 0,881 & 0,908 & 0,915 & 0,913 & 0,913 & 0,916 & 0,908 & 0,929 & 0,94 & 0,911 & 0,951 & 0,928 & 0,916 & 0,915 \\
\hline R. australis ${ }^{5}$ & - & - & - & - & 1,000 & 0,861 & 0,924 & 0,922 & 0,921 & 0,925 & 0,865 & 0,885 & 0,886 & 0,868 & 0,887 & 0,875 & 0,872 & 0,924 \\
\hline R. conorii $^{6}$ & - & - & - & - & - & 1,000 & 0,882 & 0,883 & 0,882 & 0,883 & 0,925 & 0,916 & 0,890 & 0,961 & 0,905 & 0,936 & 0,968 & 0,882 \\
\hline R. felis calif $\mathrm{EUA}^{7}$ & - & - & - & - & - & - & 1,000 & 0,998 & 0,994 & 0,998 & 0,885 & 0,903 & 0,917 & 0,888 & 0,921 & 0,899 & 0,895 & 1,000 \\
\hline R. felis $\mathrm{EUA}^{8}$ & - & - & - & - & - & - & - & 1,000 & 0,992 & 0,997 & 0,886 & 0,905 & 0,915 & 0,888 & 0,919 & 0,899 & 0,895 & 0,998 \\
\hline R. felis An $\mathrm{EUA}^{9}$ & - & - & - & - & - & - & - & - & 1,000 & 0,995 & 0,882 & 0,901 & 0,914 & 0,885 & 0,918 & 0,896 & 0,892 & 0,994 \\
\hline R. felis scc50 $\mathrm{EUA}^{10}$ & - & - & - & - & - & - & - & - & - & 1,000 & 0,886 & 0,905 & 0,918 & 0,889 & 0,922 & 0,901 & 0,896 & 0,998 \\
\hline R. honei $i^{11}$ & - & - & - & - & - & - & - & - & - & - & 1,000 & 0,912 & 0,891 & 0,932 & 0,912 & 0,945 & 0,934 & 0,885 \\
\hline R. japonica ${ }^{12}$ & - & - & - & - & - & - & - & - & - & - & - & 1,000 & 0,92 & 0,918 & 0,923 & 0,925 & 0,923 & 0,903 \\
\hline R. montanensis ${ }^{13}$ & - & - & - & - & - & - & - & - & - & - & - & - & 1,000 & 0,897 & 0,944 & 0,920 & 0,904 & 0,917 \\
\hline R. parkeri ${ }^{14}$ & - & - & - & - & - & - & - & - & - & - & - & - & - & 1,000 & 0,908 & 0,946 & 0,984 & 0,888 \\
\hline R. rhipicephali ${ }^{15}$ & - & - & - & - & - & - & - & - & - & - & - & - & - & - & 1,000 & 0,929 & 0,915 & 0,921 \\
\hline R. rickettsii ${ }^{16}$ & - & - & - & - & - & - & - & - & - & - & - & - & - & - & - & 1,000 & 0,955 & 0,899 \\
\hline R. sibirica ${ }^{17}$ & - & - & - & - & - & - & - & - & - & - & - & - & - & - & - & - & 1,000 & 0,895 \\
\hline R. felis PEDREIRA & - & - & - & - & - & _- & - & - & - & - & - & - & - & - & - & - & - & 1,000 \\
\hline
\end{tabular}


Tabela 23 - Grau de identidade calculado para cada par de seqüências de nucleotídeos, entre Rickettsia bellii cepa IXODES isolada de carrapato Ixodes loricatus de gambá, através do sequenciamento de DNA (gene gltA, 1.109 pb) e seqüências de Rickettsia spp do GenBank. 2006

\begin{tabular}{|c|c|c|c|c|c|c|c|c|c|c|c|c|c|c|c|c|c|c|c|c|c|}
\hline & $\begin{array}{c}R \\
\text { aes }\end{array}$ & $\begin{array}{l}R \\
\text { afr }\end{array}$ & $\begin{array}{c}R \\
\text { aka }\end{array}$ & $\begin{array}{c}R \\
a m b\end{array}$ & $\begin{array}{c}R \\
\text { aus }\end{array}$ & $\begin{array}{c}R \\
\text { bel }^{6}\end{array}$ & $\begin{array}{c}R \\
\text { bel }^{7}\end{array}$ & $\begin{array}{c}R \\
b e l^{8}\end{array}$ & $\begin{array}{c}R \\
\text { can } \\
\end{array}$ & $\begin{array}{c}R \\
\text { con } \\
\end{array}$ & $\begin{array}{c}R \\
\mathrm{fel}\end{array}$ & $\begin{array}{c}R \\
\text { hon }\end{array}$ & $\begin{array}{c}R \\
\text { jap }\end{array}$ & $\begin{array}{c}R \\
m o n\end{array}$ & $\begin{array}{c}R \\
\text { par }\end{array}$ & $\begin{array}{c}R \\
\text { pro }\end{array}$ & $\begin{array}{c}R \\
r h i\end{array}$ & $\begin{array}{l}R \\
\text { ric } \\
\end{array}$ & $\begin{array}{c}R \\
s i b \\
\end{array}$ & $\begin{array}{c}R \\
\text { typ }\end{array}$ & $\begin{array}{c}R \\
\text { bel I }\end{array}$ \\
\hline R. aeschlimannii ${ }^{1}$ & 1,000 & 0,959 & 0,911 & 0,957 & 0,92 & 0,841 & 0,84 & 0,84 & 0,886 & 0,961 & 0,915 & 0,961 & 0,958 & 0,962 & 0,963 & 0,903 & 0,962 & 0,954 & 0,964 & 0,901 & 0,841 \\
\hline R. africae $e^{2}$ & - & 1,000 & 0,939 & 0,982 & 0,947 & 0,865 & 0,864 & 0,864 & 0,912 & 0,99 & 0,939 & 0,991 & 0,988 & 0,986 & 0,993 & 0,930 & 0,984 & 0,984 & 0,994 & 0,925 & 0,865 \\
\hline R. $\operatorname{akari}^{3}$ & - & - & 1,000 & 0,937 & 0,971 & 0,856 & 0,855 & 0,855 & 0,894 & 0,941 & 0,947 & 0,94 & 0,936 & 0,944 & 0,94 & 0,911 & 0,941 & 0,935 & 0,941 & 0,912 & 0,856 \\
\hline R. amblyommi ${ }^{4}$ & - & - & - & 1,000 & 0,945 & 0,864 & 0,863 & 0,863 & 0,915 & 0,985 & 0,939 & 0,985 & 0,983 & 0,986 & 0,986 & 0,926 & 0,984 & 0,979 & 0,987 & 0,925 & 0,864 \\
\hline R. australis ${ }^{5}$ & - & - & - & - & 1,000 & 0,858 & 0,857 & 0,857 & 0,896 & 0,947 & 0,952 & 0,948 & 0,944 & 0,952 & 0,948 & 0,912 & 0,948 & 0,941 & 0,949 & 0,911 & 0,858 \\
\hline R. bellii $\mathrm{EUA}^{6}$ & - & - & - & - & - & 1,000 & 0,999 & 0,999 & 0,855 & 0,866 & 0,858 & 0,865 & 0,864 & 0,867 & 0,869 & 0,853 & 0,864 & 0,863 & 0,868 & 0,857 & 0,998 \\
\hline R. bellii RO $\mathrm{BRA}^{7}$ & - & - & - & - & - & - & 1,000 & 0,998 & 0,854 & 0,865 & 0,857 & 0,864 & 0,863 & 0,866 & 0,868 & 0,853 & 0,863 & 0,862 & 0,867 & 0,856 & 0,997 \\
\hline R. bellii Pe BRA $^{8}$ & - & - & - & - & - & - & - & 1,000 & 0,854 & 0,865 & 0,857 & 0,864 & 0,863 & 0,866 & 0,868 & 0,853 & 0,863 & 0,862 & 0,867 & 0,856 & 0,997 \\
\hline R. canadensis $^{9}$ & - & - & - & - & - & - & - & - & 1,000 & 0,915 & 0,91 & 0,915 & 0,914 & 0,917 & 0,915 & 0,893 & 0,913 & 0,910 & 0,915 & 0,897 & 0,855 \\
\hline$R$. conorii $^{10}$ & - & - & - & - & - & - & - & - & - & 1,000 & 0,941 & 0,994 & 0,990 & 0,99 & 0,995 & 0,931 & 0,988 & 0,990 & 0,996 & 0,930 & 0,866 \\
\hline R. felis $\mathrm{EUA}^{11}$ & - & - & - & - & - & - & - & - & - & - & 1,000 & 0,942 & 0,938 & 0,946 & 0,942 & 0,905 & 0,943 & 0,935 & 0,943 & 0,902 & 0,858 \\
\hline R. honei ${ }^{12}$ & - & - & - & - & - & - & - & - & - & - & - & 1,000 & 0,99 & 0,99 & 0,995 & 0,929 & 0,988 & 0,988 & 0,996 & 0,926 & 0,865 \\
\hline R. japonica ${ }^{13}$ & - & - & - & - & - & - & - & - & - & - & - & - & 1,000 & 0,987 & 0,990 & 0,928 & 0,985 & 0,983 & 0,991 & 0,927 & 0,864 \\
\hline R. montana ${ }^{14}$ & - & - & - & - & - & - & - & - & - & - & - & - & - & 1,000 & 0,990 & 0,932 & 0,989 & 0,985 & 0,991 & 0,930 & 0,867 \\
\hline R. parkeri ${ }^{15}$ & - & - & - & - & - & - & - & - & - & - & - & - & - & - & 1,000 & 0,931 & 0,989 & 0,989 & 0,999 & 0,928 & 0,869 \\
\hline R. prowazekii ${ }^{16}$ & - & - & - & - & - & - & - & - & - & - & - & - & - & - & - & 1,000 & 0,929 & 0,924 & 0,931 & 0,966 & 0,853 \\
\hline R. rhipicephali ${ }^{17}$ & - & - & - & - & - & - & - & - & - & - & - & - & - & - & - & - & 1,000 & 0,981 & 0,990 & 0,926 & 0,864 \\
\hline R. rickettsii ${ }^{18}$ & - & - & - & - & - & - & - & - & - & - & - & - & - & - & - & - & - & 1,000 & 0,990 & 0,923 & 0,863 \\
\hline R. sibirica ${ }^{19}$ & - & - & - & - & - & - & - & - & - & - & - & - & - & - & - & - & - & - & 1,000 & 0,928 & 0,868 \\
\hline R. typhi $i^{20}$ & - & - & - & - & - & - & - & - & - & - & - & - & - & - & - & - & - & - & - & 1,000 & 0,857 \\
\hline R. bellii IXODES & - & - & - & - & _ & - & - & - & - & - & - & - & - & - & - & - & - & - & - & - & 1,000 \\
\hline
\end{tabular}


Tabela 24 - Grau de identidade calculado para cada par de seqüências de nucleotídeos, entre Rickettsia bellii cepa IXODES isolada de carrapato Ixodes loricatus de gambá, através do sequenciamento de DNA (gene 17kDa, 376 pb) e seqüências de Rickettsia spp do GenBank. 2006

\begin{tabular}{|c|c|c|c|c|c|c|c|c|c|c|c|c|c|c|c|c|c|c|}
\hline & $\begin{array}{c}R \\
a k a\end{array}$ & $\begin{array}{c}R \\
a m b\end{array}$ & $\begin{array}{c}R \\
\text { aus } \\
\end{array}$ & $\begin{array}{c}R \\
b e l^{4} \\
\end{array}$ & $\begin{array}{c}R \\
\text { bel }^{5} \\
\end{array}$ & $\begin{array}{c}R \\
b e l^{6} \\
\end{array}$ & $\begin{array}{c}R \\
\text { can }\end{array}$ & $\begin{array}{c}R \\
\text { con } \\
\end{array}$ & $\begin{array}{c}R \\
f e l \\
\end{array}$ & $\begin{array}{c}R \\
\text { hon }\end{array}$ & $\begin{array}{c}R \\
m o n\end{array}$ & $\begin{array}{c}R \\
\text { par }\end{array}$ & $\begin{array}{c}R \\
\text { pro }\end{array}$ & $\begin{array}{c}R \\
r h i \\
\end{array}$ & $\begin{array}{l}R \\
\text { ric } \\
\end{array}$ & $\begin{array}{c}R \\
s i b \\
\end{array}$ & $\begin{array}{c}R \\
\text { typ } \\
\end{array}$ & $\begin{array}{c}R \\
\text { bel I } \\
\end{array}$ \\
\hline R. akari ${ }^{1}$ & 1,000 & 0,944 & 0,970 & 0,781 & 0,781 & 0,779 & 0,845 & 0,949 & 0,936 & 0,954 & 0,949 & 0,952 & 0,875 & 0,952 & 0,952 & 0,949 & 0,880 & 0,781 \\
\hline R. amblyommii ${ }^{2}$ & - & 1,000 & 0,962 & 0,784 & 0,784 & 0,781 & 0,845 & 0,978 & 0,936 & 0,984 & 0,978 & 0,981 & 0,877 & 0,976 & 0,981 & 0,978 & 0,880 & 0,784 \\
\hline R. australis ${ }^{3}$ & - & - & 1,000 & 0,787 & 0,787 & 0,784 & 0,859 & 0,962 & 0,952 & 0,968 & 0,962 & 0,965 & 0,882 & 0,965 & 0,965 & 0,962 & 0,888 & 0,787 \\
\hline R. bellii $\mathrm{EUA}^{4}$ & - & - & - & 1,000 & 0,994 & 0,992 & 0,816 & 0,800 & 0,781 & 0,795 & 0,792 & 0,797 & 0,776 & 0,797 & 0,797 & 0,795 & 0,779 & 0,994 \\
\hline R. bellii Pe $\mathrm{BRA}^{5}$ & - & - & - & - & 1,000 & 0,997 & 0,813 & 0,800 & 0,781 & 0,795 & 0,792 & 0,797 & 0,773 & 0,795 & 0,797 & 0,795 & 0,779 & 1,000 \\
\hline R. bellii $M g$ BRA $^{6}$ & - & - & - & - & - & 1,000 & 0,811 & 0,797 & 0,779 & 0,792 & 0,789 & 0,795 & 0,771 & 0,792 & 0,795 & 0,792 & 0,776 & 0,997 \\
\hline R. canadensis $^{7}$ & - & - & - & - & - & - & 1,000 & 0,851 & 0,864 & 0,856 & 0,853 & 0,853 & 0,808 & 0,859 & 0,853 & 0,856 & 0,797 & 0,813 \\
\hline R. conorii $^{8}$ & - & - & - & - & - & - & - & 1,000 & 0,936 & 0,994 & 0,984 & 0,997 & 0,877 & 0,981 & 0,997 & 0,994 & 0,880 & 0,800 \\
\hline R. felis $\mathrm{USA}^{9}$ & - & - & - & - & - & - & - & - & 1,000 & 0,941 & 0,936 & 0,938 & 0,880 & 0,938 & 0,938 & 0,941 & 0,880 & 0,781 \\
\hline R. honei ${ }^{10}$ & - & - & - & - & - & - & - & - & - & 1,000 & 0,989 & 0,997 & 0,882 & 0,986 & 0,997 & 0,994 & 0,885 & 0,795 \\
\hline R. montana ${ }^{11}$ & - & - & - & - & - & - & - & - & - & - & 1,000 & 0,986 & 0,888 & 0,984 & 0,986 & 0,984 & 0,888 & 0,792 \\
\hline R. parkeri $^{12}$ & - & - & - & - & - & - & - & - & - & - & - & 1,000 & 0,880 & 0,984 & 1,000 & 0,997 & 0,882 & 0,797 \\
\hline R. prowazekii ${ }^{13}$ & - & - & - & - & - & - & - & - & - & - & - & - & 1,000 & 0,888 & 0,880 & 0,877 & 0,952 & 0,773 \\
\hline R. rhipicephali ${ }^{14}$ & - & - & - & - & - & - & - & - & - & - & - & - & - & 1,000 & 0,984 & 0,981 & 0,885 & 0,795 \\
\hline R. rickettsii ${ }^{15}$ & - & - & - & - & - & - & - & - & - & - & - & - & - & - & 1,000 & 0,997 & 0,882 & 0,797 \\
\hline R. sibirica ${ }^{16}$ & - & - & - & - & - & - & - & - & - & - & - & - & - & - & - & 1,000 & 0,880 & 0,795 \\
\hline R. typhi $i^{17}$ & - & - & - & - & - & - & - & - & - & - & - & - & - & - & - & - & 1,000 & 0,779 \\
\hline R. bellii IXODES & - & - & - & - & - & - & - & - & - & - & - & - & - & - & - & - & - & 1,000 \\
\hline
\end{tabular}




\section{DISCUSSÃO}

No Brasil, são conhecidas três espécies de gambás: Didelphis albiventris (gambá de orelha branca) e Didelphis marsupialis e Didelphis aurita (gambás de orelha preta). Embora alguns autores tenham considerado no passado $D$. aurita como uma sub-espécie de $D$. marsupialis, atualmente é aceito pela comunidade científica a diferenciação em duas espécies. Sem diferenças significativas em relação à morfologia externa, essas espécies podem ser classificadas a partir de sua localização geográfica. D. marsupialis foi descrito somente na região amazônica, enquanto que $D$. aurita é encontrado na Bahia e nas regiões Sul e Sudeste do Brasil (CERQUEIRA; EMMORS; FEER, 1997; LEMOS; 2000). No presente trabalho, D. aurita foi encontrado na região de Mata Atlântica (São Paulo, Mogi das Cruzes) e na cidade de Pedreira. Nas cidades de Piracicaba e Pirassununga, situadas mais ao centro do Estado, verificou-se somente a presença de D. albiventris. Dentre os animais capturados, a grande maioria era de adultos, seguido por jovens e filhotes. O período de maior incidência de fêmeas com filhotes, ocorreu de julho a dezembro (HORTA et al., 2005a, c).

O critério adotado para escolha do número de colheita de amostras de sangue dos animais domésticos (cães, gatos e eqüinos) e dos humanos, nas diferentes localidades, foi a inclusão de todos os indivíduos presentes em cada sítio pesquisado. Nestas localidades, o número de amostras analisado de algumas espécies de hospedeiro (por exemplo, gatos em Pedreira) representou $100 \%$ de sua totalidade nos sítios de colheita. Os resultados obtidos organizados em dois conjuntos, um deles constituído por dados obtidos nas áreas com registros de casos 
de febre maculosa (grupo 1) e, o outro, por dados referentes à área onde a doença nunca fora notificada (grupo 2). Os resultados foram comparados entre si, através de análise estatística.

A razão sexual verificada nas pulgas Ctenocephalides felis felis, Polygenis (Neopolygenis) atopus e Rhopalopsyllus lutzi lutzi está de acordo com a encontrada na literatura (LINARDI; GUIMARÃES, 2000).

Ctenocephalides felis felis foi a espécie de maior prevalência em gambás, cães e gatos, o que evidencia o compartilhamento dessas pulgas entre animais silvestres e domésticos, devido à proximidade de seus habitats em ambientes suburbanos (AZAD et al., 1997; LINARDI; GUIMARAES, 2000). Em Pirassununga, os gambás não apresentaram parasitismo por essa espécie, possivelmente por terem sido capturados em ambiente menos degradado e em matas distantes de habitações humanas, o que diminui a proximidade destes marsupiais com os animais domésticos.

Os gambás vivem em áreas comuns aos hospedeiros primários dos carrapatos do gênero Amblyomma na natureza, podendo indicar o grau de infestação ambiental por carrapatos nas áreas onde vivem. No presente trabalho verificou-se o parasitismo nos marsupiais por carrapatos deste gênero, principalmente imaturos, em quatro das cinco áreas estudadas, com exceção do município de São Paulo. Nos sítios estudados deste município não se verificou uma população estabelecida deste grupo de carrapatos.

Foi possível relatar pela primeira vez, o encontro de larvas e ninfas de $A$. dubitatum (= A. cooperi) em gambás. Esta espécie de carrapato parasita preferencialmente capivaras, o que torna ainda mais intrigante a epidemiologia das riquétsias em áreas endêmicas, devido à interação que se estabelece entre os 
hospedeiros e potenciais reservatórios de riquétsias, através de seus diferentes ectoparasitos (LEMOS et al., 1996b).

Embora o encontro de Rickettsia felis em C. felis felis já tenha sido verificada em áreas endêmicas para febre maculosa em São Paulo (HORTA et al., 2005d), neste trabalho pôde-se avaliar uma maior diversidade de hospedeiros e uma maior quantidade de ectoparasitos permitindo inferência sobre a inter-relação entre eles. Em pulgas de gambás verificou-se uma alta prevalência de $R$. felis em $C$. felis felis $(45,8 \%)$; e uma baixa prevalência em pulgas $P$. (N.) atopus $(4,0 \%)$, representando o primeiro encontro da bactéria nessa espécie. As demais espécies se mostraram negativas para $R$. felis, o que sugere uma inter-relação harmoniosa entre Ctenocephalides sp/R. felis. Recentemente, nos EUA, foi investigada a presença de infecção natural por $R$. felis em 14 espécies diferentes de pulgas silvestres, tendo sido encontrada positividade em apenas dois indivíduos pertencentes a uma única espécie (Anomiopsyllus nudata), representando $0,8 \%$ do total (STEVENSON et al., 2005), compatível com os resultados do presente trabalho.

Sobre cães e gatos, respectivamente, $42,0 \%$ e $42,4 \%$ das C. felis felis foram encontradas infectadas pela bactéria. A transmissão transovariana implica em um importante mecanismo de manutenção da $R$. felis na natureza, o que pode justificar a alta prevalência encontrada. Todos os fragmentos de DNA seqüenciados de $R$. felis das pulgas foram idênticos entre si (gene gltA).

Neste trabalho, após análise estatística comparativa da prevalência de pulgas positivas de gambás e cães para $R$. felis, entre os grupos, verificou-se uma associação entre o encontro de pulgas infectadas e áreas com a presença de casos confirmados de febre maculosa. Contudo, em relação às pulgas de gatos, não houve diferença significativa. Mais estudos sobre capacidade e competência vetorial destes 
artrópodes precisam ser realizados. A falta de diagnóstico específico da riquetsiose causada pela $R$. felis constitui uma dificuldade no que diz respeito ao estudo natural da doença e que pode estar contribuindo para a ausência de dados sobre sua morbidade e letalidade.

No Brasil, além da C. felis felis, outra espécie pode ser encontrada de forma esporádica parasitando cães, Ctenocephalides canis, ocorrendo poucos relatos de infestações por esta espécie. A prevalência de infecção por $R$. felis foi verificada em C. felis felis $(70,8 \%)$ e C. canis $(29,2 \%)$, colhidas de cães em aldeias indígenas situadas dentro do município de São Paulo (HORTA et al., 2005b).

Neste estudo, registrou-se pela primeira vez, o encontro de Rickettsia bellii em um espécimen de pulga $P$. (N.) atopus colhido sobre gambá. É possível que o achado represente uma infecção acidental, uma vez que vários exemplares da mesma espécie, colhidos sobre o mesmo hospedeiro, foram negativos. $R$. bellii é uma bactéria de patogenicidade desconhecida e já foi descrito em diversos gêneros de carrapatos. Mais estudos são necessários para se determinar se esses artrópodes têm alguma participação no ciclo dessas riquétsias ou se apenas se infectaram através da co-alimentação com outros vetores infectados, durante o repasto sanguíneo, sobre um mesmo hospedeiro.

Embora existam indícios de infecção por $R$. felis em carrapatos, nenhum trabalho desenvolvido no país obteve êxito na adequada caracterização molecular e isolamento dessa espécie nesse tipo de vetor (CARDOSO et al., 2006; HORTA, 2002; PINTER, 2003; VIANNA, 2002). Em estudos semelhantes, verificou-se a presença de R. felis em carrapatos Haemaphysalis flava, Haemaphysalis kitasatoe e Ixodes ovatus no Japão (ISHIKURA et al., 2003) e em Haemaphysalis sulcata na Croácia (DUH et al., 2005). No presente trabalho, constatou-se a presença de duas 
larvas e duas ninfas de Amblyomma sp e dois Ixodes loricatus infectados com $R$. felis, identificadas através de pesquisa do gene gltA. Todos os fragmentos de DNA seqüenciados de $R$. felis dos carrapatos foram idênticos aos das pulgas, apresentando o mesmo grau de identidade entre si. Os dados ora apresentados dão suporte aos trabalhos anteriores, comprovando o encontro de $R$. felis em carrapatos e reforçam a hipótese sobre uma potencial participação destes artrópodes no ciclo desta riquétsia. No entanto, para que se possam incriminar essas espécies de carrapatos como potenciais vetores, necessita-se de mais estudos epidemiológicos, principalmente em relação à capacidade e competência vetorial desses artrópodes.

Em carrapatos de gambás, verificou-se através de estudo molecular, uma taxa de infecção por Ricketsia spp em 2,3\% dos carrapatos do gênero Amblyomma, sendo apenas $0,5 \%$ para riquétsia do GFM, o que está de acordo com a literatura registrada para esse gênero (LEMOS et al., 1997). Em carrapatos Ixodes loricatus, a prevalência de infecção por $R$. bellii foi de $59,1 \%$. Essa bactéria é considerada nãopatogênica para os mamíferos (PHILIP et al., 1983). A alta prevalência verificada em I. loricatus sugere que essa bactéria não tenha ação deletéria na população dessa espécie de carrapatos, diferentemente do que ocorre com bactérias do GFM, patogênicas ao homem, em seus vetores (NIEBYLSKI; PEACOCK; SCHWAN, 1999).

A partir de uma fêmea I. loricatus ingurgitada, positiva para $R$. bellii, colhida de um gambá no município de Mogi das Cruzes, foi possível o estabelecimento e manutenção de uma colônia em laboratório. A infecção nas gerações sucessiva foi avaliada pela PCR, o que permitiu verificar pela primeira vez a transmissão transovariana e a sobrevivência trans-estadial desta espécie de riquétsia neste artrópode (HORTA et al., 2005e). A partir de indivíduos da colônia foi possível o isolamento e 
cultivo de $R$. bellii em células VERO (cepa IXODES) (HORTA et al., 2005e). Adultos de I. loricatus são freqüentemente encontrados sobre marsupiais (gambás e cuícas) e os imaturos sobre roedores silvestres (ABEL et al., 2000; SCHUMAKER et al., 2000).

Pela primeira vez no país, foram realizados testes sorológicos de animais e humanos, frente aos antígenos de $R$. rickettsii, $R$. parkeri, $R$. felis e $R$. bellii, espécies notificadas na região Sudeste do país. A análise comparativa dos títulos de anticorpos específicos permitiu inferência sobre o possível agente etiológico causador da infecção no hospedeiro.

Pela análise estatística, somente o sorodiagnóstico dos eqüinos apresentou diferença entre os dois grupos estudados (endêmicos e não endêmicos) $(p<0,5)$ (Tabela 17), confirmando estudos anteriores (SANGIONI et al., 2005). Embora a prevalência de amostras reagente em gambás não tenha apresentado diferença significativa quanto às titulações entre os grupos analisados, verificou-se uma provável infecção por $R$. rickettsii em 10 indivíduos e por $R$. parkeri em dois outros, todos oriundos dos quatro municípios do grupo 1 (endêmico). Os títulos verificados contra essas riquétsias foram quatro vezes mais elevados do que aqueles referentes às demais espécies. Empregando-se o mesmo critério em Pirassununga (grupo 2), R. parkeri constitui a causa provável de infecção de um gambá. Portanto, esta área controle representa o único local estudado onde não foi possível se determinar uma provável infecção por $R$. rickettsii tanto em gambás como em outros hospedeiros (Tabela 19). Este fato associado à ausência de casos confirmados da doença no município e à observação de títulos mais baixos em relação aos verificados no grupo endêmico (Apêndices $A$ a $E$ ), sugere que a infecção por riquétsias nesse local seja 
causada por espécies menos virulentas, como R. parkeri (PADDOCK et al., 2004) e R. felis (GALVÃO et al., 2004, RAOULT et al., 2001).

Verificou-se humanos e animais reagentes a antígenos de $R$. felis que apresentaram títulos de anticorpos maiores para esta espécie (Apêndices $\mathrm{F}$ a J) em relação às outras. Porém, a infecção por essa espécie não pôde ser confirmada através da análise da resposta do hospedeiro frente aos diferentes antígenos testados (RIFI), segundo os critérios adotados, podendo se tratar de reação cruzada. No entanto, esses achados podem representar indícios de infecção por esse agente, o que poderia ser comprovado por técnicas de diagnóstico mais específicas ("crossadsorption", "western blotting") (JENSENIUS et al., 2004; LA-SCOLA; RAOULT, 1997).

Os hospedeiros primários de Amblyomma cajennense e Amblyomma aureolatum, respectivamente, eqüinos e cães, são considerados sentinelas da doença no país (HORTA et al., 2004; LEMOS et al., 1996a; PINTER, 2003). No presente trabalho, além destes hospedeiros, verificou-se também uma alta prevalência de gatos e gambás, hospedeiros secundários, com altos títulos antiRickettsia spp. Considerando-se os hábitos destes animais (domiciliar e/ou peridomiciliar), pode-se supor que em algumas áreas, na ausência dos hospedeiros primários, estes possam ser empregados como sinalizadores da circulação de riquétsias do grupo febre maculosa.

As amostras de sangue colhidas de gambás, cães, gatos, eqüinos e humanos mostraram-se negativas na pesquisa do gene gltA. A detecção de Rickettsia spp em sangue ocorre no período de bacteremia dos hospedeiros, isto é, durante o período da evolução desta doença aguda para a cura ou morte. Este fato pode justificar a negatividade observada nas amostras de sangue analisadas. 
A prevalência de um agente etiológico é, em princípio, maior entre seus reservatórios naturais. Porém, a pesquisa direta do agente no sangue de gambás, potenciais reservatórios naturais de riquétsias, também apresentaram resultados negativos. É necessário ressaltar, contudo, que no que se refere a riquétsias do GFM, o papel de reservatório precisa ser melhor esclarecido. Alguns mamíferos como, por exemplo, capivaras (TRAVASSOS; VALLEJO, 1942), apresentam uma bacteremia de curta duração, o que lhes confere um caráter de reservatórios temporários, isto é mamíferos amplificadores temporários. Neste curto período podem infectar vetores das riquétsias.

A análise dos resultados obtida no presente trabalho demonstra a presença de anticorpos anti-Rickettsia spp nos animais, inclusive em gambás, indicando fortemente a participação desses mamíferos como amplificadores das riquetsioses nas áreas investigadas. Estudos mais aprofundados devem ser realizados para se comprovar a duração da bacteremia nestes hospedeiros.

O isolamento e cultivo de $R$. felis foi realizado, de forma inédita, em uma linhagem de células de mosquito Aedes albopictus (C6/36). Estas células podem ser cultivadas a uma temperatura mais baixa, o que possibilitou a manutenção do agente no cultivo celular. Raoult et al. (2001) relataram o isolamento de $R$. felis pela primeira vez, em células de anfíbio Xenophus laevis (XTC-2), porém a taxa de infecção celular obtida não foi relatada. O presente estudo fornece um modelo eficiente de cultivo celular onde as células atingem $90-100 \%$ de infecção após alguns dias de incubação, a partir do isolamento primário (HORTA et al., 2006). Espera-se que essa técnica venha a contribuir para o desenvolvimento de novas pesquisas, particularmente sobre a epidemiologia de $R$. felis no âmbito mundial. 
O presente trabalho fornece subsídios para o entendimento da epidemiologia da febre maculosa no Estado de São Paulo, através da colheita de informações sobre o grau de participação dos potenciais hospedeiros de riquétsias e seus diferentes ectoparasitos.

Desta forma, espera-se que os resultados obtidos sirvam como base para estudos posteriores visando diagnóstico laboratorial mais específico e aspectos da capacidade e competência vetorial das diferentes espécies de artrópodes encontradas naturalmente infectadas. Adicionalmente, são necessários estudos sobre os diversos aspectos da interação entre as riquétsias e seus diferentes hospedeiros. 


\section{CONCLUSÕES}

No presente estudo foi possível:

1. identificar pulgas (Adoratopsylla (Adoratopsylla) antiquorum antiquorum, Ctenocephalides felis felis, Polygenis (Neopolygenis) atopus, Polygenies (Polygenis) roberti roberti, Polygenis (Polygenis) tripus, Polygenis (Polygenis) rimatus, Rhopalopsyllus lugubris lugubris e Rhopalopsyllus lutzi lutzi) e carrapatos (Amblyomma dubitatum, Amblyomma cajennense, Amblyomma aureolatum, Rhipicephalus sanguineus, Ixodes loricatus) colhidos em gambás, cães e gatos de áreas endêmicas e não endêmicas para febre maculosa do Estado de São Paulo;

2. verificar uma associação entre pulgas infectadas por Rickettsia felis, colhidas em gambás e cães, e áreas endêmicas para febre maculosa;

3. detectar a infecção por $R$. felis em pulgas Ctenocephalides felis felis de gambás (45,8\%), de cães (42,0\%) e de gatos (42,4\%); em Polygenis (Neopolygenis) atopus de gambás (4,0\%) e, em carrapatos, Amblyomma spp (0,7\%) e Ixodes loricatus $(1,8 \%)$;

4. detectar a infecção por $R$. bellii em carrapatos Ixodes loricatus $(59,1 \%)$, Amblyomma dubitatum (8,7\%) e Amblyomma spp (0,9\%) e em pulga $P$. (N.) atopus $(1 \%)$; 
5. detectar a infecção por Rickettsia amblyommii em carrapato Amblyomma cajennense $(1,2 \%)$;

6. detectar a infecção por Rickettsia sp do Grupo da Febre Maculosa em carrapatos Amblyomma spp (0,3\%);

7. verificar identidade de $100 \%$ entre as seqüências de $R$. felis encontradas nos vetores oriundos de diferentes regiões geográficas;

8. avaliar o sangue de animais e humanos das áreas estudadas, não tendo sido detectada a presença de Rickettsia spp;

9. constatar a presença de animais e humanos reagentes para antígenos de Rickettsia rickettsii, Rickttesia parkeri, R. felis e R. bellii;

10. sugerir, através da análise da titulação de anticorpos, infecção por $R$. rickettsii em humanos, gambás, cães, eqüinos e $R$. parkeri em gambás, cães e eqüinos;

11. verificar que células de mosquito $\mathrm{C} 6 / 36$ e células VERO foram eficazes no isolamento, respectivamente, de $R$. felis a partir de pulgas e de $R$. bellii partir de carrapatos. 
ABEL, I. S.; MARZAGÃO, G.; IOSINARI, N. H.; SCHUMAKER, T. T. S. Borrelia-like spirochetes recovered from ticks in the Atlantic Forest Reserve, Cotia County, State of São Paulo. Memórias do Instituto Oswaldo Cruz, v. 95, n. 5, p. 521-524, 2000.

ADAMS, J. R.; SCHMIDTMAN, E. T.; AZAD, A. F. Infection of colonized cat fleas Ctenocephalides felis (Bouché) with a Rickettsia-Like microorganism. American Journal of Tropical Medicine and Hygiene, v. 43, p. 400-409, 1990.

ARAGÃO, H.; FONSECA, F. Notas de Ixodologia. VII Lista e chave para os representantes da fauna ixodológica brasileira. Memórias do Instituto Oswaldo Cruz, v. 59, p. 115-129, 1961.

AZAD, A. F.; BEARD, C. B. Rickettsial pathogens and their arthropod vectors. Emerging Infectious Diseases, v. 4, n. 2, p. 179-186, 1998.

AZAD, A. F.; RADULOVIC, S.; HIGGINS, J. A.; NODEN, B. H.; TROYER, J. M. Fleaborne Rickettsioses: ecologic considerations. Emerging Infectious Diseases, v. 3, n. 3, p. 319-327, 1997.

AZAD, A. F.; SACCI-JR, J. B.; NELSON, W. M.; DASCH, G. A.; SCHMIDTMAN, E. T.; CARL M. Genetic characterization and transovarial transmission of a typhus-like Rickettsia found in cat fleas. Proceedings of the National Academy of Sciences of the United States of America, v. 89, p. 43-46, 1992.

AZAD, A. F.; WEBB, L.; CARL, M.; DASCH, G. A. Detection of Rickettsiae in arthropod vectors by DNA amplification using the polymerase chain reaction. Annals of New York Academy of Sciences, v. 590, p. 557-563, 1990.

BLAIR, P. J.; JIANG, J.; SCHOELLER, G. B.; MORON, C.; ANAYA, E.; CESPEDES, M.; CRUZ, C.; FELICES, V.; GUEVARA, C.; MENDOZA, L.; VILLASECA, P.; SUMNER, J. W.; RICHARDS, A. L.; OLSON, J. G.; Characterization of spotted fever group Rickettsiae in flea and tick specimens from northern Peru. Journal of Clinical Microbiology, v. 44, n. 11, p. 4961-4967, 2004.

\footnotetext{
${ }^{1}$ Conforme as diretrizes para apresentação de dissertações e teses da Faculdade de Medicina Veterinária e Zotecnia da universidade de São Paulo. $4^{a}$ ed. São Paulo: FMVZ-USP, 2003.
} 
BOUYER, D. H.; STENOS, J.; VALDES, P. C.; MORON, C. G.; POPOV, V. L.; ZAVALA-VELAZQUEZ, J. E.; FOIL, L. D.; STOTHARD, D. R.; AZAD, A. F.; WALKER, D. H. Rickettsia felis: molecular characterization of a new member of the spotted fever group. International Journal of Systematic and Evolutionary Microbiology, v. 51, p. 339-347, 2001.

BROUQUI, P.; BACELLAR, F.; BARANTON, G.; BIRTLES, R. J.; BJOERSDORFF, A.; BLANCO, J. R.; CARUSO, G.; CINCO, M.; FOURNIER, P. E.; FRANCAVILLA, E.; JENSENIUS, M.; KAZAR, J.; LAFERL, H.; LAKOS, A.; LOTRIC-FURLAN, S.; MAURIN, M.; OTEO, J. A.; PAROLA, P.; PEREZ-EID, C.; PETER, O.; POSTIC, D.; RAOULT, D.; TELLEZ, A.; TSELENTIS, Y.; WILSKE, B. Guideline for the diagnosis of tick-borne bacterial diseases in Europe. Clinical Microbiology and Infection, $\mathrm{V}$. 10, n. 12, p. 1108-1132, 2004.

CÁCERES, N. C.; MONTEIRO-FILHO, E. L. A. Foods habits, home range and activity of Didelphis aurita (Mammalia, Marsupialia) in a forest fragment of southern Brazil. Studies on Neotropical Fauna and Environment, v. 36, n. 2, p. 85-92, 2001.

CARDOSO, L. D.; FREITAS, R. N.; MAFRA, C. L.; NEVES, C. V. B.; FIGUEIRA, F. C. B.; LABRUNA, M. B.; GENNARI, S. M.; WALKER, D. H.; GALVÃO, M. A. M. Caracterização de Rickettsia spp circulante em foco silencioso de febre maculosa brasileira no Município de Caratinga, Minas Gerais, Brasil. Caderno de Saúde Pública, v. 22, n. 3, p. 495-501, 2006.

CERQUEIRA, R.; LEMOS, B. Morphometric differentiation between neotropical black-eared opossums, Didelphis marsupialis and D. aurita (Didelphimorphia, Didelphidae). Mammalia, v. 64, n. 3, p. 319-327, 2000.

CVE - CENTRO DE VIGILÂNCIA EPIDEMIOLÓGICA. Distribuição dos casos confirmados de febre maculosa segundo município provável de infecção no Estado de São Paulo: 1985-2005. Disponível em: <http://www.cve.saude.sp.gov.br/htm/zoo/fm d9803.htm>. Acesso em: 26 mar. 2006.

DIAS, E.; MARTINS, A. V. Spotted Fever in Brazil. American Journal of Tropical Medicine, v. 19, p. 103-108, 1939.

DUH, D. PUNDA-POLIC, V.; PETROVEC, M.; TRILAR, T.; BRADARIC, N.; AVSICZUPANA, T. Molecular identification of flea-transmitted Rickettsia felis-like bacteria in Haemaphysalis sulcata ticks collected from domestic animals in southern Croatia. In: INTERNATIONAL CONFERENCE ON RICKETTSIAE AND RICKETTSIAL DISASES, 4, 2005b, Logroño, Espanha. Anais... res. P-123. 
EMMORS, L. H.; FEER, F. Neotropical rainforest mammals - a field guide, 2. ed. Chicago; London: The University of Chicago Press. 1997. 307 p.

EREMEEVA, M. E.; DASCH, G. A. Rickettsiae. In: LEDERBERG, J. Encyclopedia of microbiology, New York: Academic Press, 2000. v. 4, p. 140-180.

EREMEEVA, M. E.; YU, X.; RAOULT, D. Differentiation among Spotted Fever Group Rickettsiae species by analysis of restriction fragment lenght polymorphism of PCRamplified DNA. Journal of Clinical Microbiology, v. 32, n. 3, p. 803-810, 1994.

FONTES, L. R.; GOMES, S. M. A.; ANJOS, E. D.; ANDRADE, J. C. R. Brazilian Spotted Fever transmited by Amblyomma aureolatum (ACARI) in Mogi das Cruzes, Brazil: Report of four humans cases and environmental control measures. In: INTERNATIONAL CONGRESS OF ENTOMOLOGY, 21., 2000, Brasil. Anais... p. 749.

GALVÃO, M. A. M.; MAFRA, C.; CHAMONE, C. B.; CALIC, S. B.; ZAVALAVELAZQUEZ, J. E.; WALKER, D. H. Clinical and laboratorial evidence of Rickettsia felis infections in Latin America. Revista da Sociedade Brasileira de Medicina Tropical, v. 37, n. 3, p.238-240, 2004.

GEHRKE, F.; NASCIMENTO, E. M. M.; SOUZA, E. R.; COLOMBO, S.; SILVA, L. J.; SCHUMAKER, T. T. S. Detection of Rickettsia rickettsii and Rickettsia sp in 24 patient blood clots from different municipalities of the State of São Paulo. In: INTERNATIONAL CONFERENCE ON RICKETTSIAE AND RICKETTSIAL DISASES, 4, 2005, Logroño, Espanha. Anais... res. P-164.

GIMÉNEZ, D. F. Staining Rickettsiae in yolk-sac cultures. Stain Technology, v. 39, n. 3, p. 135-140, 1964.

HALL, T. A. BioEdit: a user-friendly biological sequence alignment editor and analysis program for Windows 95/98/NT. Nucleic Acids Symposium Series, v. 41, P. 95-98. 1999.

HIGGINS, J. A.; RADULOVIC, S.; SCHRIEFER, M. E.; AZAD, A. F. Rickettsia felis: A new species of pathogenic Rickettsia isolated from cat fleas. Journal of Clinical Microbiology, v. 34, n. 3, p. 671-674, 1996.

HIGGINS, J. A.; SACCI, J. B. J.; SCHRIEFER, M. E.; ENDRIS, R. G.; AZAD, A. F. Molecular identification of Rickettsia-like microorganisms associated with colonized cat fleas (Ctenocephalides felis). Insect Molecular Biology, v. 3, p. 27-33, 1994. 
HORTA, M. C. Pesquisa de Infecção por Riquétsias do Grupo da Febre Maculosa em Humanos, Eqüídeos, Caninos e em Diferentes Estádios de Vida de Amblyomma cajennense, Provenientes de uma Área Endêmica do Estado de São Paulo. 2002. 72 f. Dissertação (Mestrado Medicina Veterinária). Faculdade de Medicina Veterinária e Zootecnia, Universidade de São Paulo, SP, 2002.

HORTA, M. C.; BERTOLA, P. B.; FERREIRA, P. M.; BATAGLIOLI, M. C.; SCHUMAKER, T. T. S. Análise populacional de Didelphis aurita e D. albiventris no Estado de São Paulo. In: CONGRESSO BRASILEIRO DE MASTOZOOLOGIA, 3, 2005, Aracruz/ES. Anais... 2005a. p. 21.

HORTA, M. C.; CHIEBAO, D. P.; SOUZA, D. B.; FERREIRA, F.; PINHEIRO, S. R.; LABRUNA, M. B.; SCHUMAKER, T. T. S. Prevalence of Rickettsia felis in the fleas Ctenocephalides felis felis and Ctenocephalides canis from two Indian communities in São Paulo municipality, Brazil. In: INTERNATIONAL CONFERENCE ON RICKETTSIAE AND RICKETTSIAL DISASES, 4, 2005b, Logroño, Espanha. Anais... res. P-165.

HORTA, M. C.; FERREIRA, P. M.; GERALDI, V. C.; SUMMA, M. E. L.; ROSSI, F. W.; JOPPERT, A. M.; BERTOLA, P. B.; FERREIRA, F.; SCHUMAKER, T. T. S. Mapeamento da distribuição de gambás (Didelphis $\mathrm{sp}$ ) capturados no município de São Paulo e avaliação do parasitismo por pulgas. In: CONGRESSO BRASILEIRO DE MASTOZOOLOGIA, 3, 2005c, Aracruz/ES. Anais... p. 31.

HORTA, M. C.; LABRUNA, M. B.; DURIGON, E. L.; SCHUMAKER, T. T. S. Isolation and Cultivation of Rickettsia felis in the mosquito cell line C6/36. Applied and Environmental Microbiology, v. 72, n. 2, p. 1705-1707, 2006.

HORTA, M. C.; PINTER, A.; CORTEZ, A.; SOARES, R. M.; GENNARI, S. M.; SCHUMAKER, T. T. S.; LABRUNA, M. B. Rickettsia felis (Rickettsiales:

Rickettsiaceae) in Ctenocephalides felis felis (Siphonaptera: Pulicidae) in the State of São Paulo, Brazil. Arquivo Brasileiro de Medicina Veterinária e Zootecnia, v. 57, n. 3, p. 321-325, 2005d.

HORTA, M. C.; PINTER, A.; SCHUMAKER, T. T. S.; LABRUNA, M. B. Natural infection, transovarial transmission, and transstadial survival of Rickettsia bellii in the tick Ixodes loricatus (Acari: Ixodidae) from Brazil. INTERNATIONAL CONFERENCE ON RICKETTSIAE AND RICKETTSIAL DISASES, 4, 2005e, Logroño, Espanha. Anais... res. O-55. 
HORTA, M. C.; SANGIONI, L. A.; VIANNA, M. C.; SCHUMAKER, T. T. S.;

LABRUNA, M. B.; WALKER, D. H. Prevalence of antibodies to spotted fever group Rickettsiae in humans and domestic animals in a Brazilian spotted fever-endemic area in the State of São Paulo, Brazil: serologic evidence for infection by Rickettsia rickettsii and another spotted fever group Rickettsia. American Journal of Tropical Medicine and Hygiene, v. 71, n. 1, p.93-97, 2004.

IGARASHI, A. Isolation of a Singh's Aedes albopictus cell clone sensitive to dengue and chikungunya viruses. The Journal of General Virology, v. 40, p. 531-544, 1978.

ISHIKURA, M.; ANDO, S.; SHINAGAWA, Y.; MATSUURA, K.; HASEGAWA, S.; NAKAYAMA, T.; FUJITA, H.; WATANABE, M. Phylogenetic analysis of spotted fever group Rickettsiae based on gltA, 17-kDa, and rOmpA genes Amplified by nested PCR from ticks in Japan. Microbiology and Immunology, v. 47, n. 11, p. 823-832, 2003.

JENSENIUS, M.; FOURNIER, P. E.; VENE, S.; RINGERTZ, S. H.; MYRVANG, B.; RAOULT, D. Comparison of immunofluorescence, western blotting, and crossadsorption assays for diagnosis of African Tick Bite Fever. Clinical and Diagnostic Laboratory Immunology, v. 11, n.4, p. 786-788, 2004.

KELLY, P. J.; MEADS, N.; THEOBALD, A.; FOURNIER, P. E.; RAOULT, D. Rickettsia felis, Bartonella henselae, and B. clarridgeiae, New Zealand. Emerging Infectious Diseases, v. 10, n. 5, p. 967-968, 2004.

KELLY, P. J.; RAOULT, D.; MASON, P. R. Isolation of Spotted Fever Group Rickettsias from triturated ticks using a modification of the centrifugation-shell vial technique. Transactions of the Royal Society of Tropical Medicine and Hygiene, v. 85, p.397-398, 1991.

KENNY, M. J.; BIRTLES, R. J.; DAY, M. J.; SHAW, S. E. Rickettsia felis in the United Kingdom. Emerging Infectious Diseases, v. 9, n. 8, p. 1023-1024, 2003.

LABRUNA, M. B.; CAMARGO, L. M. A.; CAMARGO, E. P.; WALKER, D. H. Detection of a spotted fever group Rickettsia in the tick Haemaphysalis justakochi in Rondonia, Brazil. Veterinary Parasitology, v. 127, p. 169-174, $2005 a$.

LABRUNA, M. B.; WHITWORTH, T.; BOUYER, D. H.; MCBRIDE, J.; CAMARGO, L. M. A.; CAMARGO, E. P.; POPOV, V.; WALKER, D. H. Rickettsia bellii and Rickettsia amblyommii in Amblyomma ticks from the state of Rondônia, western Amazon, Brazil. Journal of Medical Entomology, v. 41, n. 6, p. 1073-1081, 2004b. 
LABRUNA, M. B.; WHITWORTH, T.; HORTA, M. C.; BOUYER, D. H.; McBRIDE, J. W.; PINTER, A.; POPOV, V., GENNARI, S. M.; WALKER, D. H. Rickettsia species infecting Amblyomma cooperi ticks from an area in the state of São Paulo, Brazil, where brazilian spotted fever is endemic. Journal of Clinical Microbiology, v. 42, n. 1, p. 90-98, 2004a.

LA-SCOLA, B.; RAOULT, D. Laboratory diagnosis of rickettsioses: current approaches to diagnosis of old and new rickettsial diseases. Journal of Clinical Microbiology, v. 35, n. 11, p. 2715-2727, 1997.

LEMOS, E. R. S.; MACHADO, R. D.; COURA, J. R.; GUIMARÃES, M. A. A. M.; CHAGAS, N. Epidemiological Aspects of the Brazilian Spotted Fever: Serological Survey of Dogs and Horses in an Endemic Area in the State of São Paulo, Brazil. Revista do Instituto de Medicina Tropical de São Paulo, v. 36, n. 6, p. 427-430, 1996a.

LEMOS, E. R. S.; MELLES, H. H. B.; COLOMBO, S.; MACHADO, R. D.; COURA, J. R.; GUIMARÃES, M. A. A.; SANSEVERINO, S. R.; MOURA, A. Primary isolation of Spotted Fever Group Rickettsiae from Amblyomma cooperi collected from Hydrochaeris hydrochaeris in Brazil. Memórias do Instituto Oswaldo Cruz, v. 91, p. 273-275, 1996b.

LEMOS, E. R. S.; MACHADO, R. D.; PIRES, F. D. A.; MACHADO, S. L.; COSTA, L. M. C.; COURA, J. R. Rickettsiae-infected ticks in an endemic area of Spotted Fever in the State of Minas Gerais, Brazil. Memórias do Instituto Oswaldo Cruz, v. 92, n. 4, p. 477-481, 1997.

LINARDI, P. M.; GUIMARÃES, L. R. Sifonápteros do Brasil. São Paulo: Museu de Zoologia USP/FAPESP, 2000. 291p.

MÁRQUEZ, F. J.; MUNIAN, M. A.; PÉREZ, J. M.; PACHÓN, J. Presence of Rickettsia felis in the cat flea from Southweastern Europe. Emerging Infectious Diseases, v. 8, n. 1, p. 89-91, 2002.

MOREIRA, J. A.; MAGALHAES, O. Typho exanthematico em Minas Gerais. BrasilMedico, v. 21, p. 465-470, 1935.

NASCIMENTO, E. M.; GEHRKE, F. S.; MALDONADO, R. A.; COLOMBO, S.; SILVA, L. J.; SCHUMAKER, T. T. S. Detection of a Brazilian spotted fever infection by polymerase chain reaction in a patient from the state of São Paulo. Memórias do Instituto Oswaldo Cruz, v. 100, n. 3, p. 277-279, 2005. 
NIEBYLSKI, M. L.; PEACOCK, M. G.; SCHWAN, T. G. Lethal effect of Rickettsia rickettsii on its tick vector (Dermacentor andersoni). Applied and Environmental Microbiology, v. 65, n. 2, p. 773-338, 1999.

NODEN, B. H.; RADULOVIC, S.; HIGGINS, J. A.; AZAD, A. F. Molecular Identification of Rickettsia typhi and Rickettsia felis in co-infected Ctenocephalides felis (Siphonaptera: Pulicidae). Journal of Medical Entomology, v. 35, n. 4, p. 410414, 1998.

OGATA, H.; RENESTO, P.; AUDIC, S.; ROBERT, C.; BLANC, G.; FOURNIER, P. E.; PARINELLO, H.; CLAVERIE, J. M.; RAOULT, D. The genome sequence of Rickettsia felis identifies the first putative conjugative plasmid in an obligate intracellular parasite. PLoS Biology, v. 3, n. 8, p. 1-12, 2005.

OLIVEIRA, R. P.; GALVÃO, M. A. M.; MAFRA, C. L.; CHAMONE, C. B.; CALIC, S. B.; SILVA, S. U.; WALKER, D. H. Rickettsia felis in Ctenocephalides spp fleas, Brazil. Emerging Infectious Diseases, v. 8, n. 3, p. 317-319, 2002.

PADDOCK, C. D.; SUMMER, J. W.; COMER, J. A.; ZAKI, S. R.; GOLDSMITH, C. S.; GODDARD, J.; McLELAN, S. L. F.; TAMMINGA, C. L.; OHL, C. A. Rickettsia parkeri: a newly recognized cause of spotted fever rickettsiosis in the United States. Clinical Infectious Diseases, v. 38, n. 15, p. 805-811, 2004.

PAROLA, P.; SANOGO, O. Y.; LERDTHUSNEE, K.; ZEAITER, Z.; CHAUVANCY, G.; GONZALEZ, J. P.; MILLER, R. S.; TELFORD III, S. R.; WONGSRICHANALAI, C.; RAOULT, D. Identification of Rickettsia spp. and Bartonella spp. in fleas from the Thai-Myanmar border. Annals of the New York Academy of Sciences, v. 990, p. 173-181, 2003.

PHILIP, R. N.; CASPER, E. A.; BURGDORFER, W.; GERLOFF, R. K.; HUGHES, L. E.; BELL. E. J. Serologic typing of Rickettsiae of the Spotted Fever Group by microimmunofluorescence. The Journal of Immunology, v. 121, n. 5, p. 1961-1968, 1978.

PHILIP, R. N.; CASPER, E. A.; ANACKER, R. L.; CORY, J.; HAYES, S. F.; BURGDORFER, W.; YUNKER, E. Rickettsia bellii sp. Nov.: a tick-borne Rickettsia, widely distributed in the United States, that is distinct from the spotted fever and thyphus biogroups. International Journal of Systematic Bacteriology, v. 33, n. 1, p. 94-106, 1983. 
PINTER, A. Aspectos epidemiológicos da febre maculosa em uma área endêmica do município de Mogi das Cruzes (SP) e estudo em laboratório do ciclo de vida do vetor Amblyomma aureolatum (Acari: Ixodidae). 2003. $100 \mathrm{f}$. Dissertação (Mestrado em Medicina Veterinária). Faculdade de Medicina Veterinária e Zootecnia, Universidade de São Paulo, São Paula, 2003.

PINTER, A.; LABRUNA, M. B. Isolation of Rickettsia rickettsii and Rickettsia bellii in cell culture from the tick Amblyomma aureolatum in Brazil. INTERNATIONAL CONFERENCE ON RICKETTSIAE AND RICKETTSIAL DISASES, 4, 2005, Logroño, Espanha. Anais... res. O-54.

RADULOVIC, S.; HIGGINS, J. A.; JAWORSKI, D. C.; AZAD, A. F. In vitro and in vivo antibiotic susceptibilities of ELB rickettsiae. Antimicrobial Agents and

Chemotherapy, v. 39, p. 2564-2566, 1995.

RADULOVIC, S.; HIGGINS, J. A.; JAWORSKI, D. C.; AZAD, A. F. In vitro and in vivo antibiotic susceptibilities of ELB rickettsiae (erratum). Antimicrobial Agents and Chemotherapy, v. 40, p. 2912, 1996.

RAOULT, D.; FOURNIER, P. E.; ABBOUD, P.; CARON, F. First documented human Rickettsia aeschlimannii infection. Emerging Infectious Diseases, v. 8, n. 7, p. 748749, 2002.

RAOULT, D.; LA-SCOLA, B.; ENEA, M.; FOURNIER, P. E.; ROUX, V.; FENOLLAR, F.; GALVÃO, M. A. M.; LAMBALLERIE, X. D. A flea-associated Rickettsia pathogenic for humans. Emerging Infectious Diseases, v. 7, n. 1, p. 73-81, 2001.

RAOULT, D.; ROUX, V. Rickettsioses as paradigms of new or emerging infectious diseases. Clinical Microbiology Reviews, v. 10, p. 694-719, 1997.

RICHTER, J.; FOURNIER, P. E.; PETRIDOU, J.; HAUSSINGER, D.; RAOULT, D. Rickettsia felis infection acquired in Europe and documented by Polymerase Chain Reaction. Emerging Infectious Diseases, v. 8, n. 2, p. 207-208, 2002.

ROLAIN, J. M.; BOURRY, O.; DAVOUST, B.; RAOULT, D. Bartonella Quintana and Rickettsia felis in Gabon. Emerging Infectious Diseases, v. 11, n. 11, p. 1742-1744, 2005.

ROUX, V.; RAOULT, D. Phylogenetic analysis of members of the genus Rickettsia using the gene encoding the outer-membrane protein $\mathrm{rOmpB}(\mathrm{OmpB})$. International Journal of Systematic and Evolutionary Microbiology, v. 50, p. 1449-1455, 2000. 
SAMBROOK, J.; FRITSCH, E. F.; MANIATIS, T. Molecular Cloning: a laboratory Manual. 2. ed. Cold Spring Harbor, Cold Spring Harbor Laboratory Press, 1989.

SANGIONI, L. A.; HORTA, M. C.; VIANNA, M. C. B.; GENNARI, S. M.; SOARES, R. M.; GALVÃO, M. A. M.; SCHUMAKER, T. T. S.; FERREIRA, F.; VIDOTTO, O.; LABRUNA, M. B. Rickettsial infection in animals and Brazilian Spotted Fever endemicity. Emerging Infectious Diseases, v. 11, n. 2, p. 265-270, 2005.

SCHRIEFER, M. E.; SACCI-JR; J. B.; DUMLER, J. S.; BULLEN, M. G.; AZAD, A. F. Identification of a novel Rickettsial infection in a patient diagnosed with murine typhus. Journal of Clinical Microbiology, v. 32, p. 949-954, 1994a.

SCHRIEFER, M. E.; SACCI-JR, J. B.; TAYLOR, J. P.; HIGGINS, J. A.; AZAD, A. F. Murine Typhus: update roles of multiple urban components and a second typhuslike Rickettsia. Journal of Medical Entomology, v. 31, p. 681-685, $1994 \mathrm{~b}$.

SCHUMAKER, T. T. S.; LABRUNA, M. B.; ABEL, I. S.; CLERICI, P. T. S. Lyfe cycle of Ixodes (Ixodes) loricatus (Acari: Ixodidae) under laboratory conditions. Journal of Medical Entomology, v. 37, n. 5, p. 714-720, 2000.

SEKEYOVA, Z.; ROUX, V.; RAOULT, D. Phylogeny of Rickettsia spp inferred by comparing sequences of 'gene $D$ ', which encodes an intracytoplasmic protein. International Journal of Systematic and Evolutionary Microbiology, v. 51, p. 1353-1360, 2001.

SEXTON, D. J.; MUNIZ, M.; COREY, G. R.; BREITSCHWERDT, E. B.; HEGARTY, B. C.; DUMLER, S.; WALKER, D. H.; PECANHA, P. M.; DIETZE, R. Brazilian spotted fever in Espírito Santo, Brazil: description of a focus of infection in a new endemic region. American Journal of Tropical Medicine and Hygiene, v. 49, n. 2, p. $222-$ 226, 1993.

SHAW, S. E.; KENNY, M. J.; TASKER, S.; BIRTLES, R. J. Pathogen carriage by the cat flea Ctenocephalides felis (Bouché) in the United Kingdom. Veterinary Microbiology, v. 102, p. 183-188, 2004.

SILVEIRA, I.; PACHECO, R. C.; SZABÓ, M. P.; CASTRO, M. B.; PETERKA, C. R. L.; VERONEZ, V. A.; GARCIA, M. V.; PRETTE, N.; PEREIRA, L. F.; ROCHA, H.; LABRUNA, M. B. Isolamento de Ricekttsia parkeri em cultura de células Vero a partir do carrapato Amblyomma triste. In: CONGRESSO BRASILEIRO DE PARASITOLOGIA, 19., 2005, Porto Alegre. Anais... v. 34. 
SORVILLO, F. J.; GONDO, B.; EMMONS, R.; RYAN, P.; WATERMAN, S. H. TILZER, A. A suburban focus of Endemic Typhus in Los Angeles County: association with seropositive domestic cats and opossums. American Journal of Tropical Medicine and Hygiene, v. 48, p. 269-273, 1993.

STEVENSON, H. L.; LABRUNA, M. B.; MONTENIERI, J. A.; KOSOV, M. Y.; GAGE, K. L.; WALKER, D. H. Detection of Rickettsia felis in a new world flea species, Anomiopsyllus nudata (Siphonaptera: Ctenophthalmidae). Journal of Medical Entomology, v. 42, n. 2, p. 163-167, 2005.

STOTHARD, D. R.; FUERST, P. A. Evolutionary analysis of the Spotted Fever and Typhus Group Rickettsiae using 16S rRNA gene sequences. Systematic and Applied Microbiology, v. 18, p.52-61, 1995.

TRAVASSOS, J.; VALLEJO, A. Comportamento de alguns cavídeos (Cavia aperea e Hydrochoerus capybara) às inoculações experimentais do vírus da Febre Maculosa. Possibilidade desses cavídeos representarem o papel de depositários transitórios do vírus na natureza. Memórias do Instituto Butantã, v. 15, p. 73-86, 1942.

VENZAL, J. M.; PÉREZ-MARTINEZ, L.; FÉLIX, M. L.; PORTILLO, A.; BLANCO, J. R.; OTEO, J. A. Prevalence of Rickettsia felis in Ctenocephalides felis and Ctenocephalides canis from Uruguay. In: INTERNATIONAL CONFERENCE ON RICKETTSIAE AND RICKETTSIAL DISASES, 4, 2005, Logroño, Espanha. Anais... res. O-63.

VIANNA, M. C. B. Pesquisa de Infecção por Riquétsia do Grupo da Febre Maculosa em Humanos, Cães, Eqüídeos e em Adultos de Carrapatos Amblyomma cajennense em uma Área Endêmica do Estado de Minas Gerais. 2002. 67 f. Dissertação (Mestrado em Medicina Veterinária). Faculdade de Medicina Veterinária e Zootecnia, Universidade de São Paulo, São Paulo, 2002.

WALKER, D. H.; LIU, Q. H.; YU, X. L.; LI, H.; TAYLOR, C.; FENG, H. M. Antigenic diversity of Rickettsia conorii. American Journal of Tropical Medicine and Hygiene, v. 47, p. 78-86, 1992.

WEBB, L.; CARL, M.; MALLOY, D. C.; DASCH, G. A.; AZAD, A. F. Detection of Murine Typhus infection in fleas by using the polymerase chain reaction. Journal of Clinical Microbiology, v. 28, n. 3, p. 530-534, 1990.

WEDINCAMP, J.; FOIL, L. D. Vertical Transmission of Rickettsia felis in the cat flea (Ctenocephalides felis Bouché). Journal of Vector Ecology, v. 27, n. 1, p. 96-101, 2002. 
ZAVALA-VELÁZQUEZ, J. E.; RUÍZ-SOSA, J. A.; SÁNCHEZ-ELIAS, R. A.; BECERRA-CARMONA, G.; WALKER, D. H. Rickettsia felis rickettsiosis in Yucatán. Lancet, v. 356, p. 1079-1080, 2000.

ZAVALA-VELÁZQUEZ, J. E.; ZAVALA-CASTRO, J. E.; VADO-SOLÍS, I.; RUIZSOSA, J. A.; MORON, C. G.; BOUYER, D. H.; WALKER, D. H. Identification of Ctenocephalides felis fleas as a host of Rickettsia felis, the agent of a spotted fever ricketsiosis in Yucatán, Mexico. Vector Borne and Zoonotic Diseases, v. 2, n. 2, p. 69-75, 2002.

ZNAZEN, A.; ROLAIN, J. M.; HAMMAMI, N.; HAMMAMI, A.; JEMMA, M. B.; RAOULT, D. Rickettsia felis infection, Tunisia. Emerging Infectious Diseases, v. 12, n.1, p.138-140, 2006. 


\section{APÊNDICE A}

Títulos de anticorpos anti-Rickettsia rickettsii em gambás do Estado de São Paulo, verificados através da reação de imunofluorescência indireta

\begin{tabular}{lccccccccccc}
\hline Cidades/Titulação & $\mathbf{( + )}$ & $\mathbf{6 4}$ & $\mathbf{1 2 8}$ & $\mathbf{2 5 6}$ & $\mathbf{5 1 2}$ & $\mathbf{1 0 2 4}$ & $\mathbf{2 0 4 8}$ & $\mathbf{4 0 9 6}$ & $\mathbf{8 1 9 2}$ & $(-\boldsymbol{-})$ & Total \\
\hline Pedreira & 11 & 2 & 2 & 2 & 2 & 1 & 2 & - & - & 3 & 14 \\
Piracicaba* $_{\text {São Paulo }}^{11}$ & 2 & - & 2 & 3 & 1 & - & 1 & 1 & 6 & 17 \\
Pirassununga & 18 & 2 & 6 & 2 & 4 & 4 & - & - & - & 17 & 35 \\
Mogi das Cruzes & 6 & 1 & 3 & 2 & - & - & - & - & - & 6 & 12 \\
\hline Total & 10 & 2 & - & 4 & 1 & 2 & 1 & - & - & 6 & 16 \\
\hline
\end{tabular}

* (1) 32.768

Títulos de anticorpos anti-Rickettsia parkeri em gambás do Estado de São Paulo, verificados através da reação de imunofluorescência indireta

\begin{tabular}{lccccccccccc}
\hline Cidades/Titulação & $\mathbf{( + )}$ & $\mathbf{6 4}$ & $\mathbf{1 2 8}$ & $\mathbf{2 5 6}$ & $\mathbf{5 1 2}$ & $\mathbf{1 0 2 4}$ & $\mathbf{2 0 4 8}$ & $\mathbf{4 0 9 6}$ & $\mathbf{8 1 9 2}$ & $(-)$ & Total \\
\hline Pedreira & 10 & 2 & 3 & 2 & 2 & 1 & - & - & - & 4 & 14 \\
Piracicaba & 12 & 1 & 5 & 2 & 2 & - & - & 2 & - & 5 & 17 \\
São Paulo & 19 & 3 & 7 & 4 & 4 & 1 & - & - & - & 16 & 35 \\
Pirassununga & 6 & - & 3 & 2 & - & 1 & - & - & - & 6 & 12 \\
Mogi das Cruzes & 8 & 1 & - & 3 & 4 & - & - & - & - & 8 & 16 \\
\hline Total & $\mathbf{5 5}$ & $\mathbf{7}$ & $\mathbf{1 8}$ & $\mathbf{1 3}$ & $\mathbf{1 2}$ & $\mathbf{3}$ & - & $\mathbf{2}$ & - & $\mathbf{4 0}$ & $\mathbf{9 4}$ \\
\hline
\end{tabular}

Títulos de anticorpos anti-Rickettsia felis em gambás do Estado de São Paulo, verificados através da reação de imunofluorescência indireta

\begin{tabular}{llllllllllllll}
\hline Cidades/Titulação & $(+)$ & 64 & 128 & 256 & 512 & 1024 & 2048 & 4096 & 8192 & $(-)$ & Total
\end{tabular}

\begin{tabular}{lccccccccccc}
\hline Pedreira & 9 & 6 & 3 & - & - & - & - & - & - & 5 & 14 \\
Piracicaba & 11 & 5 & 2 & 2 & 1 & - & 1 & - & - & 6 & 17 \\
São Paulo & 6 & - & 4 & 2 & - & - & - & - & - & 29 & 35 \\
Pirassununga & 4 & 3 & - & 1 & - & - & - & - & - & 8 & 12 \\
Mogi das Cruzes & 3 & 1 & - & 1 & 1 & - & - & - & - & 13 & 16 \\
\hline Total & $\mathbf{3 3}$ & $\mathbf{1 5}$ & $\mathbf{9}$ & $\mathbf{6}$ & $\mathbf{2}$ & - & $\mathbf{1}$ & - & - & $\mathbf{6 1}$ & $\mathbf{9 4}$ \\
\hline
\end{tabular}

Títulos de anticorpos anti-Rickettsia bellii em gambás do Estado de São Paulo, verificados através da reação de imunofluorescência indireta

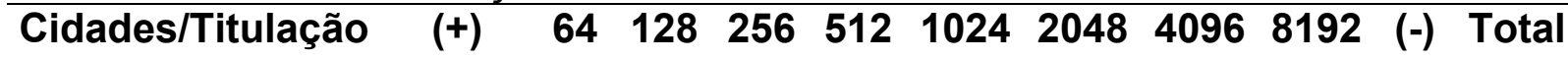

\begin{tabular}{lccccccccccc}
\hline Pedreira & 2 & 1 & 1 & - & - & - & - & - & - & 12 & 14 \\
Piracicaba & 6 & - & 1 & 3 & - & 1 & - & 1 & - & 11 & 17 \\
São Paulo & 6 & 3 & 2 & 1 & - & - & - & - & - & 29 & 35 \\
Pirassununga & 1 & - & - & 1 & - & - & - & - & - & 11 & 12 \\
Mogi das Cruzes & 0 & - & - & - & - & - & - & - & - & 16 & 16 \\
\hline Total & $\mathbf{1 5}$ & $\mathbf{4}$ & $\mathbf{4}$ & $\mathbf{5}$ & - & $\mathbf{1}$ & - & $\mathbf{1}$ & - & $\mathbf{7 9}$ & $\mathbf{9 4}$ \\
\hline
\end{tabular}




\section{APÊNDICE B}

Títulos de anticorpos anti-Rickettsia rickettsii em cães do Estado de São Paulo, verificados através da reação de imunofluorescência indireta

\begin{tabular}{llllllllllllll}
\hline Cidades/Titulação & $(+)$ & 64 & 128 & 256 & 512 & 1024 & 2048 & 4096 & 8192 & $(-)$ & Total
\end{tabular}

\begin{tabular}{lccccccccccc}
\hline Pedreira* $^{*}$ & 11 & 1 & 1 & 2 & 2 & 0 & 2 & 1 & 0 & 8 & 19 \\
Piracicaba & 3 & 3 & 0 & 0 & 0 & 0 & 0 & 0 & 0 & 4 & 7 \\
São Paulo & 3 & 0 & 3 & 0 & 0 & 0 & 0 & 0 & 0 & 8 & 11 \\
Pirassununga & 1 & 1 & 0 & 0 & 0 & 0 & 0 & 0 & 0 & 4 & 5 \\
Mogi das Cruzes & 9 & 1 & 3 & 2 & 0 & 0 & 2 & 1 & 0 & 4 & 13 \\
\hline Total & $\mathbf{2 7}$ & $\mathbf{6}$ & $\mathbf{7}$ & $\mathbf{4}$ & $\mathbf{2}$ & $\mathbf{0}$ & $\mathbf{4}$ & $\mathbf{2}$ & $\mathbf{0}$ & $\mathbf{2 8}$ & $\mathbf{5 5}$
\end{tabular}

* (2) 16.384

Títulos de anticorpos anti-Rickettsia parkeri em cães do Estado de São Paulo, verificados através da reação de imunofluorescência indireta

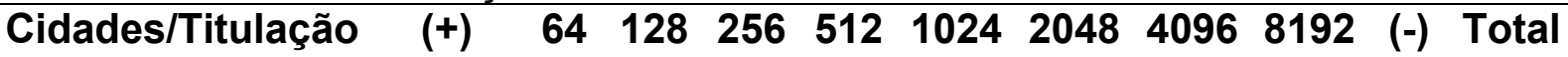

\begin{tabular}{lccccccccccc}
\hline Pedreira & 12 & 2 & 0 & 5 & 1 & 2 & 0 & 0 & 1 & 7 & 19 \\
Piracicaba & 3 & 1 & 0 & 2 & 0 & 0 & 0 & 0 & 0 & 4 & 7 \\
São Paulo & 3 & 1 & 2 & 0 & 0 & 0 & 0 & 0 & 0 & 8 & 11 \\
Pirassununga & 0 & 0 & 0 & 0 & 0 & 0 & 0 & 0 & 0 & 5 & 5 \\
Mogi das Cruzes & 9 & 4 & 1 & 1 & 1 & 0 & 2 & 0 & 0 & 4 & 13 \\
\hline Total & $\mathbf{2 7}$ & $\mathbf{8}$ & $\mathbf{3}$ & $\mathbf{8}$ & $\mathbf{2}$ & $\mathbf{2}$ & $\mathbf{2}$ & $\mathbf{0}$ & $\mathbf{1}$ & $\mathbf{2 8}$ & $\mathbf{5 5}$ \\
\hline
\end{tabular}

* (1) 32768

Títulos de anticorpos anti-Rickettsia felis em cães do Estado de São Paulo, verificados através da reação de imunofluorescência indireta

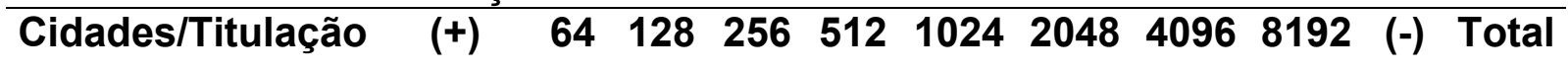

\begin{tabular}{lccccccccccc}
\hline Pedreira & 13 & 3 & 4 & 2 & 1 & 2 & 0 & 1 & 0 & 6 & 19 \\
Piracicaba & 2 & 1 & 1 & 0 & 0 & 0 & 0 & 0 & 0 & 5 & 7 \\
São Paulo & 3 & 3 & 0 & 0 & 0 & 0 & 0 & 0 & 0 & 8 & 11 \\
Pirassununga & 0 & 0 & 0 & 0 & 0 & 0 & 0 & 0 & 0 & 5 & 5 \\
Mogi das Cruzes & 8 & 6 & 0 & 0 & 1 & 1 & 0 & 0 & 0 & 5 & 13 \\
\hline Total & $\mathbf{2 6}$ & $\mathbf{1 3}$ & $\mathbf{5}$ & $\mathbf{2}$ & $\mathbf{2}$ & $\mathbf{3}$ & $\mathbf{0}$ & $\mathbf{1}$ & $\mathbf{0}$ & $\mathbf{2 9}$ & $\mathbf{5 5}$ \\
\hline
\end{tabular}

Títulos de anticorpos anti-Rickettsia bellii em cães do Estado de São Paulo, verificados através da reação de imunofluorescência indireta

\begin{tabular}{lcccccccccccc}
\hline Cidades/Titulação & $\mathbf{( + )}$ & $\mathbf{6 4}$ & $\mathbf{1 2 8}$ & $\mathbf{2 5 6}$ & $\mathbf{5 1 2}$ & $\mathbf{1 0 2 4}$ & $\mathbf{2 0 4 8}$ & $\mathbf{4 0 9 6}$ & $\mathbf{8 1 9 2}$ & $\mathbf{( - )}$ & Total \\
\hline Pedreira & 7 & 3 & 2 & 1 & 0 & 1 & 0 & 0 & 0 & 12 & 19 \\
Piracicaba & 1 & 0 & 1 & 0 & 0 & 0 & 0 & 0 & 0 & 6 & 7 \\
São Paulo & 0 & 0 & 0 & 0 & 0 & 0 & 0 & 0 & 0 & 11 & 11 \\
Pirassununga & 0 & 0 & 0 & 0 & 0 & 0 & 0 & 0 & 0 & 5 & 5 \\
Mogi das Cruzes & 5 & 1 & 2 & 0 & 1 & 1 & 0 & 0 & 0 & 8 & 13 \\
\hline Total & $\mathbf{1 3}$ & $\mathbf{4}$ & $\mathbf{5}$ & $\mathbf{1}$ & $\mathbf{1}$ & $\mathbf{2}$ & $\mathbf{0}$ & $\mathbf{0}$ & $\mathbf{0}$ & $\mathbf{4 2}$ & $\mathbf{5 5}$ \\
\hline
\end{tabular}




\section{APÊNDICE C}

Títulos de anticorpos anti-Rickettsia rickettsii em gatos do Estado de São Paulo, verificados através da reação de imunofluorescência indireta

Cidades/Titulação $\quad(+) \quad 64 \quad 12825651210242048 \quad 40968192$ (-) Total

\begin{tabular}{lccccccccccc}
\hline Pedreira & 3 & - & - & - & 2 & - & 1 & - & - & 0 & 3 \\
Piracicaba & 7 & 2 & 3 & - & 2 & - & - & - & - & 0 & 7 \\
São Paulo & 3 & 1 & 1 & 1 & - & - & - & - & - & 3 & 6 \\
Pirassununga & 3 & - & - & 2 & - & 1 & - & - & - & 3 & 6 \\
Mogi das Cruzes & 3 & - & 1 & - & 1 & - & 1 & - & - & 0 & 3 \\
\hline Total & $\mathbf{1 9}$ & $\mathbf{3}$ & $\mathbf{5}$ & $\mathbf{3}$ & $\mathbf{5}$ & $\mathbf{1}$ & $\mathbf{2}$ & - & - & $\mathbf{6}$ & $\mathbf{2 5}$ \\
\hline
\end{tabular}

Títulos de anticorpos anti-Rickettsia parkeri em gatos do Estado de São Paulo, verificados através da reação de imunofluorescência indireta

Cidades/Titulação $\quad(+) \quad 64128256512102420484096 \quad 8192$ (-) Total

\begin{tabular}{lccccccccccc}
\hline Pedreira & 3 & - & - & 1 & 1 & - & 1 & - & - & 0 & 3 \\
Piracicaba & 6 & 1 & 2 & 1 & 2 & - & - & - & - & 1 & 7 \\
São Paulo & 3 & 1 & 2 & - & - & - & - & - & - & 3 & 6 \\
Pirassununga & 4 & - & 1 & 2 & - & - & 1 & - & - & 2 & 6 \\
Mogi das Cruzes & 3 & - & 1 & 1 & - & - & 1 & - & - & 0 & 3 \\
\hline Total & $\mathbf{1 9}$ & $\mathbf{2}$ & $\mathbf{6}$ & $\mathbf{5}$ & $\mathbf{3}$ & - & $\mathbf{3}$ & - & - & $\mathbf{6}$ & $\mathbf{2 5}$ \\
\hline
\end{tabular}

Títulos de anticorpos anti-Rickettsia felis em gatos do Estado de São Paulo, verificados através da reação de imunofluorescência indireta

Cidades/Titulação $\quad(+) \quad 641282565121024204840968192$ (-) Total

\begin{tabular}{lccccccccccc}
\hline Pedreira & 3 & 2 & 1 & - & - & - & - & - & - & 0 & 3 \\
Piracicaba & 6 & 3 & 2 & 1 & - & - & - & - & - & 1 & 7 \\
São Paulo & 2 & 2 & - & - & - & - & - & - & - & 4 & 6 \\
Pirassununga & 2 & - & 1 & 1 & - & - & - & - & - & 4 & 6 \\
Mogi das Cruzes & 3 & 2 & 1 & - & - & - & - & - & - & 0 & 3 \\
\hline Total & $\mathbf{1 6}$ & $\mathbf{9}$ & $\mathbf{5}$ & $\mathbf{2}$ & - & - & - & - & - & $\mathbf{9}$ & $\mathbf{2 5}$ \\
\hline
\end{tabular}

Títulos de anticorpos anti-Rickettsia bellii em gatos do Estado de São Paulo, verificados através da reação de imunofluorescência indireta

Cidades/Titulação $\quad(+) \quad 64128256512102420484096 \quad 8192$ (-) Total

\begin{tabular}{lccccccccccc}
\hline Pedreira & 2 & - & - & 1 & 1 & - & - & - & - & 1 & 3 \\
Piracicaba & 4 & - & 2 & 2 & - & - & - & - & - & 3 & 7 \\
São Paulo & 0 & - & - & - & - & - & - & - & - & 6 & 6 \\
Pirassununga & 3 & - & 2 & - & - & 1 & - & - & - & 3 & 6 \\
Mogi das Cruzes & 2 & 1 & - & 1 & - & - & - & - & - & 1 & 3 \\
\hline Total & $\mathbf{1 1}$ & $\mathbf{1}$ & $\mathbf{4}$ & $\mathbf{4}$ & $\mathbf{1}$ & $\mathbf{1}$ & - & - & - & 14 & $\mathbf{2 5}$ \\
\hline
\end{tabular}




\section{APÊNDICE D}

Títulos de anticorpos anti-Rickettsia rickettsii em eqüinos do Estado de São Paulo, verificados através da reação de imunofluorescência indireta

Cidades/Titulação $\quad(+) \quad 641282565121024204840968192 \quad(-)$ Total

\begin{tabular}{lccccccccccc}
\hline Pedreira & 18 & 0 & 1 & 0 & 2 & 8 & 3 & 3 & 1 & 2 & 20 \\
Piracicaba & 17 & 2 & 2 & 1 & 3 & 5 & 0 & 2 & 2 & 4 & 21 \\
São Paulo & 7 & 4 & 0 & 0 & 1 & 2 & 0 & 0 & 0 & 13 & 20 \\
Pirassununga & 4 & 0 & 0 & 2 & 1 & 1 & 0 & 0 & 0 & 15 & 19 \\
Mogi das Cruzes & 2 & 1 & 1 & 0 & 0 & 0 & 0 & 0 & 0 & 3 & 5 \\
\hline Total & $\mathbf{4 8}$ & $\mathbf{7}$ & $\mathbf{4}$ & $\mathbf{3}$ & $\mathbf{7}$ & $\mathbf{1 6}$ & $\mathbf{3}$ & $\mathbf{5}$ & $\mathbf{3}$ & $\mathbf{3 7}$ & $\mathbf{8 5}$ \\
\hline
\end{tabular}

Títulos de anticorpos anti-Rickettsia parkeri em eqüinos do Estado de São Paulo, verificados através da reação de imunofluorescência indireta

\begin{tabular}{lccccccccccc}
\hline Cidades/Titulação & $(+)$ & 64 & 128 & 256 & 512 & 1024 & 2048 & 4096 & 8192 & $(-)$ & Total \\
\hline Pedreira & 18 & 1 & 1 & 0 & 5 & 3 & 4 & 3 & 1 & 2 & 20 \\
Piracicaba & 17 & 0 & 5 & 3 & 0 & 1 & 3 & 5 & 0 & 4 & 21 \\
São Paulo & 7 & 2 & 1 & 1 & 1 & 2 & 0 & 0 & 0 & 13 & 20 \\
Pirassununga & 4 & 0 & 1 & 2 & 1 & 0 & 0 & 0 & 0 & 15 & 19 \\
Mogi das Cruzes & 2 & 0 & 2 & 0 & 0 & 0 & 0 & 0 & 0 & 3 & 5 \\
\hline Total & $\mathbf{4 8}$ & $\mathbf{3}$ & $\mathbf{1 0}$ & $\mathbf{6}$ & $\mathbf{7}$ & $\mathbf{6}$ & $\mathbf{7}$ & $\mathbf{8}$ & $\mathbf{1}$ & $\mathbf{3 7}$ & $\mathbf{8 5}$ \\
\hline
\end{tabular}

Títulos de anticorpos anti-Rickettsia felis em eqüinos do Estado de São Paulo, verificados através da reação de imunofluorescência indireta

Cidades/Titulação $\quad(+) \quad 641282565121024204840968192$ (-) Total

\begin{tabular}{lccccccccccc}
\hline Pedreira & 19 & 1 & 2 & 8 & 4 & 3 & 1 & 0 & 0 & 1 & 20 \\
Piracicaba & 17 & 3 & 4 & 0 & 3 & 2 & 4 & 0 & 1 & 4 & 21 \\
São Paulo & 7 & 2 & 3 & 1 & 1 & 0 & 0 & 0 & 0 & 13 & 20 \\
Pirassununga & 4 & 0 & 1 & 2 & 1 & 0 & 0 & 0 & 0 & 15 & 19 \\
Mogi das Cruzes & 2 & 0 & 1 & 1 & 0 & 0 & 0 & 0 & 0 & 3 & 5 \\
\hline Total & $\mathbf{4 9}$ & $\mathbf{6}$ & $\mathbf{1 1}$ & $\mathbf{1 2}$ & $\mathbf{9}$ & $\mathbf{5}$ & $\mathbf{5}$ & $\mathbf{0}$ & $\mathbf{1}$ & $\mathbf{3 6}$ & $\mathbf{8 5}$ \\
\hline
\end{tabular}

Títulos de anticorpos anti-Rickettsia bellii em eqüinos do Estado de São Paulo, verificados através da reação de imunofluorescência indireta

Cidades/Titulação $(+) \quad 641282565121024204840968192 \quad(-)$ Total

\begin{tabular}{lccccccccccc}
\hline Pedreira & 19 & 2 & 6 & 8 & 3 & 0 & 0 & 0 & 0 & 1 & 20 \\
Piracicaba & 19 & 6 & 3 & 3 & 4 & 2 & 0 & 0 & 1 & 2 & 21 \\
São Paulo & 11 & 6 & 2 & 3 & 0 & 0 & 0 & 0 & 0 & 9 & 20 \\
Pirassununga & 10 & 7 & 2 & 0 & 1 & 0 & 0 & 0 & 0 & 9 & 19 \\
Mogi das Cruzes & 3 & 3 & 0 & 0 & 0 & 0 & 0 & 0 & 0 & 2 & 5 \\
\hline Total & $\mathbf{6 2}$ & $\mathbf{2 4}$ & $\mathbf{1 3}$ & $\mathbf{1 4}$ & $\mathbf{8}$ & $\mathbf{2}$ & $\mathbf{0}$ & $\mathbf{0}$ & $\mathbf{1}$ & $\mathbf{2 3}$ & $\mathbf{8 5}$ \\
\hline
\end{tabular}




\section{APÊNDICE E}

Títulos de anticorpos anti-Rickettsia rickettsii em humanos do Estado de São Paulo, verificados através da reação de imunofluorescência indireta

Cidades/Titulação $(+) \quad 64128256512102420484096 \quad 8192 \quad(-)$ Total

\begin{tabular}{lccccccccccc}
\hline Pedreira & 8 & 0 & 4 & 1 & 2 & 1 & 0 & 0 & 0 & 43 & 51 \\
Piracicaba & 7 & 1 & 4 & 1 & 1 & 0 & 0 & 0 & 0 & 62 & 69 \\
São Paulo & 10 & 3 & 4 & 3 & 0 & 0 & 0 & 0 & 0 & 58 & 68 \\
Pirassununga & 5 & 1 & 2 & 1 & 1 & 0 & 0 & 0 & 0 & 23 & 28 \\
Mogi das Cruzes & 4 & 2 & 0 & 1 & 1 & 0 & 0 & 0 & 0 & 17 & 21 \\
\hline Total & $\mathbf{3 4}$ & $\mathbf{7}$ & $\mathbf{1 4}$ & $\mathbf{7}$ & $\mathbf{5}$ & $\mathbf{1}$ & $\mathbf{0}$ & $\mathbf{0}$ & $\mathbf{0}$ & $\mathbf{2 0 4}$ & $\mathbf{2 3 8}$ \\
\hline
\end{tabular}

Títulos de anticorpos anti-Rickettsia parkeri em humanos do Estado de São Paulo, verificados através da reação de imunofluorescência indireta

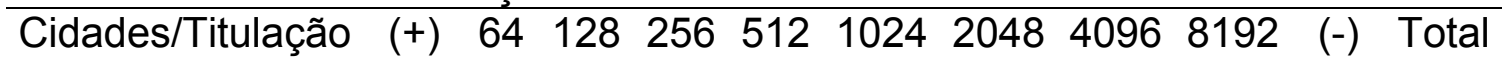

\begin{tabular}{lccccccccccc}
\hline Pedreira & 8 & 2 & 3 & 2 & 1 & 0 & 0 & 0 & 0 & 43 & 51 \\
Piracicaba & 5 & 1 & 4 & 0 & 0 & 0 & 0 & 0 & 0 & 64 & 69 \\
São Paulo & 10 & 1 & 7 & 1 & 1 & 0 & 0 & 0 & 0 & 58 & 68 \\
Pirassununga & 5 & 1 & 1 & 2 & 0 & 1 & 0 & 0 & 0 & 23 & 28 \\
Mogi das Cruzes & 4 & 1 & 0 & 2 & 1 & 0 & 0 & 0 & 0 & 17 & 21 \\
\hline Total & $\mathbf{3 2}$ & $\mathbf{6}$ & $\mathbf{1 5}$ & $\mathbf{7}$ & $\mathbf{3}$ & $\mathbf{1}$ & $\mathbf{0}$ & $\mathbf{0}$ & $\mathbf{0}$ & $\mathbf{2 0 6}$ & $\mathbf{2 3 8}$ \\
\hline
\end{tabular}

Títulos de anticorpos anti-Rickettsia felis em humanos do Estado de São Paulo, verificados através da reação de imunofluorescência indireta

Cidades/Titulação $\quad(+) 641282565121024204840968192 \quad(-)$ Total

\begin{tabular}{lccccccccccc}
\hline Pedreira & 8 & 5 & 0 & 2 & 1 & 0 & 0 & 0 & 0 & 43 & 51 \\
Piracicaba & 5 & 3 & 0 & 2 & 0 & 0 & 0 & 0 & 0 & 64 & 69 \\
São Paulo & 6 & 0 & 0 & 4 & 2 & 0 & 0 & 0 & 0 & 62 & 68 \\
Pirassununga & 5 & 5 & 0 & 0 & 0 & 0 & 0 & 0 & 0 & 23 & 28 \\
Mogi das Cruzes & 4 & 1 & 2 & 0 & 1 & 0 & 0 & 0 & 0 & 17 & 21 \\
\hline Total & $\mathbf{2 8}$ & $\mathbf{1 4}$ & $\mathbf{2}$ & $\mathbf{8}$ & $\mathbf{4}$ & $\mathbf{0}$ & $\mathbf{0}$ & $\mathbf{0}$ & $\mathbf{0}$ & $\mathbf{2 1 0}$ & $\mathbf{2 3 8}$ \\
\hline
\end{tabular}

Títulos de anticorpos anti-Rickettsia bellii em humanos do Estado de São Paulo, verificados através da reação de imunofluorescência indireta

Cidades/Titulação $\quad(+) \quad 641282565121024204840968192$ (-) Total

\begin{tabular}{lccccccccccc}
\hline Pedreira & 5 & 2 & 1 & 1 & 1 & 0 & 0 & 0 & 0 & 46 & 51 \\
Piracicaba & 6 & 3 & 3 & 0 & 0 & 0 & 0 & 0 & 0 & 63 & 69 \\
São Paulo & 5 & 1 & 3 & 0 & 1 & 0 & 0 & 0 & 0 & 63 & 68 \\
Pirassununga & 3 & 0 & 1 & 1 & 1 & 0 & 0 & 0 & 0 & 25 & 28 \\
Mogi das Cruzes & 4 & 1 & 2 & 1 & 0 & 0 & 0 & 0 & 0 & 17 & 21 \\
\hline Total & $\mathbf{2 3}$ & $\mathbf{7}$ & $\mathbf{1 0}$ & $\mathbf{3}$ & $\mathbf{3}$ & $\mathbf{0}$ & $\mathbf{0}$ & $\mathbf{0}$ & $\mathbf{0}$ & $\mathbf{2 1 5}$ & $\mathbf{2 3 8}$ \\
\hline
\end{tabular}


APÊNDICE F

Amostras de gambás testadas frente à Rickettsia spp, oriundos do Estado de São Paulo, 2006

(continua)

\begin{tabular}{|c|c|c|c|c|c|c|c|c|c|c|c|c|}
\hline \multirow{2}{*}{ Cidade } & \multirow{2}{*}{ Gambá } & \multicolumn{4}{|c|}{ RIFI $^{1}$} & \multirow{2}{*}{$\mathbf{P C R}^{2}$} & \multicolumn{3}{|c|}{ Pulgas } & \multicolumn{3}{|c|}{ Carrapatos } \\
\hline & & R. rickettsii & R. parkeri & R. felis & R. bellii & & $\mathrm{n}^{3}$ & $\mathbf{p}^{4}$ & Rickettsia & $\mathrm{n}^{3}$ & $p^{4}$ & Rickettsia \\
\hline \multirow{13}{*}{ Pedreira } & G49 & 2048 & 256 & 128 & - & - & 11 & 0 & - & 28 & 0 & - \\
\hline & G50 & 1024 & 1024 & - & - & - & 11 & 0 & - & 8 & 1 & R. bellii \\
\hline & G68 & 64 & 256 & 64 & - & - & 1 & 0 & - & 0 & 0 & - \\
\hline & G89 & - & - & 64 & - & - & 4 & 0 & - & 0 & 0 & - \\
\hline & G90 & - & - & - & - & - & 7 & 4 & R. felis & 0 & 0 & - \\
\hline & G91 & 256 & - & 128 & 64 & - & 1 & 1 & R. felis & 0 & 0 & - \\
\hline & G92 & 64 & 128 & 64 & - & - & 2 & 0 & - & 0 & 0 & - \\
\hline & G93 & 2048 & 512 & 64 & - & - & 3 & 2 & R. felis & 0 & 0 & - \\
\hline & G94 & 256 & 128 & 64 & 128 & - & 5 & 5 & R. felis & 0 & 0 & - \\
\hline & G95 & 128 & 64 & 64 & - & - & 0 & 0 & - & 1 & 0 & - \\
\hline & G96 & 512 & 64 & 128 & - & - & 1 & 1 & R. felis & 0 & 0 & - \\
\hline & G97 & 512 & 512 & - & - & - & 10 & 6 & R. felis & 0 & 0 & - \\
\hline & G99 & 128 & 128 & - & - & - & 1 & 0 & - & 0 & 0 & - \\
\hline \multirow[t]{14}{*}{ Piracicaba } & G3 & 64 & 64 & - & - & - & 0 & 0 & - & 41 & 0 & - \\
\hline & G5 & 512 & 256 & 64 & - & - & 0 & 0 & - & 79 & 0 & - \\
\hline & G29 & 512 & 128 & 64 & - & - & 0 & 0 & - & 1 & 0 & - \\
\hline & G30 & 32768 & 4096 & 2048 & 4096 & - & 4 & 0 & - & 7 & 0 & - \\
\hline & G31 & 64 & 128 & 64 & - & - & 0 & 0 & - & 22 & 1 & R. bellii \\
\hline & G32 & - & - & - & - & - & 0 & 0 & - & 1 & 0 & - \\
\hline & G33 & 4096 & 512 & 512 & 1024 & - & 5 & 0 & - & 122 & 2 & R. bellii \\
\hline & G53 & 256 & 128 & - & - & - & 6 & 3 & R. felis & 8 & 1 & Rickettsia $\mathrm{sp}$ \\
\hline & G54 & - & - & - & - & - & 4 & 4 & R. felis & 0 & 0 & - \\
\hline & G55 & 512 & 128 & 128 & 128 & - & 0 & 0 & - & 9 & 0 & - \\
\hline & G65 & - & - & - & - & - & 0 & 0 & - & 5 & 0 & - \\
\hline & G66 & - & - & - & - & - & 1 & 0 & - & 0 & 0 & - \\
\hline & G67 & 1024 & 512 & 128 & 256 & - & 0 & 0 & - & 0 & 0 & - \\
\hline & G76 & 8192 & 4096 & 256 & 256 & - & 3 & 1 & R. felis & 148 & 2 & $\begin{array}{c}\text { R. bellii } \\
\text { R. }\end{array}$ \\
\hline
\end{tabular}




\section{APÊNDICE F}

Amostras de gambás testadas frente à Rickettsia spp, oriundos do Estado de São Paulo, 2006 (continuação)

\begin{tabular}{|c|c|c|c|c|c|c|c|c|c|c|c|c|}
\hline \multirow{2}{*}{ Cidade } & \multirow{2}{*}{ Gambá } & \multicolumn{4}{|c|}{ RIFI $^{1}$} & \multirow{2}{*}{$\mathrm{PCR}^{2}$} & \multicolumn{3}{|c|}{ Pulgas } & \multicolumn{3}{|c|}{ Carrapatos } \\
\hline & & R. rickettsii & R. parkeri & R. felis & R. bellii & & $\mathrm{n}^{3}$ & $p^{4}$ & Rickettsia & $\mathrm{n}^{3}$ & $p^{4}$ & Rickettsia \\
\hline \multirow[t]{3}{*}{ Piracicaba } & G77 & - & - & 64 & - & - & 1 & 0 & - & 3 & 0 & - \\
\hline & G78 & 256 & 256 & 256 & 256 & - & 0 & 0 & - & 29 & 1 & Rickettsia $\mathrm{sp}$ \\
\hline & G79 & - & 128 & 64 & - & - & 0 & 0 & - & 4 & 0 & - \\
\hline \multirow[t]{23}{*}{ São Paulo } & G1 & 1024 & 512 & - & - & - & 0 & 0 & - & 0 & 0 & - \\
\hline & $\mathrm{G} 2$ & 1024 & 1024 & - & - & - & 0 & 0 & - & 0 & 0 & - \\
\hline & G4 & 256 & 512 & - & 256 & - & 0 & 0 & - & 0 & 0 & - \\
\hline & G7 & - & 128 & 128 & 64 & - & 0 & 0 & - & 0 & 0 & - \\
\hline & G8 & 512 & 256 & 128 & - & - & 0 & 0 & - & 0 & 0 & - \\
\hline & G9 & 128 & 64 & - & - & - & 0 & 0 & - & 0 & 0 & - \\
\hline & G10 & - & - & - & - & - & 5 & 2 & R. felis & 0 & 0 & - \\
\hline & G11 & 1024 & 512 & 256 & - & - & 0 & 0 & - & 0 & 0 & - \\
\hline & G13 & - & - & - & - & - & 0 & 0 & - & 1 & 1 & R. bellii \\
\hline & G14 & - & - & - & - & - & 0 & 0 & - & 1 & 1 & R. bellii \\
\hline & G16 & 128 & 128 & - & - & - & 0 & 0 & - & 0 & 0 & - \\
\hline & G17 & - & - & - & - & - & 1 & 1 & R. felis & 0 & 0 & - \\
\hline & G18 & - & - & - & - & - & 1 & 0 & - & 1 & 1 & R. bellii \\
\hline & G19 & 128 & 128 & - & - & - & 1 & 0 & - & 3 & 3 & R. bellii \\
\hline & G20 & 64 & 128 & - & - & - & 0 & 0 & - & 0 & 0 & - \\
\hline & $\mathrm{G} 21$ & 128 & 64 & - & - & - & 0 & 0 & - & 0 & 0 & - \\
\hline & G26 & - & - & - & 64 & - & 4 & 2 & R. felis & 0 & 0 & - \\
\hline & $\mathrm{G} 27$ & 256 & 128 & - & - & - & 1 & 1 & R. felis & 0 & 0 & - \\
\hline & $\mathrm{G} 28$ & - & - & - & - & - & 7 & 6 & R. felis & 0 & 0 & - \\
\hline & G34 & 64 & 128 & - & - & - & 0 & 0 & & 0 & 0 & - \\
\hline & G36 & 1024 & 256 & 256 & - & - & 2 & 0 & & 0 & 0 & - \\
\hline & G37 & 128 & 64 & - & - & - & 4 & 0 & & 0 & 0 & - \\
\hline & G38 & - & - & - & - & - & 21 & 8 & R. felis & 0 & 0 & - \\
\hline
\end{tabular}


APÊNDICE F

Amostras de gambás testadas frente à Rickettsia spp, oriundos do Estado de São Paulo, 2006 (continuação)

\begin{tabular}{|c|c|c|c|c|c|c|c|c|c|c|c|c|}
\hline \multirow{2}{*}{ Cidade } & \multirow{2}{*}{ Gambá } & \multicolumn{4}{|c|}{ RIFI $^{1}$} & \multirow{2}{*}{$\mathbf{P C R}^{2}$} & \multicolumn{3}{|c|}{ Pulgas } & \multicolumn{3}{|c|}{ Carrapatos } \\
\hline & & R. rickettsii & R. parkeri & R. felis & R. bellii & & $n^{3}$ & $p^{4}$ & Rickettsia & $n^{3}$ & $p^{4}$ & Rickettsia \\
\hline \multirow[t]{7}{*}{ São Paulo } & G40 & 512 & 512 & - & 128 & - & 0 & 0 & - & 0 & 0 & - \\
\hline & G41 & - & - & - & 128 & - & 0 & 0 & - & 0 & 0 & - \\
\hline & G45 & 512 & 256 & - & - & - & 7 & 4 & R. felis & 0 & 0 & - \\
\hline & G47 & - & - & - & - & - & 1 & 0 & - & 0 & 0 & - \\
\hline & G51 & 512 & 256 & 128 & 64 & - & 0 & 0 & - & 0 & 0 & - \\
\hline & G52 & 128 & 128 & 128 & - & - & 4 & 2 & R. felis & 0 & 0 & - \\
\hline & G88 & - & - & - & - & - & 1 & 1 & R. felis & 0 & 0 & - \\
\hline \multirow{12}{*}{ Pirassununga } & G42 & 128 & 256 & - & - & - & 3 & 0 & - & 4 & 1 & R. bellii \\
\hline & G43 & 256 & 256 & - & - & - & 4 & 0 & - & 0 & 0 & - \\
\hline & G44 & 128 & 128 & - & 256 & - & 14 & 0 & - & 3 & 0 & - \\
\hline & G46 & 256 & 1024 & 256 & - & - & 2 & 0 & - & 3 & 1 & R. bellii \\
\hline & G80 & - & - & 64 & - & - & 2 & 1 & R. felis & 5 & 1 & R. bellii \\
\hline & G81 & - & - & - & - & - & 5 & 0 & - & 2 & 1 & R. bellii \\
\hline & G82 & - & - & - & - & - & 9 & 2 & R. felis & 2 & 1 & R. bellii \\
\hline & G83 & - & - & - & - & - & 7 & 0 & - & 1 & 1 & R. felis \\
\hline & G84 & 64 & 128 & - & - & - & 11 & 0 & - & 52 & $\begin{array}{c}13 \\
2\end{array}$ & $\begin{array}{l}\text { R. bellii } \\
\text { R. felis }\end{array}$ \\
\hline & G85 & - & - & - & - & - & 4 & 0 & - & 3 & $\begin{array}{l}1 \\
2\end{array}$ & $\begin{array}{l}\text { R. bellii } \\
\text { R. felis }\end{array}$ \\
\hline & G86 & 128 & 128 & 64 & - & - & 2 & 0 & - & 2 & 2 & R. bellii \\
\hline & G87 & - & - & 64 & - & - & 0 & 0 & - & 1 & 0 & - \\
\hline \multirow[t]{7}{*}{ Mogi das Cruzes } & G56 & 2048 & 256 & 512 & - & - & 7 & 0 & - & 8 & 3 & R. bellii \\
\hline & G57 & 512 & 512 & - & - & - & 7 & 0 & - & 10 & 5 & R. bellii \\
\hline & G58 & - & - & - & - & - & 9 & 0 & - & 4 & 3 & R. bellii \\
\hline & G59 & - & - & - & - & - & 16 & 6 & R. felis & 9 & 8 & R. bellii \\
\hline & G60 & - & - & - & - & - & 9 & 0 & - & 28 & 8 & R. bellii \\
\hline & G61 & 1024 & 512 & - & - & - & 3 & 0 & - & 1 & 0 & - \\
\hline & G62 & 1024 & 512 & 64 & - & - & 21 & 6 & R. felis & 2 & 1 & R. bellii \\
\hline
\end{tabular}




\section{APÊNDICE F}

Amostras de gambás testadas frente à Rickettsia spp, oriundos do Estado de São Paulo, 2006

(conclusão)

\begin{tabular}{|c|c|c|c|c|c|c|c|c|c|c|c|c|}
\hline \multirow{2}{*}{ Cidade } & \multirow{2}{*}{ Gambá } & \multicolumn{4}{|c|}{ RIFI $^{1}$} & \multirow{2}{*}{$\mathbf{P C R}^{2}$} & \multicolumn{3}{|c|}{ Pulgas } & \multicolumn{3}{|c|}{ Carrapatos } \\
\hline & & R. rickettsii & R. parkeri & R. felis & R. bellii & & $n^{3}$ & $p^{4}$ & Rickettsia & $n^{3}$ & $p^{4}$ & Rickettsia \\
\hline \multirow{10}{*}{ Mogi das Cruzes } & G63 & 64 & - & - & - & - & 9 & 0 & - & 10 & 1 & R. bellii \\
\hline & G64 & 256 & 512 & - & - & - & 3 & 0 & - & 3 & 1 & R. bellii \\
\hline & G69 & - & - & - & - & - & 2 & 0 & - & 2 & 1 & R. bellii \\
\hline & G70 & 256 & 64 & - & - & - & 1 & 0 & - & 2 & 0 & - \\
\hline & G71 & 64 & 256 & - & - & - & 4 & 0 & - & 4 & 2 & R. bellii \\
\hline & G72 & 256 & - & 256 & - & - & 1 & 1 & R. felis & 5 & 2 & R. bellii \\
\hline & G73 & - & - & - & - & - & 12 & 1 & R. bellii & 5 & 2 & R. bellii \\
\hline & G74 & - & - & - & - & - & 3 & 0 & - & 12 & 1 & R. bellii \\
\hline & & & & & & & & & & & 1 & R. felis \\
\hline & G75 & 256 & 256 & - & - & - & 0 & 0 & - & 5 & 1 & R. bellii \\
\hline Total & 88 & 56 & 55 & 33 & 15 & $\mathbf{0}$ & 312 & 71 & 71 & 709 & 81 & 81 \\
\hline
\end{tabular}

1 títulos de anticorpos anti-Rickettsia spp verificados nos soros dos animais testados pela RIFI; ${ }^{2}$ resultado da PCR nas amostras de sangue; ${ }^{3}$ número de ectoparasitos analisados; ${ }^{4}$ indivíduos positivos para Rickettsia spp pela PCR.

Observação: Não constam na tabela, dados de gambás não reagentes pela RIFI e que não apresentavam ectoparasitos: 1 indivíduo de Pedreira e 5 de São Paulo 


\section{APÊNDICE G}

Amostras de cães testadas frente à Rickettsia spp, oriundos do Estado de São Paulo, 2006

(continua)

\begin{tabular}{|c|c|c|c|c|c|c|c|c|c|c|c|c|}
\hline \multirow{2}{*}{ Cidade } & \multirow{2}{*}{ Cão } & \multicolumn{4}{|c|}{ RIFI $^{1}$} & \multirow{2}{*}{$\mathbf{P C R}^{2}$} & \multicolumn{3}{|c|}{ Pulgas } & \multicolumn{3}{|c|}{ Carrapatos } \\
\hline & & R. rickettsii & R. parkeri & R. felis & R. bellii & & $n^{3}$ & $p^{4}$ & Rickettsia & $n^{3}$ & $p^{4}$ & Rickettsia \\
\hline \multirow[t]{19}{*}{ Pedreira } & $\mathrm{C} 1$ & - & - & - & - & - & 1 & 0 & - & 26 & 0 & - \\
\hline & C3 & 256 & 256 & 128 & 256 & - & 5 & 3 & R. felis & 4 & 0 & - \\
\hline & $\mathrm{C} 4$ & - & - & 64 & - & - & 2 & 0 & & 11 & 0 & - \\
\hline & $\mathrm{C} 5$ & - & 64 & 64 & - & - & 3 & 1 & R. felis & 0 & 0 & - \\
\hline & C6 & 256 & 256 & 128 & 64 & - & 0 & 0 & - & 9 & 0 & - \\
\hline & $\mathrm{C} 7$ & - & - & - & - & - & 0 & 0 & - & 8 & 0 & - \\
\hline & $\mathrm{C} 8$ & - & - & - & - & - & 0 & 0 & - & 1 & 0 & - \\
\hline & C9 & - & - & - & - & - & 2 & 1 & R. felis & 9 & 0 & - \\
\hline & $\mathrm{C} 20$ & 64 & 64 & 128 & - & - & 3 & 2 & R. felis & 6 & 0 & - \\
\hline & $\mathrm{C} 21$ & 512 & 256 & 256 & - & - & 1 & 0 & - & 2 & 0 & - \\
\hline & $\mathrm{C} 22$ & 128 & 256 & 64 & - & - & 9 & 4 & R. felis & 1 & 0 & - \\
\hline & $\mathrm{C} 23$ & - & - & - & - & - & 7 & 7 & R. felis & 2 & 0 & - \\
\hline & $\mathrm{C} 24$ & - & - & - & - & - & 2 & 0 & - & 4 & 0 & - \\
\hline & $\mathrm{C} 25$ & 16384 & 8192 & 1024 & - & - & 2 & 1 & R. felis & 3 & 0 & - \\
\hline & $\mathrm{C} 26$ & 16384 & 32768 & 4096 & 1024 & - & 14 & 6 & R. felis & 6 & 0 & - \\
\hline & $\mathrm{C} 27$ & 4096 & 1024 & 1024 & 128 & - & 2 & 0 & - & 1 & 0 & - \\
\hline & $\mathrm{C} 28$ & 512 & 256 & 128 & 64 & - & 9 & 6 & R. felis & 0 & 0 & - \\
\hline & C29 & 2048 & 512 & 256 & 64 & - & 7 & 4 & R. felis & 0 & 0 & - \\
\hline & C30 & 2048 & 1024 & 512 & 128 & - & 5 & 4 & R. felis & 1 & 0 & - \\
\hline \multirow[t]{8}{*}{ Piracicaba } & $\mathrm{C} 15$ & - & - & - & - & - & 1 & 1 & R. felis & 0 & 0 & - \\
\hline & $\mathrm{C} 16$ & - & - & 128 & - & - & 1 & 1 & R. felis & 4 & 0 & - \\
\hline & C51 & 64 & 256 & - & - & - & 0 & 0 & - & 1 & 0 & - \\
\hline & C52 & - & - & 64 & - & - & 0 & 0 & - & 0 & 0 & - \\
\hline & C54 & 64 & 64 & - & - & - & 19 & 5 & R. felis & 0 & 0 & - \\
\hline & C55 & 64 & 256 & - & 128 & - & 25 & 14 & R. felis & 0 & 0 & - \\
\hline & $\mathrm{C} 40$ & 128 & 128 & 64 & - & - & 5 & 3 & R. felis & 0 & 0 & - \\
\hline & C41 & - & - & - & - & - & 3 & 3 & R. felis & 1 & 0 & - \\
\hline
\end{tabular}




\section{APÊNDICE G}

Amostras de cães testadas frente à Rickettsia spp, oriundos do Estado de São Paulo, 2006

(conclusão)

\begin{tabular}{|c|c|c|c|c|c|c|c|c|c|c|c|c|}
\hline \multirow{2}{*}{ Cidade } & \multirow{2}{*}{ Cão } & \multicolumn{4}{|c|}{ RIFI $^{1}$} & \multirow{2}{*}{$\mathbf{P C R}^{2}$} & \multicolumn{3}{|c|}{ Pulgas } & \multicolumn{3}{|c|}{ Carrapatos } \\
\hline & & R. rickettsii & R. parkeri & R. felis & R. belliii & & $n^{3}$ & $\mathbf{p}^{4}$ & Rickettsia & $\mathrm{n}^{3}$ & $p^{4}$ & Rickettsia \\
\hline \multirow[t]{6}{*}{ São Paulo } & $\mathrm{C} 42$ & - & - & - & - & - & 1 & 0 & - & 0 & 0 & - \\
\hline & $\mathrm{C} 44$ & - & - & - & - & - & 3 & 1 & R. felis & 0 & 0 & - \\
\hline & $\mathrm{C} 45$ & - & - & - & - & - & 7 & 2 & R. felis & 0 & 0 & - \\
\hline & $\mathrm{C} 46$ & 128 & 128 & 64 & - & - & 0 & 0 & - & 0 & 0 & - \\
\hline & $\mathrm{C} 48$ & 128 & 64 & - & - & - & 4 & 3 & R. felis & 0 & 0 & - \\
\hline & C49 & - & - & 64 & - & - & 2 & 2 & R. felis & 0 & 0 & - \\
\hline \multirow[t]{3}{*}{ Pirassununga } & $\mathrm{C} 17$ & - & - & - & - & - & 36 & 5 & R. felis & 0 & 0 & - \\
\hline & C19 & - & - & - & - & - & 1 & 0 & - & 0 & 0 & - \\
\hline & $\mathrm{C} 32$ & 64 & - & - & - & - & 0 & 0 & - & 0 & 0 & - \\
\hline \multirow[t]{13}{*}{ Mogi das Cruzes } & $\mathrm{C} 2$ & - & - & - & - & - & 10 & 5 & R. felis & 0 & 0 & - \\
\hline & $\mathrm{C} 10$ & - & - & - & 64 & - & 2 & 0 & - & 0 & 0 & - \\
\hline & $\mathrm{C} 11$ & - & - & - & - & - & 0 & 0 & - & 2 & 0 & - \\
\hline & $\mathrm{C} 12$ & 128 & 64 & 64 & 128 & - & 0 & 0 & - & 0 & 0 & - \\
\hline & $\mathrm{C} 13$ & 128 & 128 & 64 & - & - & 0 & 0 & - & 0 & 0 & - \\
\hline & $\mathrm{C} 14$ & 4096 & 2048 & 1024 & 1024 & - & 2 & 0 & - & 12 & 0 & - \\
\hline & $\mathrm{C} 33$ & 256 & 64 & 64 & - & - & 1 & 0 & - & 0 & 0 & - \\
\hline & C34 & 128 & 64 & 64 & - & - & 3 & 3 & R. felis & 1 & 0 & - \\
\hline & C35 & 256 & 256 & 64 & - & - & 0 & 0 & - & 0 & 0 & - \\
\hline & C36 & 2048 & 512 & - & - & - & 0 & 0 & - & 0 & 0 & - \\
\hline & C37 & 2048 & 2048 & 512 & 512 & - & 0 & 0 & - & 0 & 0 & - \\
\hline & C38 & - & - & - & - & - & 1 & 0 & - & 0 & 0 & - \\
\hline & C39 & 64 & 64 & 64 & 128 & - & 6 & 2 & R. felis & 0 & 0 & - \\
\hline Total & 49 & 27 & 27 & 26 & 13 & 0 & 121 & 89 & - & 115 & 0 & - \\
\hline
\end{tabular}

1 títulos de anticorpos anti-Rickettsia spp verificados nos soros dos animais testados pela RIFI; ${ }^{2}$ resultado da PCR nas amostras de sangue; ${ }^{3}$ número de ectoparasitos analisados; ${ }^{4}$ indivíduos positivos para Rickettsia spp pela PCR.

Observação: Não constam na tabela, dados de cães não reagentes pela RIFI e que não apresentavam ectoparasitos: 1 indivíduo de Piracicaba, 3 de São Paulo e 2 de Pirassununga 


\section{APÊNDICE H}

Amostras de gatos testadas frente à Rickettsia spp, oriundos do Estado de São Paulo, 2006

\begin{tabular}{|c|c|c|c|c|c|c|c|c|c|c|c|c|}
\hline \multirow{2}{*}{ Cidade } & \multirow{2}{*}{ Gato } & \multicolumn{4}{|c|}{ RIFI $^{1}$} & \multirow{2}{*}{$\mathbf{P C R}^{2}$} & \multicolumn{3}{|c|}{ Pulgas } & \multicolumn{3}{|c|}{ Carrapatos } \\
\hline & & R. rickettsii & R. parkeri & R. felis & R. bellii & & $n^{3}$ & $p^{4}$ & Rickettsia & $n^{3}$ & $p^{4}$ & Rickettsia \\
\hline \multirow[t]{3}{*}{ Pedreira } & Ga1 & 2048 & 2048 & 128 & 512 & - & 4 & 3 & R. felis & 1 & 0 & - \\
\hline & $\mathrm{Ga} 2$ & 512 & 512 & 64 & 256 & - & 0 & 0 & - & 0 & 0 & - \\
\hline & $\mathrm{Ga} 20$ & 512 & 256 & 64 & - & - & 3 & 2 & R. felis & 3 & 0 & - \\
\hline \multirow[t]{7}{*}{ Piracicaba } & Ga6 & 64 & 128 & 64 & 128 & - & 1 & 0 & - & 2 & 0 & - \\
\hline & $\mathrm{Ga} 7$ & 64 & 64 & - & - & - & 1 & 1 & R. felis & 0 & 0 & - \\
\hline & $\mathrm{Ga} 8$ & 128 & - & 256 & - & - & 1 & 1 & R. felis & 0 & 0 & - \\
\hline & Ga9 & 512 & 512 & 64 & 256 & - & 2 & 1 & R. felis & 0 & 0 & - \\
\hline & Ga10 & 128 & 256 & 64 & - & - & 0 & 0 & - & 0 & 0 & - \\
\hline & Ga11 & 512 & 512 & 128 & 256 & - & 2 & 0 & - & 1 & 0 & - \\
\hline & Ga12 & 128 & 128 & 128 & 128 & - & 0 & 0 & - & 2 & 0 & - \\
\hline \multirow[t]{6}{*}{ São Paulo } & Ga14 & - & - & 64 & - & - & 8 & 4 & R. felis & 0 & 0 & - \\
\hline & Ga21 & 64 & 64 & - & - & - & 2 & 0 & - & 0 & 0 & - \\
\hline & $\mathrm{Ga} 22$ & 256 & 128 & - & - & - & 6 & 1 & R. felis & 0 & 0 & - \\
\hline & Ga23 & - & - & - & - & - & 1 & 0 & - & 0 & 0 & - \\
\hline & $\mathrm{Ga} 24$ & 128 & 128 & 64 & - & - & 0 & 0 & - & 0 & 0 & - \\
\hline & $\mathrm{Ga} 25$ & - & - & - & - & - & 0 & 0 & - & 0 & 0 & - \\
\hline \multirow[t]{6}{*}{ Pirassununga } & Ga13 & - & 128 & 256 & - & - & 1 & 0 & R. felis & 0 & 0 & - \\
\hline & Ga15 & 256 & 256 & - & 128 & - & 16 & 5 & R. felis & 0 & 0 & - \\
\hline & Ga16 & - & - & - & - & - & 3 & 0 & - & 0 & 0 & - \\
\hline & Ga17 & 1024 & 2048 & 128 & 1024 & - & 0 & 0 & - & 0 & 0 & - \\
\hline & Ga18 & - & - & - & - & - & 9 & 4 & R. felis & 0 & 0 & - \\
\hline & Ga19 & 256 & 256 & - & 128 & - & 0 & 0 & - & 0 & 0 & - \\
\hline \multirow[t]{3}{*}{ Mogi das Cruzes } & $\mathrm{Ga} 3$ & 128 & 128 & 64 & - & - & 5 & 3 & R. felis & 0 & 0 & - \\
\hline & $\mathrm{Ga} 4$ & 512 & 256 & 128 & 64 & - & 0 & 0 & - & 1 & 0 & - \\
\hline & Ga5 & 2048 & 2048 & 64 & 256 & - & 1 & 0 & - & 0 & 0 & - \\
\hline Total & 25 & 19 & 19 & 16 & 11 & $\mathbf{0}$ & 66 & 25 & 25 & 10 & $\mathbf{0}$ & - \\
\hline
\end{tabular}

${ }^{1}$ títulos de anticorpos anti-Rickettsia spp verificados nos soros dos animais testados pela RIFI; ${ }^{2}$ resultado da PCR nas amostras de sangue; ${ }^{3}$ número de ectoparasitos analisados; ${ }^{4}$ indivíduos positivos para Rickettsia spp pela PCR 
APÊNDICE I

Amostras de eqüinos testadas frente à Rickettsia spp, oriundos do Estado de São Paulo, 2006

(continua)

\begin{tabular}{|c|c|c|c|c|c|c|}
\hline \multirow{2}{*}{ Cidade } & \multirow{2}{*}{ Eqüino } & \multicolumn{4}{|c|}{ RIFI $^{1}$} & \multirow{2}{*}{$\mathbf{P C R}^{2}$} \\
\hline & & R. rickettsii & R. parkeri & R. felis & R. bellii & \\
\hline \multirow[t]{19}{*}{ Pedreira } & E44 & 1024 & 1024 & 512 & 128 & - \\
\hline & E46 & 512 & 512 & 256 & 128 & - \\
\hline & E47 & - & - & 128 & 64 & - \\
\hline & E48 & 512 & 128 & 256 & 256 & - \\
\hline & E49 & 128 & 64 & 64 & 64 & - \\
\hline & E50 & 2048 & 2048 & 256 & 256 & - \\
\hline & E51 & 4096 & 4096 & 1024 & 256 & - \\
\hline & E52 & 8192 & 8192 & 512 & 512 & - \\
\hline & E53 & 4096 & 2048 & 2048 & 256 & - \\
\hline & E54 & 1024 & 2048 & 256 & 256 & - \\
\hline & E55 & 1024 & 512 & 256 & 128 & - \\
\hline & E56 & 1024 & 512 & 256 & 128 & - \\
\hline & E57 & 2048 & 2048 & 512 & 256 & - \\
\hline & E58 & 4096 & 4096 & 1024 & 512 & - \\
\hline & E59 & 1024 & 1024 & 256 & 512 & - \\
\hline & E60 & 1024 & 1024 & 512 & 128 & - \\
\hline & E61 & 1024 & 512 & 128 & 128 & - \\
\hline & E62 & 1024 & 512 & 256 & 256 & - \\
\hline & E63 & 2048 & 4096 & 1024 & 256 & - \\
\hline \multirow[t]{6}{*}{ Piracicaba } & E1 & 4096 & 4096 & 1024 & 512 & - \\
\hline & E2 & 128 & 256 & 64 & 64 & - \\
\hline & E3 & 8192 & 4096 & 2048 & 1024 & - \\
\hline & E4 & 1024 & 2048 & 2048 & 512 & - \\
\hline & E5 & 512 & 1024 & 512 & 64 & - \\
\hline & E6 & 1024 & 2048 & 2048 & 512 & - \\
\hline
\end{tabular}




\section{APÊNDICE I}

Amostras de eqüinos testadas frente à Rickettsia spp, oriundos do Estado de São Paulo, 2006 (continuação)

\begin{tabular}{|c|c|c|c|c|c|c|}
\hline \multirow{2}{*}{ Cidade } & \multirow{2}{*}{ Eqüino } & \multicolumn{4}{|c|}{ RIFI $^{1}$} & \multirow{2}{*}{$\mathbf{P C R}^{2}$} \\
\hline & & R. rickettsii & R. parkeri & R. felis & R. bellii & \\
\hline \multirow[t]{13}{*}{ Piracicaba } & E7 & 1024 & 256 & 64 & 256 & - \\
\hline & E8 & 64 & 128 & 128 & 128 & - \\
\hline & E9 & - & - & 64 & 64 & - \\
\hline & E10 & 128 & 128 & 128 & 256 & - \\
\hline & E11 & 256 & 128 & 128 & 128 & - \\
\hline & E12 & 512 & 256 & - & 64 & - \\
\hline & E13 & 8192 & 4096 & 8192 & 8192 & - \\
\hline & E14 & - & - & - & 64 & - \\
\hline & E15 & 64 & 128 & 128 & 128 & - \\
\hline & E16 & 512 & 128 & 1024 & 64 & - \\
\hline & E18 & 1024 & 2048 & 512 & 256 & - \\
\hline & E19 & 4096 & 4096 & 2048 & 1024 & - \\
\hline & E20 & 1024 & 4096 & 512 & 512 & - \\
\hline \multirow[t]{11}{*}{ São Paulo } & E68 & 64 & 64 & 128 & 64 & - \\
\hline & E70 & - & - & - & 64 & - \\
\hline & E71 & - & - & 64 & 64 & - \\
\hline & E72 & 64 & 64 & 128 & 128 & - \\
\hline & E73 & 1024 & 1024 & 128 & 64 & - \\
\hline & E74 & 64 & 256 & 256 & 256 & - \\
\hline & E75 & 1024 & 1024 & 128 & 128 & - \\
\hline & E78 & 512 & 512 & 512 & 256 & - \\
\hline & E80 & 64 & 128 & - & 256 & - \\
\hline & E84 & - & - & - & 64 & - \\
\hline & E85 & - & - & 64 & 64 & - \\
\hline
\end{tabular}




\section{APÊNDICE I}

Amostras de eqüinos testadas frente à Rickettsia spp, oriundos do Estado de São Paulo, 2006

(conclusão)

\begin{tabular}{|c|c|c|c|c|c|c|}
\hline \multirow{2}{*}{ Cidade } & \multirow{2}{*}{ Eqüino } & \multicolumn{4}{|c|}{ RIFI $^{1}$} & \multirow{2}{*}{$\mathbf{P C R}^{2}$} \\
\hline & & R. rickettsii & R. parkeri & R. felis & $R$. bellii & \\
\hline \multirow{10}{*}{ Pirassununga } & E26 & - & - & - & 64 & - \\
\hline & E28 & 256 & 128 & 256 & 64 & - \\
\hline & E30 & 256 & 256 & 256 & 128 & - \\
\hline & E32 & - & - & - & 64 & - \\
\hline & E35 & - & - & - & 64 & - \\
\hline & E36 & - & - & - & 64 & - \\
\hline & E37 & - & - & - & 64 & - \\
\hline & E38 & - & - & - & 64 & - \\
\hline & E41 & 1024 & 512 & 128 & 128 & - \\
\hline & E43 & 512 & 256 & 512 & 512 & - \\
\hline \multirow[t]{3}{*}{ Mogi das Cruzes } & E22 & - & - & - & 64 & - \\
\hline & E24 & 128 & 128 & 128 & 64 & - \\
\hline & E64 & 64 & 128 & 256 & 64 & - \\
\hline Total & 85 & 48 & 48 & 47 & 62 & $\mathbf{0}$ \\
\hline
\end{tabular}

${ }^{1}$ títulos de anticorpos anti-Rickettsia spp verificados nos soros dos animais testados pela RIFI; ${ }^{2}$ resultado da PCR nas amostras de sangue.

Observação: Não constam na tabela, dados de eqüinos não reagentes pela RIFI: 1 indivíduo de Pedreira, 2 de Piracicaba, 9 de São Paulo, 9 de Pirassununga e 2 de Mogi das Cruzes 
APÊNDICE J

Amostras de humanos testadas frente à Rickettsia spp, oriundos do Estado de São Paulo, 2006

(continua)

\begin{tabular}{|c|c|c|c|c|c|c|}
\hline \multirow{2}{*}{ Cidade } & \multirow{2}{*}{ Humano } & \multicolumn{4}{|c|}{ RIFI $^{1}$} & \multirow{2}{*}{$\mathbf{P C R}^{2}$} \\
\hline & & R. rickettsii & R. parkeri & R.felis & R. bellii & \\
\hline \multirow[t]{8}{*}{ Pedreira } & H1 & 128 & 128 & 256 & 128 & - \\
\hline & H17 & 512 & 256 & 64 & - & - \\
\hline & H56 & 128 & 128 & 64 & 64 & - \\
\hline & H61 & 512 & 256 & 256 & 256 & - \\
\hline & H68 & 1024 & 512 & 512 & 512 & - \\
\hline & H74 & 128 & 64 & 64 & - & - \\
\hline & $\mathrm{H} 75$ & 256 & 64 & 64 & - & - \\
\hline & $\mathrm{H} 80$ & 128 & - & 64 & 64 & - \\
\hline \multirow[t]{7}{*}{ Piracicaba } & $\mathrm{H} 28$ & 128 & 64 & 64 & 64 & - \\
\hline & H29 & 512 & 128 & 64 & 128 & - \\
\hline & H31 & 256 & 128 & 64 & 128 & - \\
\hline & $\mathrm{H} 47$ & 128 & - & - & 64 & - \\
\hline & $\mathrm{H} 102$ & 64 & - & - & - & - \\
\hline & H106 & 128 & 128 & 256 & 128 & - \\
\hline & H109 & 128 & 128 & 256 & 64 & - \\
\hline \multirow[t]{10}{*}{ São Paulo } & H178 & 128 & 128 & - & - & - \\
\hline & H187 & 128 & 128 & 128 & - & - \\
\hline & H191 & 128 & 128 & 256 & - & - \\
\hline & H192 & 64 & 256 & 256 & 128 & - \\
\hline & H195 & 128 & 512 & 512 & 64 & - \\
\hline & H206 & 256 & 256 & 512 & 128 & - \\
\hline & $\mathrm{H} 208$ & 128 & 64 & - & 128 & - \\
\hline & $\mathrm{H} 211$ & 64 & 64 & - & - & - \\
\hline & H219 & 128 & 256 & 256 & 512 & - \\
\hline & $\mathrm{H} 231$ & 128 & 128 & - & - & - \\
\hline
\end{tabular}




\section{APÊNDICE J}

Amostras de humanos testadas frente à Rickettsia spp, oriundos do Estado de São Paulo, 2006

(conclusão)

\begin{tabular}{|c|c|c|c|c|c|c|}
\hline \multirow{2}{*}{ Cidade } & \multirow{2}{*}{ Humano } & \multicolumn{4}{|c|}{ RIFI $^{1}$} & \multirow{2}{*}{$\mathbf{P C R}^{2}$} \\
\hline & & R. rickettsii & R. parkeri & R. felis & R. bellii & \\
\hline \multirow[t]{6}{*}{ Pirassununga } & H141 & 512 & 1024 & 64 & - & - \\
\hline & H147 & - & - & 64 & 64 & - \\
\hline & H161 & 128 & 256 & 64 & 512 & - \\
\hline & $\mathrm{H} 163$ & 64 & 128 & - & - & - \\
\hline & H164 & 128 & 128 & 64 & - & - \\
\hline & H166 & 256 & 256 & 64 & 256 & - \\
\hline \multirow[t]{4}{*}{ Mogi das Cruzes } & H88 & 512 & 512 & 512 & 128 & - \\
\hline & H89 & 256 & 256 & 128 & 256 & - \\
\hline & H94 & 64 & 64 & 64 & 64 & - \\
\hline & H96 & 64 & 256 & 128 & 128 & - \\
\hline Total & 238 & 34 & 32 & 28 & 23 & $\mathbf{0}$ \\
\hline
\end{tabular}

${ }^{1}$ títulos de anticorpos anti-Rickettsia spp verificados nos soros dos humanos testados pela RIFI; ${ }^{2}$ resultado da PCR nas amostras de sangue.

Observação: Não constam na tabela, dados de humanos não reagentes pela RIFI: 44 indivíduos de Pedreira, 62 de Piracicaba, 59 de São Paulo, 22 de Pirassununga e 17 de Mogi das Cruzes 